\title{
A Preliminary Classification of Plant Communities in the Central Parkland Natural Sub-Region of Alberta.
}




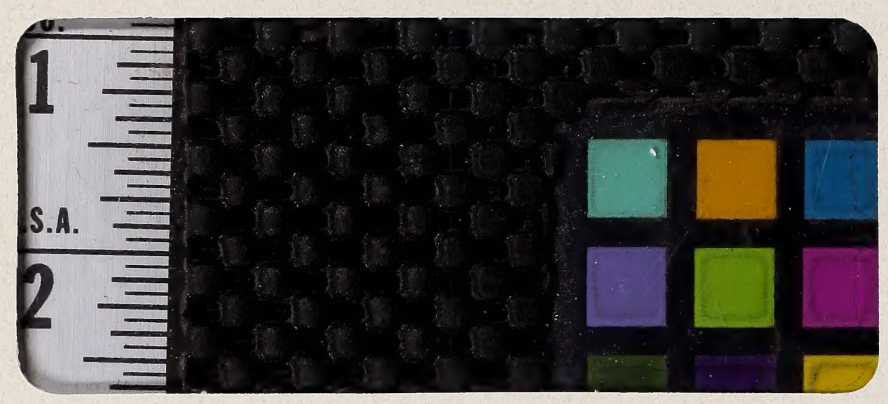




\title{
A Preliminary Classification of Plant Communities in the Central Parkland Natural Sub-Region of Alberta.
}

\author{
Prepared for: \\ Alberta Sustainable Resource Development \\ Public Lands Division \\ Resource Data Branch \\ Edmonton, Alberta \\ Prepared by: \\ Matthew Wheatley \\ and \\ Jerry Bentz \\ Geowest Environmental Consultants Ltd. \\ Suite $2034208-97^{\text {th }}$ Street \\ Edmonton, Alberta, T5K 2J6
}

February 2002 



\section{TABLE OF CONTENTS}

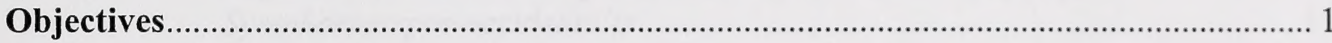

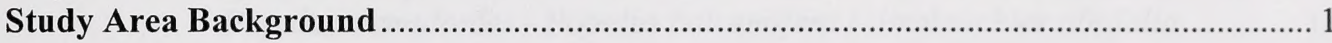

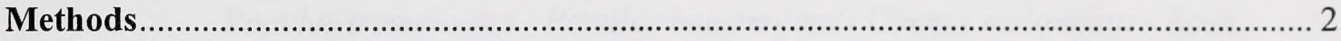

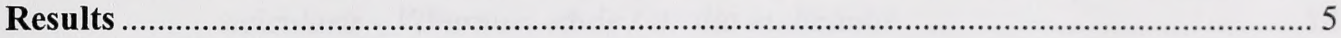

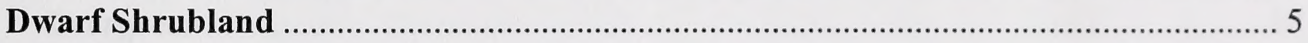

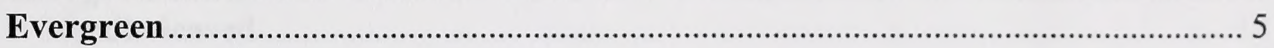

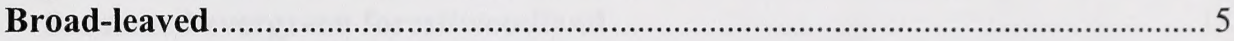

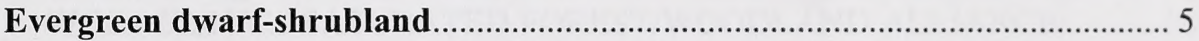

ARCTOSTAPHYLOS UVA-URSI DWARF-SHRUBLAND ALLIANCE............ 5

Arctostaphylos $u v a-u r s i$................................................................................. 5

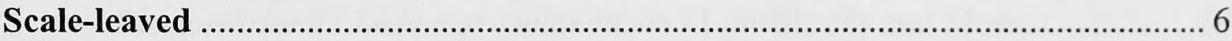

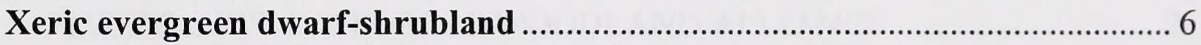

JUNIPERUS HORIZONTALIS DWARF-SHRUBLAND ALLIANCE ............... 6

Juniperus horizontalis.............................................................................. 6

Juniperus horizontalis - Selaginella densa - Calamovilfa longifolia ............... 7

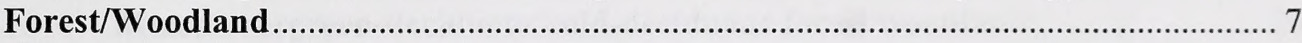

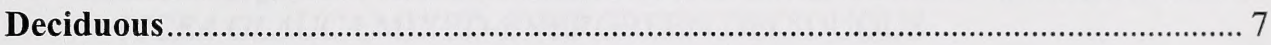

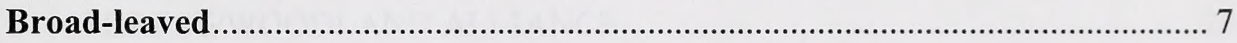

Intermittently flooded cold-deciduous forest/woodland ................................. 7

ALUNUS TENUIFOLIA FOREST/WOODLAND ALLIANCE ......................... 8

Alnus tenuifolia - Salix discolor / Lonicera involucrata - Cornus stolonifera -

Ribes hudsonianum / Plagiomnium cuspidatum ............................................ 8

Cold-deciduous forest/woodland ................................................................. 8

ACER NEGUNDO FOREST/WOODLAND ALLIANCE................................. 8

Acer negundo / Prunus virginiana ....................................................................... 8

BETULA NEOALASKANA - POPULUS BALSAMIFERA

FOREST/WOODLAND ALLIANCE ........................................................... 9

Betula neoalaskana - Populus balsamifera / Cornus stolonifera /

Calamagrostis canadensis ......................................................................... 9

POPULUS BALSAMIFERA FOREST/WOODLAND ALLIANCE .................. 10

Populus balsamifera / Salix discolor - (Betula occidentalis) .......................... 10

Populus balsamifera / Salix petiolaris ........................................................ 10

Populus balsamifera / Viburnum opulus - Cornus stolonifera / Aralia

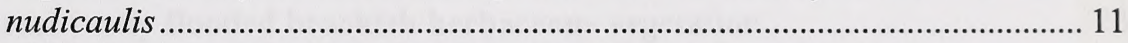

POPULUS TREMULIODES FOREST/WOODLAND ALLIANCE .................. 11

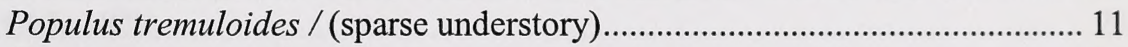

Populus tremuloides / Corylus cornuta / Low Shrubs and Herbs .................. 12

Populus tremuloides / Prunus virginiana - (Shrub) / Low Herb...................... 13

Populus tremuloides / Prunus virginiana / Solidago canadensis ................... 14

Populus tremuloides / Rosa acicularis - Rubus idaeus................................. 15

Populus tremuloides / Symphoricarpos occidentalis / Herbs ......................... 16

Populus tremuloides / Viola adunca - Orthilia secunda ................................. 16 
Digitized by the Internet Archive in 2015

https://archive.org/details/preliminaryclass00whea 
POPULUS TREMULOIDES - POPULUS BALSAMIFERA

FOREST/WOODLAND ALLIANCE

Populus tremuloides - Populus balsamifera - Betula papyrifera I

Symphoricarpos occidentalis

Populus tremuloides - Populus balsamifera / Amelanchier alnifolia .....

Populus tremuloides - Populus balsamifera / Cornus stolonifera - Rosa acicularis - Viburnum edule / Aralia nudicaulis.

Evergreen

Needle-leaved

Saturated evergreen forest/woodland ................................................................ 18

PICEA GLAUCA SATURATED FOREST/WOODLAND ALLIANCE .......... 18

Picea glauca / Cornus stolonifera / Climacium dendroides ............................ 18

PICEA MARIANA SATURATED FOREST/WOODLAND ALLIANCE......... 19

Picea mariana / Ledum groenlandicum / Low Shrubs and Moss..................... 19

PINUS BANKSIANA FOREST/WOODLAND ALLIANCE............................... 20

Pinus banksiana / Arctostaphylos uva-ursi..................................................... 20

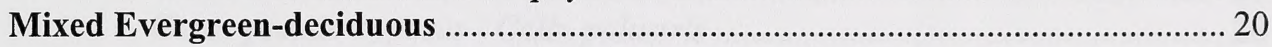

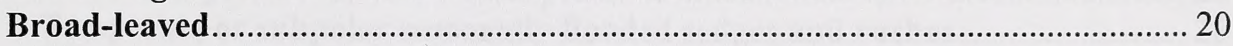

Mixed-evergreen-deciduous cold-deciduous forest/woodland ............................ 20

PICEA GLAUCA MIXED-EVERGREEN DECIDUOUS

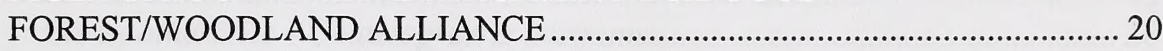

Picea glauca - Populus tremuloides - Populus balsamifera / (shrubs and herbs).

POPULUS TREMULOIDES MIXED-EVERGREEN DECIDUOUS

FOREST/WOODLAND ALLIANCE

Populus tremuloides - Populus balsamifera - Picea glauca / Rubus idaeus .. 21

Populus tremuloides (Picea glauca) / Aralia nudicaulis / Cornus canadensis

Herbaceous

Annual

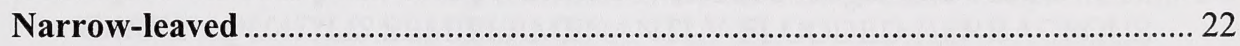

Riparian herbaceous vegetation ................................................................... 22

SENECIO CONGESTUS HERBACEOUS ALLIANCE ................................... 22

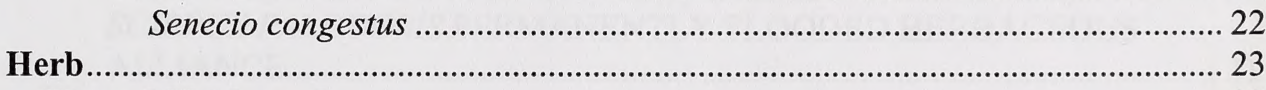

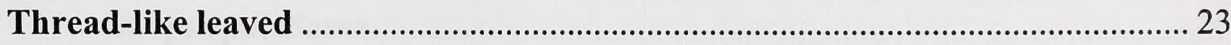

Intermittently flooded brackish herbaceous vegetation .................................... 23 RUPPIA MARITIMA INTERMITTENTLY FLOODED HERBACEOUS

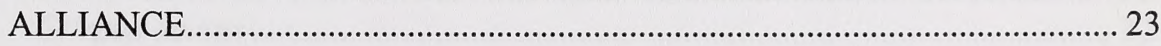

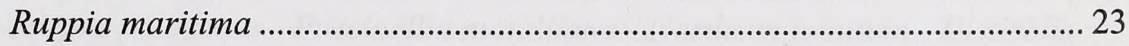

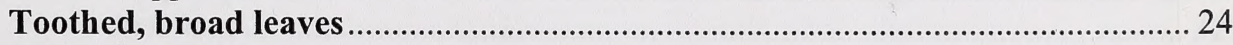

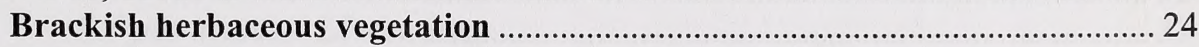

POTENTILLA ANSERINA HERBACEOUS ALLIANCE ................................. 24

Potentilla anserina - Distichlis stricta .......................................................... 24

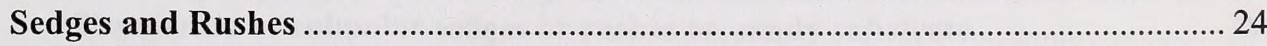

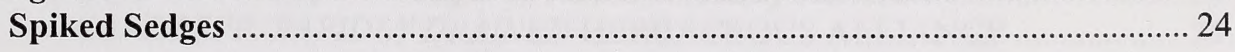




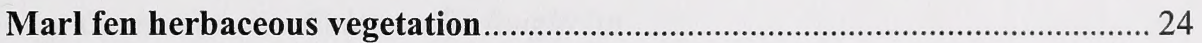

ELEOCHARIS QUINQUEFOLIA HERBACEOUS ALLIANCE ...................... 24

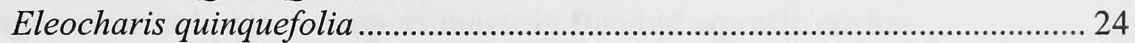

Temperate or subpolar sedge grassland ........................................................ 25

CAREX SPP. SEDGE GRASSLAND ALLIANCE............................................ 25

Carex group - Calamovilfa longifolia ............................................................ 25

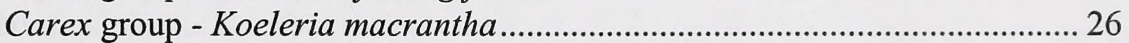

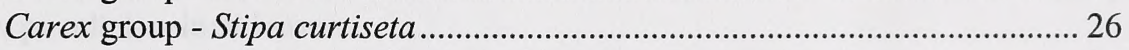

Temperate or subpolar intermittently flooded sedges and rushes ................... 27

CAREX ATHERODES INTERMITTENTLY FLOODED HERBACEOUS

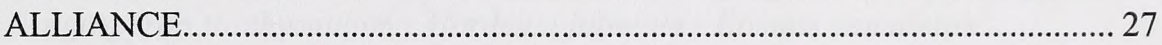

Carex atherodes - Carex rostrata ............................................................ 27

Temperate or subpolar permanently-flooded sedges and rushes..................... 27

CAREX SPP. PERMANENTLY FLOODED HERBACEOUS ALLIANCE .... 27

Carex atherodes - Scolochloa festucacea - Eleocharis palustris - Typha

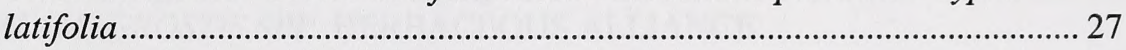

Carex pseudo-cyperus - Calla palustris ....................................................... 28

Temperate or subpolar seasonally flooded sedges and rushes ......................... 28

CAREX ATHERODES SEASONALLY-FLOODED HERBACEOUS

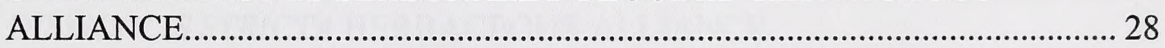

Carex atherodes - Calamagrostis inexpansa ................................................... 28

Carex atherodes - Scolochloa festucacea - Poa palustris - Cirsium arvense. 29 ELEOCHARIS PALUSTRIS SEASONALLY FLOODED HERBACEOUS

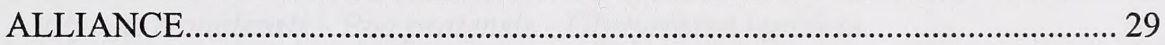

Eleocharis palustris ................................................................................. 29

Temperate or subpolar temporarily flooded sedges and rushes ...................... 30

CAREX ATHERODES TEMPORARILY FLOODED HERBACEOUS

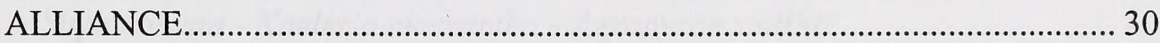

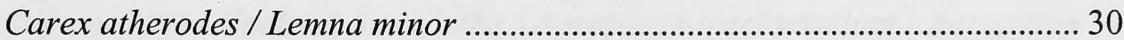

Temperate or subpolar semipermenantly flooded sedges and rushes ............... 30 CAREX AQUATILIS SEMIPERMENANTLY FLOODED HERBACEOUS

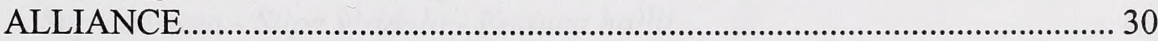

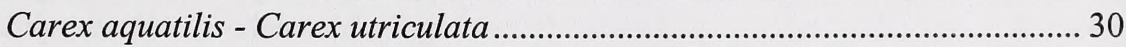

SCIRPUS PALUDOSIS PERMANENTLY FLOODED HERBACEOUS

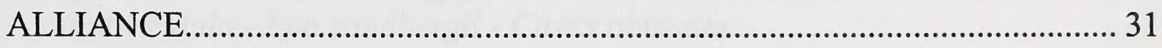

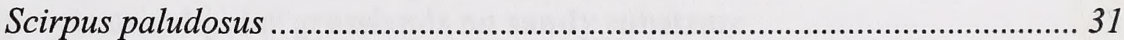

SCIRPUS SPP. SEMIPERMENANTLY FLOODED HERBACEOUS

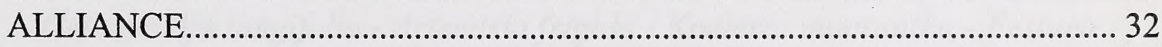

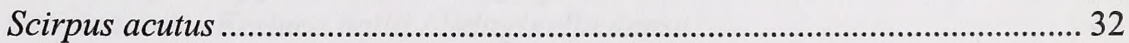

Scirpus paludosus - Puccinellia nuttalliana - Hordeum jubatum - Distichlis

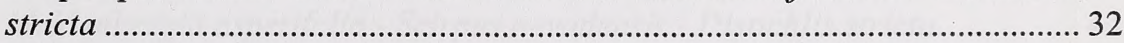

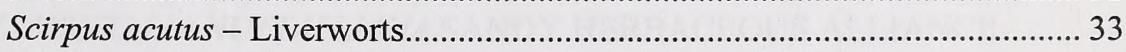

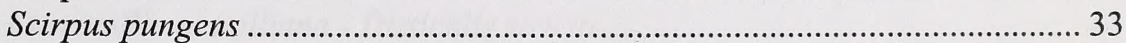

Scirpus pungens - Hordeum jubatum - Puccinellia nuttalliana ...................... 33

Temperate or subpolar sedges or rushes on sandy substrate ………………....... 34

CAREX SPP. RAPIDLY DRAINED HERBACEOUS ALLIANCE .................... 34 
Carex siccata - Calamovilfa longifolia .......................................................... 34

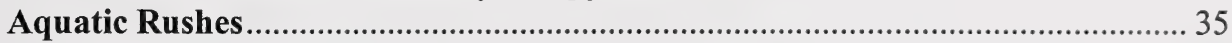

Temperate or subpolar semipermanently flooded aquatic rushes................... 35

TYPHA LATIFOLIA SEMIPERMANENTLY FLOODED HERBACEOUS

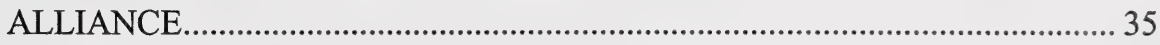

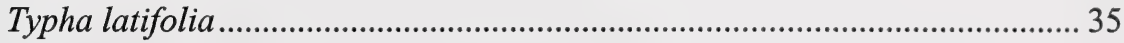

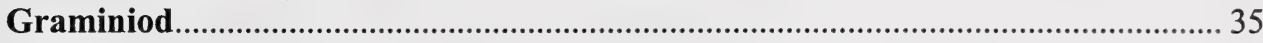

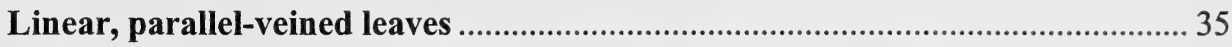

Temperate or subpolar grasslands ................................................................. 35

AGROPYRON TRACHYCAULUM HERBACEOUS ALLIANCE ..................... 35

Agropyron trachycaulum - Hordeum jubatum - Elymus canadense................ 35

AGROSTIS SCABRA HERBACEOUS ALLIANCE …………………………..... 36

Agrostis scabra - Achillea millefolium - Antennaria parvifolia ....................... 36

BOUTELOUA GRACILIS HERBACEOUS ALLIANCE ...................................... 36

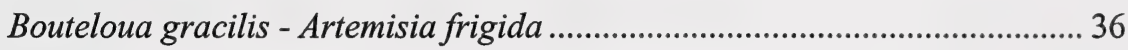

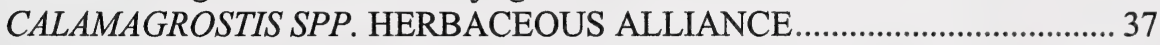

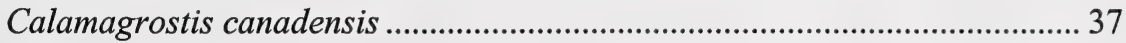

Calamagrostis stricta - Juncus balticus - Potentilla anserina - Aster hesperius

DISTICHLIS STRICTA HERBACEOUS ALLIANCE............................. 37

Distichlis stricta

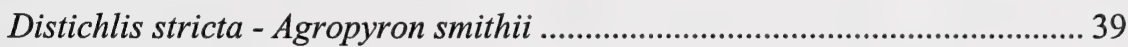

ELYMUS CANADENSIS HERBACEOUS ALLIANCE ........................................ 39

Elymus canadensis - Poa pratensis - Glycyrrhiza lepidota .............................. 39

KOELERIA MACRANTHA HERBACEOUS ALLIANCE ................................ 40

Koeleria macrantha - Agropyron smithii.......................................................... 40

STIPA SPP. HERBACEOUS ALLIANCE............................................................ 40

Stipa comata - Koeleria macrantha - Agropyron smithii ................................ 40

Stipa comata - Koeleria macrantha - Agropyron trachycaulum - Agropyron

smithii - Carex obtusata ................................................................................... 41

Stipa comata - Poa sandbergii - Carex obtusata .............................................. 41

Stipa comata - Stipa viridula - Festuca hallii .................................................. 41

Stipa curtiseta - Artemisia frigida ................................................................. 42

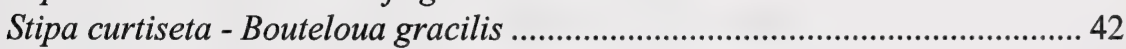

Stipa viridula - Poa sandbergii - Carex obtusata ........................................... 43

Temperate or subpolar grasslands on sandy substrate .....................................4 43

CALAMOVILFA LONGIFOLIA SANDY HERBACEOUS ALLIANCE ........... 43

Calamovilfa longifolia - Artemisia frigida - Koeleria macrantha - Festuca saximontana - Festuca hallii / Selaginella densa ............................................ 43

MUHLENBERGIA ASPERIFOLIA SANDY HERBACEOUS ALLIANCE ..... 44

Muhlenbergia asperifolia - Scirpus nevadensis - Distichlis stricta.................. 44

PUCCINELLIA NUTTALLIANA SANDY HERBACEOUS ALLIANCE .......... 44

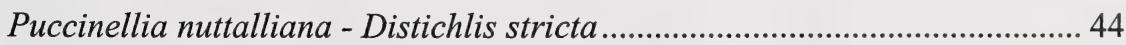

SPARTINA GRACILIS HERBACEOUS ALLIANCE......................................... 45

Spartina gracilis - Agropyron smithii .......................................................... 45

STIPA CURTISETA SANDY HERBACEOUS ALLIANCE .............................. 45 

Stipa curtiseta - Koeleria macrantha - Agropyron trachycaulum / Cladina mitis.....

Temperate or subpolar seasonally flooded grasslands

HORDEUM JUBATUM SEASONALLY FLOODED HERBACEOUS

ALLIANCE.

Hordeum jubatum

PUCCINELLIA NUTTALLIANA HERBACEOUS ALLIANCE.

Puccinellia nuttalliana.

PHALARIS ARUNDINACEA HERBACEOUS ALLIANCE

Phalaris arundinacea - Carex atherodes - Calamagrostis stricta................. 47

Temperate or subpolar intermittently flooded grasslands.

CALAMAGROSTIS INEXPANSA INTERMITTENTLY FLOODED

HERBACEOUS ALLIANCE

Calamagrostis inexpansa - Juncus balticus................................................ 48

Hordeum jubatum - Puccinellia nuttalliana ............................................... 48

Composites

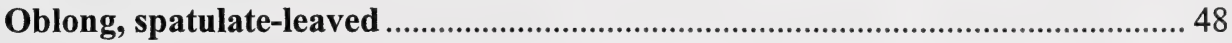

Temperate or subpolar composite grasslands ..................................................49

ANTENNARIA PARVIFOLIA HERBACEOUS ALLIANCE............................ 49

Antennaria parvifolia - Artemisia frigida - Koeleria macrantha ................... 49

Twice-pinnate leaves.

Temperate or subpolar composite grasslands

ARTEMISIA FRIGIDA HERBACEOUS ALLIANCE ....................................... 49

Artemisia frigida / Koeleria macrantha - Carex obtusata ............................ 49

Leaves large, petioled.

Temperate or subpolar permanently flooded composite wetlands ................. 50 POLYGONUM AMPHIBIUM PERMANENTLY FLOODED HERBACEOUS

ALLIANCE............................................................................................. 50

Shrubland

Polygonum amphibium .............................................................................. 50

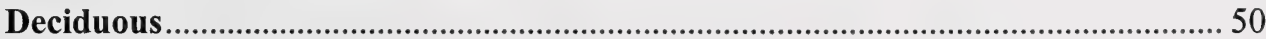

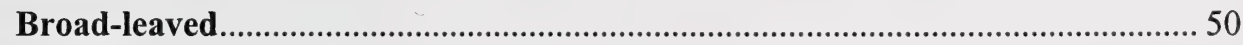

Temperate or subpolar cold-deciduous shrubland ...................................... 50

ELAEAGNUS COMMUTATA SHRUBLAND ALLIANCE ............................ 50

Elaeagnus commutata ............................................................................... 50

Elaeagnus commutata / Symphoricarpos occidentalis - Rosa woodsii / Poa

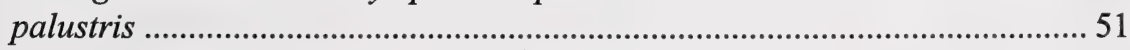

POPULUS TREMULOIDES SHRUBLAND ALLIANCE ............................. 52

Populus tremuloides - Amelanchier alnifolia - Prunus virginiana / Rosa spp.

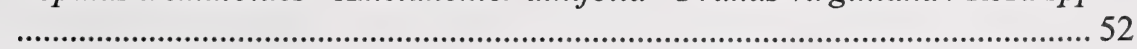

PRUNUS VIRGINIANA SHRUBLAND ALLIANCE................................... 52

Prunus virginiana - Amelanchier alnifolia / Agropyron trachycaulum - Poa

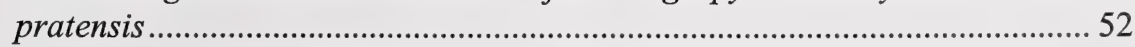

ROSA ACCICULARIS SHRUBLAND ALLIANCE ........................................ 53

Rosa acicularis - (shrub) / Solidago spp .................................................. 53

Rosa acicularis - Rubus idaeus / Lathyrus venosus ..................................... 53 



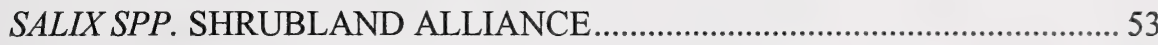

Salix petiolaris / (low shrubs and herbs)........................................................ 53

SYMPHORICARPOS OCCIDENTALIS SHRUBLAND ALLIANCE............... 54

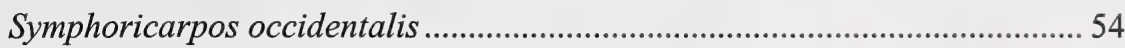

Symphoricarpos occidentalis / Antennaria parvifolia - Festuca hallii............ 55

Temperate or subpolar permanently flooded cold-deciduous shrubland ........56 BETULA PUMILA PERMANENTLY FLOODED SHRUBLAND ALLIANCE

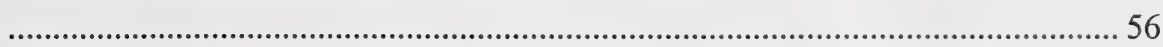

Betula pumila / Carex aquatilis .....................................................................5 56

SALIX PYRIFOLIA PERMANENTLY FLOODED SHRUBLAND ALLIANCE

Salix pyrifolia - Betula neoalaskana / Ledum groenlandicum - Calamagrostis canadensis / Sphagnum warnstorfii .................................................................5 56

Salix pyrifolia / Carex utriculata ..................................................................... 57

Temperate or subpolar semi-permanently flooded cold-deciduous shrubland

SALIX PETIOLARIS SEMI-PERMANENTLY FLOODED SHRUBLAND..... 57

Salix petiolaris - Salix planifolia / Carex utriculata ......................................... 57

Salix petiolaris / Juncus balticus .....................................................................5 57

Temperate or subpolar cold-deciduous shrubland on sandy substrate............58

POPULUS TREMULOIDES SANDY SHRUBLAND ALLIANCE .................. 58

Populus tremuloides / Juniperus horizontalis / Cladina mitis......................... 58

SYMPHORICARPOS OCCIDENTALIS SANDY SHRUBLAND ALLIANCE 58

Sparse

Symphoricarpos occidentalis - Rosa arkansana / Juniperus horizontalis...... 58

Xeric sandy soil

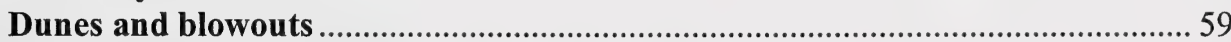

Temperate or subpolar sparse graminoids on sand ......................................... 59

Calamovilfa longifolia - Sporobolus cryptandrus - Koeleria macrantha -

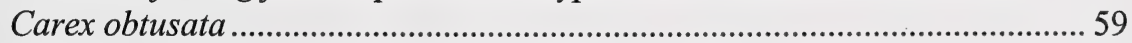

Temperate or subpolar sparse cold-deciduous shrubs on sand.........................59

Populus tremuloides / Juniperus horizontalis ................................................. 59

Populus tremuloides - Prunus virginiana / Juniperus horizontalis / Selaginella

densa

Temperate or subpolar sparse evergreen shrubs on sand ................................... 60

Juniperus horizontalis / (Koeleria macrantha) / Cladina mitis......................... 60

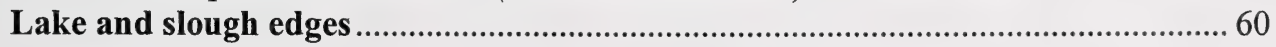

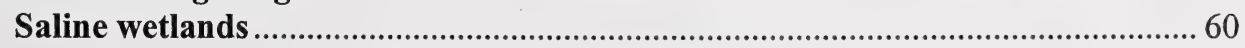

Saline wetland sparse herbaceous vegetation .................................................... 60

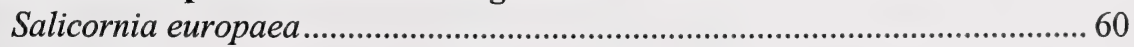

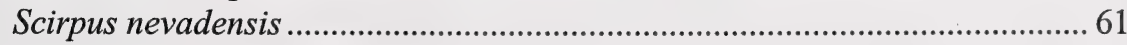

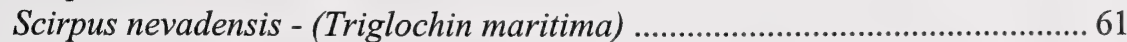

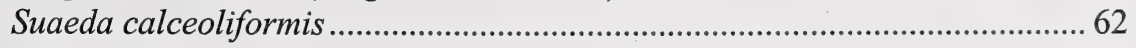

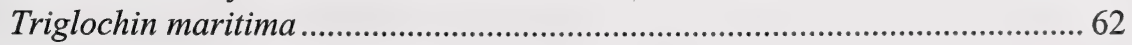

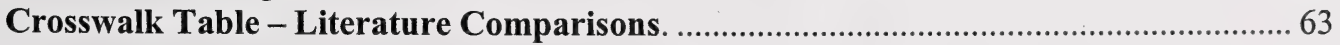

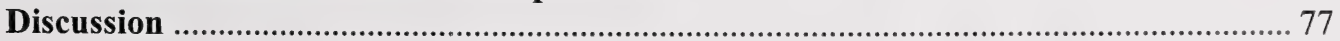





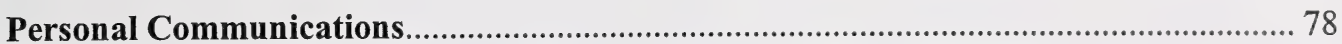

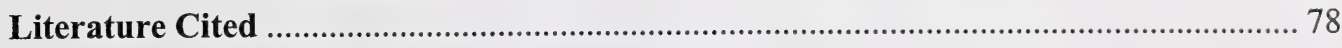





\section{Objectives}

The objective of this report was to produce a synopsis of historical data on Central Parkland natural/near natural plant community types, and to create a preliminary provincial classification of these types. In addition, each community was to be assigned a preliminary provincial conservation rank based on available information or expert opinion, and comparisons with similar plant communities found in adjacent provinces and states were to be made. There was no field component in this process, all conclusions were based on a review and synthesis of the best available information.

The Resource Data Division of Alberta Environment contracted Geowest Environmental Consultants Ltd. to compile available information on plant community types within the Central Parkland natural sub-region of Alberta, excluding Festuca spp., Agropyron spp., and Artemisia cana communities which are included in other reports (Weerstra and Weerstra 1998, Vujnovic and Bentz 2001, and Weerstra 2001, respectively). This initiative is in support of the Alberta Natural Heritage Information Center (ANHIC). ANHIC collects, evaluates and makes available information on elements of natural biodiversity of Alberta, including flora, fauna and natural plant communities. ANHIC develops tracking lists of elements that are considered of high priority because they are considered rare or special in some way. ANHIC's long-term goal is to develop a list of plant community types which occur throughout the province and to attempt to identify community types that require conservation initiatives.

\section{Study Area Background}

\section{Parkland}

The Parkland Region extends from northern Minnesota northeastward through southern Manitoba, central Saskatchewan, and Alberta (Bird 1961). It is also found along the Rocky Mountain Foothills and in the Peace River Area of Alberta, and in Glacier County, Montana (Bird 1961, Lynch 1955). Alberta's Parkland Region can be divided into three natural subregions; the Central, the Foothills, and the Peace River subregions, all part of a landscape classification system consisting of six regions and 20 subregions throughout the province (Alberta Environmental Protection 1994b). The Parkland Natural Region forms a transition zone between the drier grasslands of the plains and the mixedwood and coniferous forests of the Boreal Forest and the Rocky Mountains (Alberta Environmental Protection 1997).

\section{Central Parkland}

The Central Parkland Natural Subregion occurs between the grasslands of southern Alberta and the boreal forest to the north. Its northern boarder runs from Edmonton to the Saskatchewan border, roughly following the North Saskatchewan River, while its southern border arcs from Calgary northeast, just south of Stettler, to the Saskatchewan border. The region is a mixture of vegetation and landforms transitional to the boreal and grassland regions. Surficial deposits include hummocky and ground moraines, glaciolacustrine deposits, coarse outwash, kame moraines, and dune fields (Alberta Environmental Protection 

1997). Associated plant communities in this subregion can include a mixture of grasslands, mixed deciduous and mature aspen forests, saline wetlands, shrublands extending out from forested areas, and sparse communities stabilizing sand dune slopes. Most of the natural elements of the Parkland Region are now limited to marginal lands or ecological reserves (e.g. Rumsey and Wainwright). The majority of the region has been permanently altered from pre-settlement conditions primarily by agriculture, oil and gas development, and cattle farming.

This area is highly productive in agriculture and oil and gas production, two industries that are visibly prominent across the subregion's landscape. The Central Parkland is the most densely populated region of the province and the majority of the Parkland's native vegetation has been lost to human development. Between the mid 1800s and present day it is estimated that $85-95 \%$ of the Parkland Region has been lost to cultivation, urbanization, roads and other anthropogenic development (IISD 1994). Despite the historically high human presence the Central Parkland, many native vegetation community types were not adequately documented before they were eliminated or greatly reduced. The area of uncultivated Parkland continues to decline today (Alberta Environmental Protection 1997). Therefore, Alberta Environment has deemed it a priority to compile and organize existing information on native or near-native vegetation communities in the Central Parkland natural subregion.

\section{Methods}

\section{Vegetation Community Information Collection}

Information provided in this report was generated by a literature review. Discussions with researchers familiar with and experienced in sampling vegetation communities within the Central Parkland natural subregion of Alberta were also incorporated. There was no field component to this study.

\section{Community Classification System}

Community classification followed the hierarchical guidelines set forth by Grossman et al. (1998). Community types were grouped first by physiognomic levels, and second by floristic levels. Physiognomic groupings consist of five levels: Class, Subclass, Group, Subgroup, and Formation.

Physiognomic Levels:

Class: Community class is based on the vegetation structure of the dominant, uppermost life form and contains six different levels:

1. Forest/Woodland - Trees with crowns overlapping (25-100\% cover)

2. Shrubland - Shrubs generally $>0.5 \mathrm{~m}$ tall forming $>25 \%$ cover

3. Dwarf-Shrubland - Shrubs $<0.5 \mathrm{~m}$ tall forming $>25 \%$ cover

4. Herbaceous - Graminiods, ferns and forbs dominant

5. Nonvascular - bryophytes, lichens and algae dominant

6. Sparse-Abiotic substrate dominant 

Subclass: Community subclass is based upon the growth-form characteristics of the dominant life form, predominantly leaf phenology for classes 1-3 (e.g. evergreen, deciduous, mixed evergreen/deciduous), persistence for class 4 (perennial, annual), and substrate characteristics for class 6 (e.g. rocks, sand, exposed lakeshore). Class 5 is not represented in this report.

Group: Community groups are defined based on leaf characters (broad leaf, needle, scale, etc.). The presence of woody strata separates groups in the Herbaceous and Nonvascular classes, and Sparse vegetation communities are separated on the basis of topographic position (shores, cliffs, etc.).

Subgroup: Community subgroups divide each group into either a Natural/Seminatural or a Cultural subgroup. All plant communities discussed in this report are in the Natural/Seminatural subgroup.

Formation: Community formations represent vegetation types that share a definite physiognomy or structure within broadly defined environmental factors, landscape positions, or hydrological regimes (e.g. Temperate or subpolar cold-deciduous shrubland).

Floristic Levels:

Two floristic levels are used: the Alliance and the Association. Both are based on the dominant species in the community.

Alliance: The alliance is a physiognomically uniform group of plant associations (see below) sharing one or more diagnostic species, which as a rule are found in the uppermost stratum of the vegetation (Grossman et al. 1998).

Association: The association is the lowest level of the hierarchy and is defined as a plant community type of definite floristic composition, uniform habitat conditions, and uniform physiognomy (Grossman et al. 1998). Nomenclature at this level is based on the diagnostic species. Species occurring in the uppermost strata are listed first (separated by a hyphen if in the same strata, and a slash if in separate strata) followed successively by those occurring in lower levels. Within the same stratum, the order of species names generally reflects decreasing levels of dominance or constancy (Grossman et al. 1998).

\section{Estimating Conservation Preliminary Ranks}

Each community was given a preliminary provincial conservation rank based on available occurrence or abundance information, or expert opinion. The ranking system used is based on The Nature Conservancy's species ranking system (Grossman et al. 1994). The two major criteria used in ranking communities are the total number of occurrences and the total acreage or area of each community. Trends in range expansion and immediate threats to 


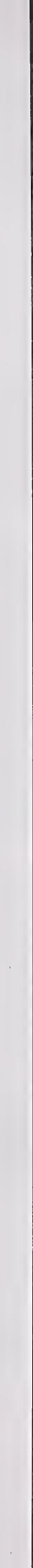


community persistence are considered in ranking as well. Preliminary Ranks range from S1 to S5, from rare or threatened to widespread, respectively (Table 1).

The information used as rational behind selected ranks was provided from both the published literature (if available) and professional opinion. The ranks generated using these methods are highly subjective. Most published community-level vegetation descriptions applicable to the Central Parkland Natural Subregion of Alberta are qualitative and without abundance measurements, and professional opinion in the absence of empirical support is tenuous at best. The rankings provided in this report are as such considered preliminary and should be consistently under review as new, quantitative information is acquired.

Table 1. Provincial conservation ranks and definitions.

\begin{tabular}{|c|c|}
\hline $\begin{array}{l}\text { Preliminary } \\
\text { Rank }\end{array}$ & Criteria \\
\hline S1 & $\begin{array}{l}\text { Five or fewer occurrences, very few remaining hectares, especially } \\
\text { vulnerable to extirpation. }\end{array}$ \\
\hline $\mathrm{S} 2$ & $\begin{array}{l}\text { Six to } 20 \text { occurrences, few remaining hectares, vulnerable to } \\
\text { extirpation throughout its range. }\end{array}$ \\
\hline $\mathrm{S} 3$ & $\begin{array}{l}21 \text { to } 100 \text { occurrences; may be rare and local throughout its range or } \\
\text { found locally, even abundantly, in a restricted range, or vulnerable to } \\
\text { extirpation throughout it range because of some specific factor. }\end{array}$ \\
\hline S4 & $\begin{array}{l}\text { Uncommon, but not rare, although it may be quite rare in parts of its } \\
\text { range, especially at the periphery; apparently not vulnerable in most } \\
\text { of its range. }\end{array}$ \\
\hline S5 & $\begin{array}{l}\text { Common, widespread and abundant provincially; although it may be } \\
\text { quite rare in parts of its range, especially at the periphery; not } \\
\text { vulnerable in most of its range. }\end{array}$ \\
\hline SU & Not able to rank; status is uncertain. \\
\hline SH & $\begin{array}{l}\text { Historic; presumed eliminated in the province with little or no } \\
\text { likelihood it will be rediscovered; there may be potential for } \\
\text { restoration. }\end{array}$ \\
\hline SX & $\begin{array}{l}\text { Believed to be eliminated throughout the province with virtually no } \\
\text { likelihood that it will be rediscovered; no restoration potential due to } \\
\text { extinction of dominant or characteristic species. }\end{array}$ \\
\hline SP & Potentially exists; further documentation required. \\
\hline $\mathrm{S} ?$ & Element is not yet ranked. \\
\hline
\end{tabular}

Where information was available, plant communities from the Central Parkland of Alberta were compared with any similar communities found within the subregion, in other regions of the province, or from other provinces and states. 
For plant communities containing one or a combination of the following ranks; S1, S2, S3, or SU, an Element Characterization Abstract was completed in a format provided by ANHIC. The abstract format included scientific and common name, physiognomic class, range and distribution information, environmental description, vegetation description, proposed conservation rank and justification, general comments and relevant bibliographic references.

\title{
Results
}

\section{Overview}

A total of 106 plant communities occurring and described within the Central Parkland natural subregion were derived from the literature, unpublished data and expert opinion. The majority of the communities were ranked S5 or SU. Community types included representatives from all classes except Nonvascular. They are presented below by major physiognomic level.

\section{Dwarf Shrubland \\ Evergreen \\ Broad-leaved

\author{
Evergreen dwarf-shrubland
}

\section{ARCTOSTAPHYLOS UVA-URSI DWARF-SHRUBLAND ALLIANCE}

\author{
Arctostaphylos uva-ursi \\ Common Bearberry \\ Preliminary Rank: S5
}

In the Central Parkland, this community type is described from one site in the Dillberry Lake Provincial Park area of Alberta by Meijer and Karpuk (1999). This community occurs on Orthic Regosolic soils where drainage is rapid, moisture conditions are xeric, and nutrients are submesotrophic. It forms communities on sandy, upland plains in parkland regions in areas where very little soil formation is evident and forbs comprise a higher cover than grass. Common associates for this Parkland community include Juniperus horizontalis, Heterotheca villosa, Solidago missouriensis, Artemisia frigida, Artemisia campestris, Calamovilfa longifolia and Agropyron dasystachyum. Because this type is only described from one site, an assessment of variability between occurrences in the Central Parkland is not available.

Remphrey et al. (1983) note that the occurrence of $A$. uva-ursi is common on sand dune areas of sub-boreal regions of Canada. In the southern boreal forests of Saskatchewan and Manitoba, bearberry is characteristic of dry and very dry forests (Moss 1955, Beckingham et al. 1996). This species is 

common in Alberta particularly in the foothills and mountain regions and, when present, often forms extensive, low-growing patches (Moss 1983) which can be considered bearberry communities. However, the status of this species as a community and not an associated understory species in many cases is not clear. More work is needed to clarify its distribution as a community type within the Central Parkland.

Elsewhere, Bearberry is a dominant understory species that grows best in high light situations where it forms a compact and intricate mat (Natureserve 2001). Bearberry forms low-growing communities in open pine forests under Pinus banksiana and Pinus contorta in boreal regions (Moss 1955, Beckingham and Archibald 1996) where it is often an extensive understory associate of conifer forest communities (but is otherwise very similar to the Central Parkland A. uva-ursi type). Douglas and Bliss (1977) describe an alpine $A$. uva-ursi dwarf-shrubland community in the western and eastern Cascade Mountains of Washington State as occurring in coniferous forest and alpine meadows (ranked S3 by The Nature Conservancy). This is an alpine community type that does not occur on a sand substrate, characteristics that differentiate this community from Alberta Central Parkland types.

(Dwarf shrubland)

(Evergreen)

Scale-leaved

Xeric evergreen dwarf-shrubland

JUNIPERUS HORIZONTALIS DWARF-SHRUBLAND ALLIANCE

Juniperus horizontalis

Creeping Juniper

Preliminary Rank: SU

In the Central Parkland, this community has been described from 11 sites in the Dillberry Lake Provincial Park area of Alberta by Meijer and Karpuk (1999). In this subregion it occurs on steep, north-east and south-facing slopes, on well drained, glaciofluvial or eolian sites with Orthic Dark Brown or Orthic Regosolic soils with xeric moisture regimes and submesotrophic nutrient conditions. A sparse association of forbs and grasses can include Heterotheca villosa, Thermopsis rhombifolia, Comandra umbellata, Stipa curtiseta (and comata) and Agropyron trachycaulum. Under steep, dry, and nutrient poor conditions this community grows low and mat-like as it stabilizes exposed mineral soils. An assessment of variability between occurrences for this community in the Central Parkland is not available in the literature.

Juniperus horizontalis is documented from sandy and rocky areas in the foothills and mountains of Alberta (Moss 1983, Johnson et al. 1995) but its 


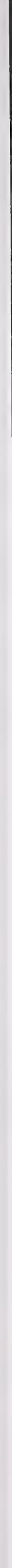


occurrence as a community type in these areas is not clear. Associated species, or lack thereof, differentiate this community from the Juniperus horizontalis - Selaginella densa - Calamovilfa longifolia described by Pearson Timberline Consultants (1993). Creeping juniper is an indictor in a number of grassland or drier coniferous forest habitat types of the northern Great Plains where it occurs most commonly as a co-dominant (Johnston 1987), but is not documented as a community type. Juniperus horizontalis is described as a dominant or an associate of several plant communities in the Central Parkland, but more work is needed to determine its abundance as a community type in this subregion.

\section{Juniperus horizontalis - Selaginella densa - Calamovilfa longifolia Creeping juniper - Prairie selaginella - Sand grass Preliminary Rank: S4}

In the Central Parkland this community type is described from one area in the Wainwright Dunes Ecological Reserve (Pearson Timberline Consultants 1993). This community inhabits dry outwash plains, dune complexes, and kame moraines on grassland areas in the Central Parkland (Pearson Timberline Consultants 1993). It is associated with variable aspect and slope, on rapidly drained areas with xeric to subxeric moisture regimes, and Orthic Regosolic soils. Other shrubs present at lower levels can be Rosa spp. and Prunus virginiana. Artemisia frigida and Festuca hallii can also be present. This community is area-restricted in the Central Parkland to unbroken, sandy areas but it is not considered rare (A.H. Weerstra pers comm.). An assessment of variability between occurrences for this community in the Central Parkland is not available in the literature.

A similar community type, Juniperus horizontalis / Koeleria macranthaArtemisia frigida - Selaginella densa, with similar dominants, similar associated species and the same site conditions is described by Thorpe and Goodwin (1993) from the Manito Sand Hills in Saskatchewan. Festuca hallii is a common associate of this community type. The main difference of this community to the one described above is the presence of Koeleria macrantha as a dominant. There is no available assessment of the constancy of this species as a dominant for this community type, a characteristic that could differentiate these as different types. The distribution of this Saskatchewan type is not clear.

\section{Forest/Woodland \\ Deciduous}

\section{Broad-leaved}

\section{Intermittently flooded cold-deciduous forest/woodland}





\title{
ALUNUS TENUIFOLIA FOREST/WOODLAND ALLIANCE
}

\author{
Alnus tenuifolia - Salix discolor / Lonicera involucrata - Cornus stolonifera - Ribes \\ hudsonianum / Plagiomnium cuspidatum \\ River alder - Pussy willow / Bracted honeysuckle - Red osier dogwood - Wild black \\ currant / Woodsy mnium \\ Preliminary Rank: S5
}

Griffiths et al. (1997) describe this community from one area in the northern Central Parkland of Alberta. It is described as an alder swamp dominated by river alder of tree size, under very wet, intermittently flooded conditions, especially on bog margins and along stream channels (Griffiths et al. 1997). Nutrient conditions and soil types for this community are not discussed in the literature. Common associates include Salix discolor (also of tree size), Lonicera involucrata, Cornus stolonifera, Ribes hudsonianum, Caltha palustris, Viola palustris and Calamagrostis canadensis. Moss coverage (Plagiomnium cuspidatum) is extensive. An assessment of variability between occurrences for this community in the Central Parkland is not available in the literature.

Beckingham and Archibald (1996) describe a similar community from the Boreal Region of Alberta as occurring in lower slope, moist areas (the d1.2 horsetail $\mathrm{Pb}-\mathrm{Bw}$ community type). However, it includes Populus balsamifera as a co-dominant species, lacks Lonicera involucrata and the moss component is primarily Brachythecium spp. We have observed this community in riparian areas of the northern Central Parkland and the Boreal Region of Alberta. We do not consider it rare, even though a formal assessment of its provincial abundance is not available.

\section{Cold-deciduous forest/woodland}

\section{ACER NEGUNDO FOREST/WOODLAND ALLIANCE}

\author{
Acer negundo / Prunus virginiana \\ Manitoba Maple / Choke cherry Forest \\ Preliminary Rank: S1S2
}

This community is not formally described in the literature for the Central Parkland of Alberta. However, it is known to occur in coulees and on protected slopes, primarily in the Grassland Natural Region, and extending into the Central Parkland Subregion (Allen 2001). A tall shrub layer of Prunus virginiana is characteristic of undisturbed stands, but can be replaced by a low shrub layer of Symphoricarpos occidentalis with disturbance such as cattle grazing. Soil type, nutrient conditions and moisture conditions are not described for this community. Associated species of undisturbed stands can 
include Carex sprengelii and Glyceria striata, which are replaced by weedy species under disturbance. Because this type has not been formally described, an assessment of variability between occurrences in the Central Parkland is not available.

This community is included in the ANHIC plant community tracking list (Allen 2001). Manitoba Maple is widely planted but uncommon as a native community in Alberta. It is possibly native along streams in south-eastern Alberta (Moss 1983), but restricted to river floodplains in this area. More work is needed to document the locations and extent of this community in the province.

Wallis (1977) describes a riparian Manitoba Maple community in the Dry Mixedgrass Natural Subregion of Alberta known particularly from the South Saskatchewan and Red Deer River valleys. Manitoba Maple is a component of various deciduous forest plant communities in the Great Plains of North America (Hansen and Hoffman 1988), and in Arizona and New Mexico Manitoba Maple is the overstory dominant in several high elevation riparian forests. This species is widespread in riparian and palustrine communities throughout most of the contiguous United States (Little 1979). Natureserve (2001) provides information only on a riparian floodplain Acer negundo / Prunus virginiana community in the western Great Plains of the United States. This community has similar associated species in addition to Prunus virginiana (Rhus trilobata, Symphoricarpos occidentalis, Ribes aureum) but would differ from Central Parkland types in substrate and topographic position (floodplain versus coulee bottoms). Throughout much of the range of Acer negundo there are no described Manitoba Maple communities.

\section{BETULA NEOALASKANA - POPULUS BALSAMIFERA FOREST/WOODLAND ALLIANCE}

\section{Betula neoalaskana - Populus balsamifera / Cornus stolonifera / Calamagrostis canadensis \\ Alaskan Birch - Balsam Poplar / Red osier dogwood / Marsh reed grass Preliminary Rank: SU}

In the Central Parkland, Griffiths and Griffiths (1987a) describe this community from one site near the Sylvan Lake area of Alberta. This community occurs on lower ground where the Populus tremuloides community gives way to a moister forest and Betula neoalaskana and Populus balsamifera become dominant (Griffiths and Griffiths 1987a). Soils, hydrological conditions and nutrient regimes are not discussed. The understory of this forest type is heterogeneous. Common associates include Cornus stolonifera, Rubus idaeus, Ribes oxyacanthoides, Calamagrostis canadensis, Heracleum lanatum and Aralia nudicaulis. Variation in the understory can occur along streams and seepage channels where Alnus 


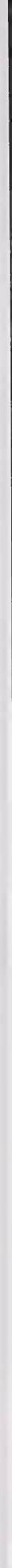


tenuifolia, Caltha palustris, and Carex bebbii, among others can also occur. Because this type is only described from one site, a quantitative assessment of variability between occurrences is not available. Little is documented on Alaskan Birch communities in Alberta, so the distribution and preliminary rank of this community is unknown.

According to Griffiths and Griffiths (1987a), this community is comparable to the "balsam poplar consociation" described by Moss (1932) who did not discriminate based the presence of Betula. It is also similar to the BetuloPopuletum balsamiferae association described from similar, mesic site conditions by Looman (1987b). However, Looman's (1987b) association includes trace amounts of Rhus radicans and Bromus ciliatus. He formed alliances based on the presence of Betula, but makes no reference to association abundance.

\title{
POPULUS BALSAMIFERA FOREST/WOODLAND ALLIANCE
}

\author{
Populus balsamifera / Salix discolor - (Betula occidentalis) \\ Balsam Poplar / Pussy willow - (Water birch) \\ Preliminary Rank: SU
}

In the Central Parkland, Meijer and Karpuk (1999) describe this community type from two sites in the Dillberry Lake Provincial Park area. This "balsam woodland" community occurs on lacustrine deposits adjacent to wetlands (lake perimeters) on wet and nutrient rich substrates with a continuous moisture source (Meijer and Karpuk 1999). Soils for this community range from Rego Gleysols to Orthic and Gleyed Regosols. Common associates include Hordeum jubatum, Salix spp., Juncus balticus, Equisetum spp. and Betula occidentalis. An assessment of variability between occurrences for this community in the Central Parkland is not available from the literature. The distribution and abundance of this community is not clear, and more work is needed to determine its abundance in the province.

This association is similar to the "Populo-Betuletum occidentalis" association as described by Looman (1987a). Similar associates are described for this type but can also include Populus angustifolia at low levels. Looman (1987a) suggests that stands of this association seem to be restricted to southern Alberta, where they occur on sandy soils along rivers, and in some low-lying sand dune areas.

\section{Populus balsamifera / Salix petiolaris}

Balsam poplar / Basket willow

Preliminary Rank: S5

In the Central Parkland, Griffiths et al. (1996) describe this community from seven sites on higher ground near Lister Lake, Alberta. These stands are 

dominated by balsam poplar of approximately 75 years of age, with a shrub layer of Salix petiolaris persisting from an earlier stage of succession. It occupies areas where the water table is at a depth of roughly $1.5 \mathrm{~m}$ and soils are Gleyed Eutric Brunisols. This community can contain significant coverages of Juncus balticus. Griffiths et al. (1996) interpreted this community type as transitional between upland poplar forest and willow shrubbery. Although this type is described from more than one site in the Lister Lake area, an assessment of variability between occurrences is not available. The distribution of this community within the Central Parkland is not well documented, however, this community is considered a common type around lakes and sloughs in the Boreal Forest, Foothills and Parkland Regions of Alberta (G. Griffiths pers comm.).

There are a number of Populus balsamifera - Salix communities described in Beckingham and Archibald (1996) and Beckingham et al. (1996a) but willows are not identified to species making comparisons to these community types tenuous.

Populus balsamifera / Viburnum opulus - Cornus stolonifera / Aralia nudicaulis Balsam poplar / High-bush cranberry / Red osier dogwood / Wild sarsaparilla Preliminary Rank: SU

In the Central Parkland, Fehr (1984) describes this community from two sites in the Wainwright and Ribstone areas of Alberta. This community has a consistently well developed Populus balsamifera layer. Humus layers are also well developed and soils are Dark Brown or Black Chernozems, which usually show some signs of gleying because of a fluctuating water table (Fehr 1984). Shrub cover is roughly $60 \%$ and can include Cornus stolonifera, Populus tremuloides, Rosa acicularis and Symphoricarpos occidentalis. Herb-dwarf shrub coverage averages $70 \%$ and consists of mesophilic or hydrophilic, shade-tolerant species such as Aralia nudicaulis, Thalictrum venulosum, Rubus pubescens and Aster ciliolatus. Balsam Poplar stands are usually located in more mesic locations than Aspen stands, and are commonly located at the bottom of slopes or in depressions surrounding the more hydrophilic willow communities in areas that are moderately well drained (Fehr 1984). An assessment of variability between occurrences for this community is not available from the literature.

Viburnum opulus is not common in Alberta (Moss 1983) and this community type is not well documented in the literature, so more work is required to determine the distribution and abundance of this type.

\section{POPULUS TREMULIODES FOREST/WOODLAND ALLIANCE}

Populus tremuloides / (sparse understory)

Trembling aspen Forest 

Preliminary Rank: S5

In the Central Parkland, this community is described from one site near the Rumsey Ecological Reserve (Fehr 1982) and from one site near Rumsey, Alberta (Wroe 1971). Looman (1987a) also reports this association from the Grassland and Parkland regions of Alberta, but does not discuss occurrence frequency. Little or no understory growth is typical of these young aspen stands ( $<30$ years old) where grassland understory species are shaded out, plant debris accumulates, and the understory becomes sparse and species-poor (Looman 1987a). This community can be found in depressions and on gradually-moderate to steep slopes of northerly, sometimes southerly facing aspects (Fehr 1982). It occurs on sites that are submesic to subhydric with moderately to well drained Black Chernozems and Humic Gleysols. Shrub species can be present but are represented by only a few individuals (e.g. Symphoricarpos occidentalis, Rosa acicularis, Prunus virginiana, and Amelanchier alnifolia) (Looman 1987a). This is considered a stable, slowchanging community (Fehr 1982) forming incomplete rings around willowedged sloughs (Wroe 1971) and ranging in size from 0.02-0.05 ha (Looman 1987a, Wroe 1971). This community is differentiated from other aspen communities by its lack of a significant understory component.

Aspen is found province-wide (Moss 1983) and occurrences with a sparse understory are reported from the Central Parkland and Dry Mixedwood Subregions of Alberta (Looman 1987a). Similar stands further north in Alberta tend to have minor Picea spp. components of $<2 \%$, and considerably higher herb diversity (Beckingham and Archibald 1996).

Populus tremuloides / Corylus cornuta / Low Shrubs and Herbs Trembling aspen / Beaked Hazelnut / Low Shrubs and Herbs Preliminary Rank: S5

This community is described as common from several locations in the Central Parkland (Bork 1993, Coupland 1950, Griffiths and Griffiths 1987b, Griffiths et al. 1997, Looman 1987a, Moss 1932, Polster and Watson 1979, Timoney and Robinson 1998). It is found on upland, steep riparian, and ravine areas and on mesic, well drained sites with Orthic Gray Luvisolic soils (Timoney and Robinson 1998). It is typically found on north or south-facing slopes and is dominated by a mature aspen canopy with a shrub layer consisting primarily of Corylus cornuta at varying heights depending on ungulate browsing pressure (Bork 1993). Given the dense overstory cover, the herb layer tends to be sparse. Associated shrubs and herbs include Rosa acicularis, Amelanchier alnifolia, Viburnum edule, Rubus idaeus, Rubus pubescens, Cornus stolonifera, Symphoricarpos albus, Aralia nudicaulis, Cornus canadensis, Pyrola asarifolia and Galium triflorum. An assessment of variability between occurrences for this community is not available from the literature. 

In the Central Parkland, Griffiths et al. (1997) describe this type as a Populus tremuloides / Corylus cornuta community forming the dominant upland vegetation blanketing most of the higher ground throughout the Blackfoot Recreation Area $26 \mathrm{~km}$ east of Edmonton. Timoney and Robinson (1998) describe the same community from this area. Bork (1993) describes a Populus tremuloides / Corylus cornuta / Aster conspicuous - Disporum trachycarpum - Epilobium angustifolium community and a Populus tremuloides / Corylus cornuta / Oryzopsis asperifolia community from two areas on north facing slopes in Elk Island National Park. From one area on the western edge of the Central Parkland, Griffiths and Griffiths (1987b) describe a Populus tremuloides / Rosa acicularis - Corylus cornuta community. These communities all occur with similar topographic positions and substrate. Canopy and shrub layers are very similar and only show slight variations in herb dominance. They are therefore all considered as the same community in this report. These aspen forests are considered common throughout the Boreal and Parkland Regions of Alberta (Coupland 1950, Griffiths et al. 1997, Moss 1932) and Looman (1987a) suggests this association can be found from northern Alberta to Montana and Manitoba.

This community is similar to the Corylus - Rosa type of Polster and Watson (1979) and the Populus tremuloides / Corylus cornuta / Aralia nudicaulis type of Hardy and Associates (1986), both also from Elk Island National Park. Bork (1993) suggests this community is similar to (unspecified) mature aspen forests found in the Central and Dry Mixedwood Subregions of Alberta. Similarities can also be noted in the "low-bush cranberry Aw" (community d1.3) described by Beckingham and Archibald (1996) from the Boreal Region of Alberta. Moss (1932) called these community types the "aspen consociation", and Looman (1987a) called them the "Alliance Populion tremuloides in the association Corylo-Populetum (forests dominated with aspen having Corylus prominent in the shrub layer)."

\author{
Populus tremuloides / Prunus virginiana - (Shrub) / Low Herb \\ Trembling aspen / Choke cherry (shrub) / Low herb \\ Preliminary Rank: S5
}

Variations of this community are described from several locations in the Central Parkland by Fehr (1984), Meijer and Karpuk (1999) and Pearson Timberline (1993). Populus tremuloides cover averages $41 \%$, and average tree height is $6 \mathrm{~m}$ (Fehr 1984). Cover of the low shrub layer averages $43 \%$, average cover of the herb-dwarf shrub layer is $58 \%$ (Fehr 1984) and bryoid cover is generally low. This community is found on upland eolian and glaciofluvial parent materials on exposed upper slopes where there is no moisture accumulation (Meijer and Karpuk 1999). It is found on dry, sandy outwash plains, dune complexes, interdune depressions, and kame moraines (Pearson Timberline 1993) on the upper portion of dry, north-facing dune 
slopes where moisture conditions are subxeric (Fehr 1984). Soils within this community are poorly developed and can be Ortho Regosols, Rego Dark Brown or Ortho Dark Brown Chernozems (Meijer and Karpuk 1999). Drainage is rapid, and nutrient conditions tend to be submesotrophic. Slope can range from $0-70 \%$ (Pearson Timberline 1993). Other common species can include Populus tremuloides, Amelanchier alnifolia, Symphoricarpos spp., Rosa spp., Juniperus horizontalis, Apocynum androsaemifolium, Agropyron spp., Thalictrum venulosum, Campanula rotundifolia, Lathyrus ochroleucus, Schizachne purpurascens, Carex foenea, Thermopsis rhombifolia, Galium boreale and Smilacina stellata (Fehr 1984, Meijer and Karpuk 1999, Pearson Timberline 1993). The herb-dwarf shrub layer may contain Symphoricarpos occidentalis instead of $S$. albus (Fehr 1984, H. Loonen pers comm.).

Miejer and Karpuk (1999) describe a Populus tremuloides / Populus tremuloides - Prunus virginiana - Amelanchier alnifolia / Juniperus horizontalis - Arctostaphylos uva-ursi community from three areas in Dillberry Lake Provincial Park. Pearson Timberline (1993) describe a Populus tremuloides / Prunus virginiana - Amelanchier alnifolia - Rosa acicularis / Gallium boreale forest type (sometimes lacking one of the shrub components; H. Loonen, pers comm.) from one area in the Wainwright Dunes Ecological Reserve. Fehr (1984) describes a Populus tremuloides / Prunus virginiana - Rosa acicularis community type with a less-developed low shrub layer (10-40\% cover), and a common (H. Loonen, pers comm.) but poorly described Populus tremuloides / Rosa acicularis - Prunus virginiana / Carex siccata community type from the Wainwright area of Alberta. Fehr (1984) also describes a Populus tremuloides / Prunus virginiana / Corylus cornuta Rosa acicularis / Symphoricarpos albus community type from near Wainwright. And finally, Meijer and Karpuk (1999) describe a Populus tremuloides / Amelanchier alnifolia - Prunus virginiana / Symphoricarpos occidentalis community as the "buckbrush associated tall shrub community" noted as common in Dillberry Lake Provincial Park. These communities all have consistent dominants, similar associated species and identical site conditions and are as such all considered the same community type in this report.

Beckingham and Archibald (1996) describe a "low-bush cranberry Aw" community type from the Boreal Region of Alberta with a high component of saskatoon and prickly rose. It has similar dominants to the communities described above, but has moister site conditions and non-sandy substrate. Thorpe and Goodwin (1993) describe a Populus tremuloides / Prunus virginiana - Amelanchier / Gallium boreale community with similar associates and site conditions from the Manito Sand Hills in Saskatchewan.

Populus tremuloides / Prunus virginiana / Solidago canadensis

Trembling aspen / Choke cherry / Canada goldenrod

Preliminary Rank: S5 

This community is described in the Central Parkland from one site near Elk Island National Park (Bork 1993). This community consists of young aspen forests with less developed canopies resulting in a tall forb layer of Solidago canadensis, Aster conspicuous and Lathyrus venosus. Prunus virginiana is a key indicator species for this community type. It can be found in lightly browsed areas with variable topography (mainly crests and south-facing slopes) and variable soil conditions (Bork 1993). Further detail on site conditions is not available. The authors have observed this community type in the Lower Foothills, Central and Dry Mixedwood Natural Subregions of Alberta and, although not considered rare, a formal assessment of provincial abundance is not available.

Beckingham et al. (1996a) describe a similar community type ("hairy wild rye Aw" c3.3) with variation in shrub composition (Rosa acicularis and Amelanchier alnifolia present) and herb composition (Aster conspicuous and Lathyrus spp. absent) from west-central Alberta. Species composition is similar to the Populus tremuloides / Prunus virginiana - (Shrub) / Low Herb community but site conditions are quite different; soils are not sandy and sites are not well drained which would classify this type as separate based on substrate and hydrological regime (see Grossman et al. 1998).

Populus tremuloides / Rosa acicularis - Rubus idaeus

Trembling aspen / Prickly rose - Wild red raspberry

Preliminary Rank: S5

In the Central Parkland, Meijer and Karpuk (1999) describe this community from two sites in Dillberry Lake Provincial Park. It occurs on north or southwest facing slopes, on Orthic Dark Brown Chernozemic soils in areas with rapid drainage, submesic to xeric moisture regimes, and submesotrophic nutrient conditions (Meijer and Karpuk 1999). Associated shrubs are a minor part of this community but if present can include Salix bebbiana, Rosa woodsii and Symphoricarpos occidentalis. Lathyrus ochroleucus, Disporum trachycarpum and Poa spp can also be present. The authors have encountered this community in the Dry and Central Mixedwood subregions of Alberta. Although not considered rare, a formal assessment of provincial abundance is not available. An assessment of variability between occurrences for this community in the Central Parkland is also not available from the literature.

Beckingham and Archibald (1996) describe two similar communities with common canopy and understory dominants from the Boreal Forest Region of Alberta. However, in both cases there is a conifer tree component (either white spruce or lodgepole pine) and variation in the abundance of Rosa acicularis and Rubus idaeus (sometimes not present together). 

Populus tremuloides / Symphoricarpos occidentalis / Herbs

Trembling aspen / Buckbrush / Herbs

Preliminary Rank: S5

In the Central Parkland, this community is described from three sites; two near Dry Island Buffalo Jump Provincial Park (Smith and Kondla 1972, Wroe 1971) and one site near Kinsella, Alberta (Hilton 1970). Wroe (1971) measured tree cover at approximately $90 \%$ and a shrub cover of $S$. occidentalis averaging 69\%. Smith and Kondla (1972) describe the herb layer as well-developed. It is located on north-facing slopes around depressional areas (Wroe 1971) on "knob and kettle" topography where the water table is relatively high (Smith and Kondla 1972). Soils are Carbonated Regosol Humic Gleysols (near depressions), and Black Chernozems (mature stands) (Wroe 1971). Associated species include Rosa woodsii, Amelanchier alnifolia, Aster spp., Actaea rubra, Aralia nudicaulis, Maianthemum canadense, Smilacina stellata, Galium boreale, Calamagrostis inexpansa, Vicia americana, Fragaria virginiana, Epilobium angustifolium, Lathyrus spp., Carex praticola, Viola canadensis and Carex lasiocarpa. An assessment of variability between occurrences for this community is not available from the literature.

Wroe (1971) describes this community as a Populus tremuloides / Symphoricarpos occidentalis stand from one site near Dry Island Buffalo Jump. Similarly, Smith and Kondla (1972) describe a Populus tremuloides / Symphoricarpos occidentalis / Galium boreale community from one site near the same area having similar site conditions and associated species. Lastly, a Populus tremuloides / Symphoricarpos occidentalis / Rubus pubescens community is briefly described as the "Large Poplar" forest community by Hilton (1970) from near Kinsella, Alberta with identical site conditions and associated species. As such, these are all considered the same community type in this report. This community appears similar to the Poplar Association described by Moss (1932) in central Alberta. We have also observed these forest types in the Central and Dry Mixedwood Natural Subregions of Alberta. Although we do not consider them rare, there is no reliable assessment of their overall abundance.

\section{Populus tremuloides / Viola adunca - Orthilia secunda}

Trembling aspen / Early blue violet - One-sided wintergreen

Preliminary Rank: SU

In the Central Parkland, this community is described by Anderson (1972) from one site near Kinsella, Alberta. He called it the "large poplar community", where the average age of aspen trees is roughly 30 years with a herb community dominated by shade tolerant species. Soil, moisture and nutrient conditions are not discussed and the community description is brief. This community occurs at a lower elevation than the poorly described "small 

poplar community" mentioned by Hilton (1970) which contains Populus tremuloides but has an understory (structure and dominance not clear) of Symphoricarpos occidentalis, Rosa woodsii, Rosa acicularis and Rubus strigosus. There are no other records of this community type in the literature, and no mention of community abundance. Because this type is only described from one site, an assessment of variability between occurrences in the Central Parkland is not available.

\section{POPULUS TREMULOIDES - POPULUS BALSAMIFERA FOREST/WOODLAND ALLIANCE}

Populus tremuloides - Populus balsamifera - Betula papyrifera / Symphoricarpos occidentalis

Trembling aspen - Balsam Poplar - Paper birch / Buckbrush Preliminary Rank: SU

This community is described briefly by Smith and Kondla (1972) from one site near Dry Island Buffalo Jump. The dominant species are mentioned but there is no structural description of the strata within this community type. It is frequent along streams and riverbanks where the substrate is usually sand with little or no soil development. Moisture, nutrient and other site conditions are not discussed. Understory shrubs appear to be poorly developed but can also include Amelanchier alnifolia, Prunus spp. and Lonicera involucrata at trace amounts. Because this type is only described from one site, an assessment of variability between occurrences in the Central Parkland is not available. We have observed communities with similar species composition but different site conditions in the northern Central Parkland, Dry Mixedwood and Central Mixedwood subregions of Alberta, but more work is needed to determine the provincial abundance of this community occurring on a sandy substrate.

\section{Populus tremuloides - Populus balsamifera / Amelanchier alnifolia \\ Trembling aspen - Balsam Poplar / Saskatoon \\ Preliminary Rank: S5}

In the Central Parkland, this community is described from one site near Sylvan Lake, Alberta by Griffiths and Griffiths (1987a). This community is an upland forest with dense shrubs, and a highly diverse herb layer without dominants. Moisture, nutrient and other site conditions are not discussed. Associated shrubs include Viburnum edule and Prunus virginiana. The most prominent herbs include Maianthemum canadense, Viola canadensis and Aralia nudicaulis. Because this type is only described from one site, an assessment of variability between occurrences in the Central Parkland is not available.

This association can be found along the southern fringes of the boreal forest (Beckingham and Archibald 1996), and occurs in many parks and natural 

areas in the Edmonton region (Griffiths and Griffiths 1987a). Though not considered rare, the provincial abundance of this community type requires clarification.

Populus tremuloides - Populus balsamifera / Cornus stolonifera - Rosa acicularis Viburnum edule / Aralia nudicaulis

Trembling aspen - Balsam poplar / Red osier dogwood - Prickly rose - Lowbush cranberry / Wild sarsaparilla

Preliminary Rank: S5

In the Central Parkland, Pearson Timberline (1993) describes this community from one location in the Wainwright Dunes Ecological Reserve. This forest type is found in wet, eolian depressions with Gleyed, Dark Brown and Dark Grey Chernozemic soils. It occurs in hygric to subhygric areas with imperfect drainage, variable aspect, and slopes ranging from $0-5 \%$. Associated species besides dominants are not discussed. It is can also be found around lakes and wet areas in the northern Central Parkland, Dry Mixedwood and Central Mixedwood Subregions of Alberta (personal observation). Beckingham and Archibald (1996) describe a similar community (the horsetail Pb-Aw f1.1) which only differs in that it contains components of Salix spp, Alnus spp. and Equisetum spp. all at covers of $<10 \%$. Because this type is only described from one site, an assessment of variability between occurrences is not available.

(Forest/Woodland)

Evergreen

\section{Needle-leaved}

\section{Saturated evergreen forest/woodland}

\section{PICEA GLAUCA SATURATED FOREST/WOODLAND ALLIANCE}

\section{Picea glauca / Cornus stolonifera / Climacium dendroides}

White spruce / Red osier dogwood / Common tree moss

Preliminary Rank: S5

Griffiths et al. (1997) describe this community from one site in the Blackfoot Recreation Area of Alberta. It can be found on lower slope positions in depressional sites. Site conditions and associated species are not discussed. This community is classified as a white spruce swamp by Griffiths $e t$ al. (1997) and can contain Moneses uniflora considered locally rare. We have observed this forest type in the Upper Foothills, Dry Mixedwood and Central Mixedwood Natural Subregions of Alberta and consider it a common spruce habitat, however, a formal provincial abundance assessment of this community type is not available. Because this type is only described from one site, an assessment of variability between occurrences is not available. 

Similar communities are described by Beckingham and Archibald (1996) from the Boreal Region of Alberta (the dogwood Sw e3.1 community). These boreal communities can contain aspen and balsam poplar as minor canopy components, and have Rosa acicularis, Viburnum edule, Linnaea borealis and Rubus idaeus as understory associates.

\section{PICEA MARIANA SATURATED FOREST/WOODLAND ALLIANCE}

Picea mariana / Ledum groenlandicum / Low Shrubs and Moss

Black spruce / Labrador tea / Low Shrubs and Moss

Preliminary Rank: S5

This community is considered a common black spruce bog and is described from two sites in the Central Parkland (Griffiths and Griffiths 1987b, Griffiths et al. 1997). This type typically consists of an open spruce canopy with Ledum groenlandicum less than $50 \mathrm{~cm}$ in height on an extensively mosscovered substrate. It can be found in wetlands or perched depressions on higher ground. Site conditions are not discussed for these parkland communities but are commonly subhydric to hydric. The shrub layer is dominated by Ledum groenlandicum but can also include Vaccinium vitisidaea. Herb coverage is often sparse but can include Rubus chamaemorus. Moss and lichen cover is extensive and includes Pleurozium schreberi, Cladina rangiferina, Hylocomium splendens, Ptilium crista-castrensis and Sphagnum spp.

Two occurrences of this community type are described from the Central Parkland with identical site conditions and associated species. Griffiths and Griffiths (1987b) describe a Picea mariana / Ledum groenlandicum Vaccinium vitis-idaea black spruce bog community from the Bilby Natural Area near Onoway, Alberta. Griffiths et al. (1997) describe a Picea mariana / Ledum groenlandicum / Pleurozium schreberi community from the Blackfoot Recreation Area. Given the similarities in topographic position and associated species, these are considered the same community type in this report. An assessment of species variability or constancy between occurrences for this community in the Central Parkland is not available from the literature.

This forest community can be considered common in the northern Central Parkland (Griffiths and Griffiths 1987b, Griffiths et al. 1997), and is described in the boreal regions of Saskatchewan (Acton et al. 1998) and the conifer forests of Michigan (Marshner 1974). This forest type can be observed throughout the Boreal and Foothills Regions of Alberta (e.g. the "treed bog" communities of Beckingham and Archibald 1996 and Beckingham et al. 1996). 



\section{PINUS BANKSIANA FOREST/WOODLAND ALLIANCE}

Pinus banksiana / Arctostaphylos uva-ursi

Jack pine / Bearberry

Preliminary Rank: S5

This typical jack pine community is described from one location in the northern Central Parkland by Griffiths and Griffiths (1987b). Topographic and site conditions are not discussed but this community typically occurs on upland, sandy areas with rapid drainage. Associated species for this Central Parkland type include Vaccinium myrtilloides, Aster laevis, Oxytropis deflexa and Solidago spathulata. Although not formally assessed for abundance, this community is not considered rare and can be observed frequently from the north Central Parkland well into the Dry and Central Mixedwood Regions of Alberta.

Beckingham and Archibald (1996) describe several Pinus banksiana / Arctostaphylos uva-ursi ("bearberry Pj") communities from the Boreal Region of Alberta with similar associates consisting of Vaccinium myrtilloides (and vitis-idaea), Linnaea borealis and Picea mariana. They also describe some jack pine stands in this region with minor Picea glauca canopy components.

(Forest/Woodland)

\section{Mixed Evergreen-deciduous}

\section{Broad-leaved}

\section{Mixed-evergreen-deciduous cold-deciduous forest/woodland}

\section{PICEA GLAUCA MIXED-EVERGREEN DECIDUOUS FOREST/WOODLAND ALLIANCE}

Picea glauca - Populus tremuloides - Populus balsamifera / (shrubs and herbs) White spruce - Trembling aspen - Balsam poplar

Preliminary Rank: S5

In the Central Parkland, this community is described from one site in Dry Island Buffalo Jump Provincial Park (Smith and Kondla 1972). A detailed description of community structure is not provided, but this type can be found on hillsides and along river valleys. Site conditions and understory composition are not described but the community is included in this report because of the spruce-dominated mixed-deciduous canopy. Total canopy coverage is roughly $12 \%$ aspen, $12 \%$ balsam poplar and $25 \%$ white spruce. This is a well drained, spruce-dominated community; two factors that differentiate it from others within this formation subgroup. This community represents a successional stage towards pure white spruce communities in the 

Parkland and Boreal Regions of Alberta. Forests with this cover type are not uncommon in Alberta, but clarification of understory species for this cover type in the Central Parkland is required.

Beckingham and Archibald (1996) describe three similar community types from the Boreal Region of Alberta (the dogwood Sw type e3.4, the dogwood $\mathrm{Pb}-\mathrm{Sw}$ type e2.3 and the horsetail $\mathrm{Pb}-\mathrm{Sw}$ type $\mathrm{f} 2.1$ ). These three communities have are spruce-dominated with aspen and balsam poplar canopy components at near equal proportions to the community described above. Understory associates of these boreal types include Rosa acicularis, Linnaea borealis, Viburnum edule and Aralia nudicaulis, but it is unclear whether these are included in the Parkland type. Similar spruce-dominated communities, as described by Beckingham et al. (1996), can be found in the Foothills Region of Alberta (the low-bush cranberry Sw type e4.2 and the horsetail Pb Sw type i2.1) but tend to have a Betula papyrifera or an Abies spp. canopy component at trace amounts.

\section{POPULUS TREMULOIDES MIXED-EVERGREEN DECIDUOUS FOREST/WOODLAND ALLIANCE}

Populus tremuloides - Populus balsamifera - Picea glauca / Rubus idaeus

Trembling Aspen - Balsam Poplar - White spruce / Wild red raspberry

Preliminary Rank: S5

In the Central Parkland, this community is described from five sites in the Blackfoot Provincial Recreation Area by Timoney and Robinson (1987). Canopy height of this type ranges from 21-28 $\mathrm{m}$ in height and tend to have high structural and species diversity, but an assessment of species variability between sites is not provided. This mature and old-growth forest occurs on well to imperfectly drained sites with Orthic Gray Luvisols, or Humic and Luvic Gleysolic soils where conditions are mesic-sub-hygric to hygric. Cornus stolonifera is a common understory associate. This community is differentiated from the Picea glauca - Populus tremuloides - Populus balsamifera / (shrubs and herbs) described above by its lower spruce canopy component and significantly moister site conditions. A formal assessment of abundance for this community is not available, but we have observed this community in the Boreal and Foothills Regions of Alberta and do not consider it rare.

This association is similar to the "aspen-balsam poplar / rose-raspberry / pink wintergreen", and "aspen / red-osier dogwood" associations of northern Alberta described by Beckingham (1993). Beckingham and Archibald (1996) describe a similar community type (the dogwood Pb-Aw types el.1, e1.2 and e1.3) from the Boreal Region of Alberta. Shrub associates of this boreal community can include Rosa acicularis, Cornus stolonifera and Viburnum edule. 

Populus tremuloides (Picea glauca) / Aralia nudicaulis / Cornus canadensis Trembling aspen (White spruce) / Wild sarsaparilla / Bunchberry

Preliminary Rank: S5

In the Central Parkland, this community is described from two sites, both from the Blackfoot Recreation Area (Timoney and Robinson 1998, Griffiths et al. 1997). Canopy cover can vary from aspen-dominated to a mix of aspen and white spruce, and some stands can have a significant cover of Populus balsamifera and Betula spp. This community occurs on mesic, well drained, north-facing slopes, and soils are commonly Orthic Gray Luvisols. Common understory associates can include Rubus pubescens, Rubus idaeus, Corylus cornuta, Viburnum edule, Amelanchier alnifolia, Cornus stolonifera and Symphoricarpos albus. The lack of Populus balsamifera as a canopy dominant differentiates this community from the Picea glauca-Populus tremuloides - Populus balsamifera in this formation. An assessment of variability between occurrences for this community is not available from the literature.

Timoney and Robinson (1998) describe this type as a Populus tremuloides (Picea glauca) / Aralia nudicaulis / Cornus canadensis community from south of Elk Island National Park, and Griffiths et al. (1997) describe it as a Picea glauca - Populus tremuloides / low shrub community from the same area. Both communities have identical site conditions and no variation in associated species, and as such are considered the same community type in this report.

Beckingham and Archibald (1996) describe a similar community type (the low-bush cranberry type d1.2) from the Boreal Region of Alberta, the only difference being a Rosa acicularis understory component $(<20 \%)$.

\section{Herbaceous}

Annual

\section{Narrow-leaved}

\section{Riparian herbaceous vegetation}

\section{SENECIO CONGESTUS HERBACEOUS ALLIANCE}

Senecio congestus

Marsh ragwort

Preliminary Rank: S5

In the Central Parkland, this community is described from one site on the foreshore of Beaverhill Lake by Griffiths et al. (1996). It is described as the Marsh Ragwort (Riparian) Zone by and can be found occupying land exposed by receding water levels. They describe three subzones of this community; an 

inner zone where the ragworts have died after flowering, a zone where the ragwort is in flower, and a zone where the ragwort is colonizing mud exposed during the current season. Soil conditions are not discussed. Associated plant species include Rumex maritimus, Aster brachyactis, Ranunculus cymbalaria, Chenopodium salinum and Hordeum jubatum. This community can disappear when water levels rise and the area it occupies is flooded. The species Senecio congestus is common in the northern Central Parkland Subregion and Boreal Region of Alberta (Moss 1983) and occurrence as a community of this species are not considered rare, although no formal assessments of community abundance are available. Because this type is only described from one site, an assessment of species variability between occurrences is not available. Natureserve (2001) describes a Senecio congestus Temporarily Flooded Herbaceous Alliance, but there are currently no details on any associations within that alliance.

(Herbaceous)

Herb

\section{Thread-like leaved}

\section{Intermittently flooded brackish herbaceous vegetation}

\section{RUPPIA MARITIMA INTERMITTENTLY FLOODED HERBACEOUS ALLIANCE}

\section{Ruppia maritima}

Widgeon grass

Preliminary Rank: S2

This community is described as a saline open water community occurring generally within the Grassland and Parkland Regions of Alberta by Wallis (1990). It occurs on unvegetated shores, where rooted vegetation is absent, and soil salinity is between 3 and 50 parts per million. It is restricted to saline, seasonally or permanently flooded marshes, channels, ponds, rivers or coastal wetlands or within inland, low-lying basins of high evaporation and low, fresh water inputs. Because this community has very specific water and soil chemistry requirements, its habitat is sensitive to anthropogenic influences. This plant association has been characterized as one of three major foods for waterfowl in the Missouri Coteau (Heidel et al. 2000, Metcalf 1931). An assessment of variability between occurrences for this community is not available from the literature.

Wallis (1990) mentions this community for Alberta in the Grassland-Parkland Region of eastern Alberta where it is apparently very localized (i.e. restricted to few water bodies). It may be very extensive in lakes where it occurs and might be more common in Alberta than previous surveys indicate, however, droughts may have severely impacted its habitat (C. Wallis, pers comm.). 

This community type occurs in the glaciated plains region of Alberta, Saskatchewan, Montana and North Dakota where it is typically in "closedbasin" watersheds, and often part of glacial outwash channels (Heidel et al. 2000). It is briefly described from California and the Lahontan Basin in Nevada (Natureserve 2001) but details on community persistence or variability are not available. Little is known of its current or past distribution other than along the California coast, where it has been much reduced in area by drainage and cultivation.

(Herbaceous)

(Herb)

\section{Toothed, broad leaves}

\section{Brackish herbaceous vegetation}

\section{POTENTILLA ANSERINA HERBACEOUS ALLIANCE}

\section{Potentilla anserina - Distichlis stricta}

Silverweed - Salt grass

Preliminary Rank: SU

In the Central Parkland, Fehr (1984) describes this community from one area near Wainwright, Alberta. He recorded Potentilla anserina at 30\% cover and Distichlis stricta at $15 \%$ cover. Associated species were all at covers of $5 \%$ or less. Salt-tolerant species found as associates in this community include Glaux maritima, Hordeum jubatum, Puccinellia nuttalliana, Salicornia rubra and Suaeda calceoliformis. This type is found in depressions where groundwater discharge makes the soil saline. Other site characteristics are not discussed. Records of this community type were not found elsewhere in the literature so a formal assessment of community variability between occurrences and provincial abundance is not available.

(Herbaceous)

Sedges and Rushes

Spiked Sedges

\section{Marl fen herbaceous vegetation}

\section{ELEOCHARIS QUINQUEFOLIA HERBACEOUS ALLIANCE}

Eleocharis quinquefolia

Few-flowered spike rush

Preliminary Rank: S3

In the Central Parkland, this community is described from one site in the Bilby Natural Area near Onoway by Griffiths and Griffiths (1987b). It is 

described as a Marl Fen or a bog forest associated with seepage of mineralrich groundwater. Soil and site conditions of this community are not discussed, and a detailed description of the community strata and an assessment of the variability between occurrences of this type in the Central Parkland are not available. Marl fens are considered by naturalists to be important for plant conservation because they tend to contain uncommon, showy plants, such as Tofieldia glutinosa, Parnassia palustris, Senecio pauperculus, Pedicularis groenlandica and Orchis rotundifolia.

Documentation on the frequency of this species forming communities in Alberta is not available. The species Eleocharis quinquefolia is considered to be potentially rare and restricted in range, and is ranked $\mathrm{S} 3$ for the province (L. Allen, pers comm.). As a community in the Central Parkland, occurrences are probably not common and, consistent with the species rank, the community type is ranked $\mathrm{S} 3$ as well.

In central and northwestern North Dakota, Eleocharis quinquefolia communities are found on slopes bordering wetlands and along river valleys (Heidel et al. 2000). This plant association is documented from North and South Dakota, and northeastern Montana (Heidel et al. 2000) and is similar in site conditions and associated species to the Central Parkland occurrence described above. An upper-subalpine and lower alpine Eleocharis quinquefolia wetland community is described from Colorado (Natureserve 2001). Stands are dominated by Eleocharis quinquefolia and are easily recognized by their homogeneity (usually little more than Eleocharis quinquefolia and Carex aquatilis), and the sparse nature of the vegetation growth (these types are ranked G4 by The Nature Conservancy). Because of elevation and hydrological differences (i.e. seasonally flooded), this alpine community could not be considered the same as the Central Parkland type discussed above.

\section{Temperate or subpolar sedge grassland}

\section{CAREX SPP. SEDGE GRASSLAND ALLIANCE}

Carex group - Calamovilfa longifolia

Carex group - Sand grass

Preliminary Rank: S5

In the Central Parkland, this community is described from 15 sites near the Wainwright - Metiskow area of Alberta by H. Loonen (unpublished data). The Carex group accounts for approximately $30 \%$ cover (range $12-50 \%$ ) with Calamovilfa longifolia at approximately $15 \%$ cover (range 7-30\%). The Carex group consists of Carex obtusata, C. filifolia, C. pensylvanica and C. stenophylla of roughly equal cover. This type is a component in a mosaic with (unspecified) shrub and tree communities. This community occurs on 

submesic, rapidly drained areas of various aspects on hummocky, undulating terrain. Soils are Orthic Dark Brown Chernozems. Associated species (both less than $8 \%$ cover) include Stipa curtiseta and Koeleria macrantha. This community frequently makes up $20-70 \%$ of the landscape. It is considered common in the Central Parkland Subregion and the Grassland Region of Alberta (H. Loonen pers comm.) but is not documented elsewhere in the literature.

Carex group - Koeleria macrantha

Carex group - June grass

Preliminary Rank: S5

In the Central Parkland, this community is described from 40 sites near Wainwright, Alberta by $\mathrm{H}$. Loonen (unpublished data). It is differentiated from the previous community by the dominance of Koeleria macrantha. The Carex group accounts for approximately $30 \%$ cover (range 9-72\%) with K. macrantha accounting for approximately $8 \%$ (range 1-20\%). The Carex group consists of Carex obtusata, C. filifolia, C. pensylvanica and C. stenophylla of roughly equal cover. This type occurs on submesic, rapidly drained sites with Orthic Dark Brown Chernozem soils and hummocky, undulating terrain. Nutrient conditions for this community are described as submesotrophic and it occurs on various aspects. Associated species (less than $5 \%$ cover) include Bouteloua gracilis, Calamovilfa longifolia, Stipa curtiseta, Cerastium arvense and Juniperus horizontalis. In these areas the grassland community makes up approximately $20-70 \%$ of the landscape. This community relies on the presence of grazing to exist. It is considered common throughout Central Parkland Natural Subregion and the Grassland Region of Alberta (H. Loonen pers comm.) but is not documented elsewhere in the literature.

Carex group - Stipa curtiseta

Carex group - Barkworth

Preliminary Rank: S5

In the Central Parkland, this grassland community type is described from 27 sites near the Ribstone and Czar areas of Alberta by H. Loonen (unpublished data). This community is differentiated from the previous two communities by the dominance of Stipa curtiseta. The Carex group accounts for approximately $25-50 \%$ cover in ungrazed areas, with Stipa curtiseta accounting for approximately 5-25\% cover. The Carex group consists of Carex obtusata, C. filifolia, C. pensylvanica, and C. stenophylla of roughly equal cover. Associated species (less than 16\%) include Festuca hallii and Calamovilfa longifolia. This type can be found on rapidly drained, mesic, gentle slopes with various aspects and submesotrophic conditions. Soils are Ortho Dark Brown Chernozems. Where this community is found the grassland component can cover $20-70 \%$ of the landscape. This community is considered common throughout Central Parkland Natural Subregion and the 

Grassland Region of Alberta (H. Loonen pers comm.) but it is not documented elsewhere in the literature.

Temperate or subpolar intermittently flooded sedges and rushes

\section{CAREX ATHERODES INTERMITTENTLY FLOODED HERBACEOUS ALLIANCE}

Carex atherodes - Carex rostrata

Awned sedge - Beaked sedge

Preliminary Rank: S2

In the Central Parkland, this community is described from one location near Lister Lake, Alberta by Griffiths et al. (1996). Carex atherodes and Carex rostrata show varying degrees of dominance (not specified) amongst a diversity of associated species at unspecified coverages. Associated species include Drepanocladus aduncus, Calamagrostis stricta, Sium suave, Epilobium palustre, Galium trifidum and Rumex occidentalis. This community can be found in areas where the water table is near ground level. Soil and site conditions are not discussed. This type is characteristic of eutrophic sites subject to flooding. Carex rostrata is considered a rare species in Alberta and is ranked S2 for the province (ANHIC 2001); the rank of this community type reflects this. This community type is not documented elsewhere in the literature. Natureserve (2001) notes Carex atherodes occurring with several associated species including Polygonum amphibium, Calamagrostis canadensis, Carex lasiocarpa, Spartina pectinata, and Carex aquatilis but describe no such community comparable to this Central Parkland type.

\section{Temperate or subpolar permanently-flooded sedges and rushes}

\section{CAREX SPP. PERMANENTLY FLOODED HERBACEOUS ALLIANCE}

Carex atherodes - Scolochloa festucacea - Eleocharis palustris - Typha latifolia Awned sedge - Spangeltop - Common spike rush - Common cattail Preliminary Rank: S5

In the Central Parkland, this community is described from one site near Rumsey, Alberta by (Fehr 1982). It occupies the subhydric and hydric margins of relatively deep freshwater sloughs. Drainage is very poor with areas of open water being common. Cover of the herb-dwarf shrub layer is roughly $90 \%$. Other characteristic species can include Alopecurus aequalis, Rumex maritimus, Glyceria grandis, and Beckmannia syzigachne. This community is differentiated from the Carex atherodes Intermittently flooded Herbaceous Alliance by hydrological regime (i.e. this community is permanently flooded). The perimeters of many sloughs in the Central 

Parkland are vegetated with this community type (Fehr 1982). An assessment of variability between occurrences for this community is not available from the literature.

Natureserve (2001) notes a Scolochloa festucacea Herbaceous Vegetation association where Scolochloa festucacea occurs with low covers of Carex atherodes. This marsh type is found in the northeastern Great Plains and northern tallgrass prairie region of the United States and Canada but cannot be considered similar as it lacks Eleocharis palustris and Typha latifolia components and is seasonally, not permanently, flooded.

Carex pseudo-cyperus - Calla palustris

Cyprus sedge - Water arum

Preliminary Rank: S1S2

In the Central Parkland, Moss (1928) only found this association in two areas; forming a narrow fringe around a water body backed by muskeg of young bog forest, and as wetland adjoining two lakes. According to Allen (2001), this community can form islets in ponds where the water is shallow enough, and it is often associated with Carex diandra. Specific site and soil conditions are not documented, nor are assessments of variability between occurrences. Well-developed occurrences of this community are known only from three sites near Elk Island National Park (G. Griffiths pers comm.), therefore, the community has been assigned a rank of S1S2. This community type is not well described in the literature and is on the Alberta Plant Community Tracking List (Allen 2001).

\section{Temperate or subpolar seasonally flooded sedges and rushes}

\section{CAREX ATHERODES SEASONALLY-FLOODED HERBACEOUS ALLIANCE}

Carex atherodes - Calamagrostis inexpansa

Awned sedge - Northern reed grass

Preliminary Rank: S4

In the Central Parkland, this community is described by Wroe (1971) from one area near Dry Island Buffalo Jump Provincial Park. He noted that the Carex spp. cover is roughly $90 \%$ and Calamagrostis inexpansa cover is approximately $61 \%$. Beckmannia syzigachne cover is approximately $10 \%$. Coverage of plants reflect the depth of water and the length of flooding, in deeper water Glyceria grandis, Typha latifolia, and Sium suave can be found. This community type is associated with rolling topography; it occurs in depressions that hold water during part of the growing season. Site and soil conditions are not discussed and an assessment of species variability between occurrences is not available. Associated species include Carex rostrata and Carex athrostachya. This community is differentiated from other Carex 

atherodes Herbaceous Alliances by hydrological regime (i.e. it is not permanently flooded). This is considered a common community type, but it is restricted in the area that it can occupy (A.H. Weerstra pers comm.) and is hence ranked S4. It is not well documented in the literature.

Carex atherodes - Scolochloa festucacea - Poa palustris - Cirsium arvense Awned sedge - Spangeltop - Fowl bluegrass - Canada thistle Preliminary Rank: SU

In the Central Parkland, this community is described from one area near Wainwright, Alberta by Fehr (1982). Coverages of the dominant species were estimated as follows: Carex atherodes coverage is $35 \%$, Scolochloa festucacea is $30 \%$, Poa palustris is $20 \%$ and Cirsium arvense is $19 \%$. Fehr (1982) estimated the herb-dwarf shrub layer at between 85 and $95 \%$ cover. Associated species include Potentilla anserina, Mentha arvensis, and Hordeum jubatum all at coverages of less than $8 \%$. This community type is found in hygric and subhydric depressions. It occurs in very poorly to imperfectly drained areas with Rego Humic Gleysolic soils, typically in sloughs that dry up in summer. This community type is prevalent in the kettle bottoms and valleys of the Central Parkland where there is little open standing water. The provincial abundance of this community type is not clear and it is not well documented in the literature. An assessment of variability between occurrences for this community is not available from the literature.

Natureserve (2001) notes a Scolochloa festucacea Herbaceous Vegetation association where Scolochloa festucacea occurs with low covers of Carex atherodes. This marsh type is found in the northeastern Great Plains and northern tallgrass prairie region of the United States and Canada and is seasonally flooded. It lacks the Poa palustris and Cirsium arvense components of the Central Parkland community, but these are introduced species; pre-introduction of these non-natives, this Parkland community might have been very similar to the community described by Natureserve (2001).

\title{
ELEOCHARIS PALUSTRIS SEASONALLY FLOODED HERBACEOUS ALLIANCE
}

\author{
Eleocharis palustris \\ Common spike rush \\ Preliminary Rank: S5
}

Wallis (1990) describes this community as occurring in moderately saline emergent marshes of the Central Parkland Natural Subregion of Alberta. The structure of this community is not provided in the literature. Associated species for Alberta types are not documented, nor is an assessment of species variability between occurrences. The common spike-rush plant community occurs in slightly to moderately brackish wetlands, including prairie potholes 

and riparian settings that are seasonally flooded (Heidel et al. 2000). The species Eleocharis palustris is widely distributed throughout Alberta (Moss 1983) but its occurrence as a community type in the province is not well documented.

This community type is well documented from the central and northern Great Plains, possibly extending into the Southwest and the Pacific Northwest states, and is a major type at low elevations throughout Montana (Heidel 2000, Hansen et al. 1995). This plant association is characterized by short-statured, fine-textured vegetation in localized areas where mineral-rich ground water flow emerges at the ground's surface. Associated species for Montana communities include Eleocharis acicularis, Rumex crispus and Hordeum jubatum, but an assessment of community variability between occurrences in not available.

\section{Temperate or subpolar temporarily flooded sedges and rushes}

\section{CAREX ATHERODES TEMPORARILY FLOODED HERBACEOUS ALLIANCE}

\section{Carex atherodes / Lemna minor}

Awned sedge - Common duckweed

Preliminary Rank: S5

In the Central Parkland, this community type is described by Griffiths and Griffiths (1987b) from one site near Onoway, Alberta. This type is described as "beds of awned sedge occurring in morainal depressions, either in moist soil as monocultures of Carex atherodes or in shallow water in association with Lemna minor" (Griffiths and Griffiths 1987b). Site conditions, soil type and associated species are not discussed. This community is considered common on intermittently flooded ground in Alberta (G. Griffiths, pers comm.) but is not well documented in the literature. An assessment of structural variability between occurrences is not available.

A similar community type is described by Schneider et al. (1997). This awned sedge wet meadow occurs in the northern tallgrass prairie region of the United States and Canada. Stands occur on lowland sites, typically in depressions, basins or along streams and rivers, having fresh or moderately saline standing water for several weeks each year. Associated species and site conditions are not discussed for this prairie type.

\section{Temperate or subpolar semipermenantly flooded sedges and rushes}

\section{CAREX AQUATILIS SEMIPERMENANTLY FLOODED HERBACEOUS ALLIANCE}

Carex aquatilis - Carex utriculata

Water sedge - Greater beaked sedge 

Preliminary Rank: S4

In the Central Parkland, this community is described by Griffiths et al. (1997) from one site in the Blackfoot Recreation Area in Alberta. This association is recognized by the presence of both Carex aquatilis and Carex utriculata in roughly equal proportions, but associated species and soil conditions are not discussed. This community type is a common fen that occurs in wet, morainal depressions and along the shores of lakes and ponds representing the interface between water sedge fen and aquatic, open water vegetation. This is considered a common fen type throughout Alberta (Griffiths et al. 1997) but is not well documented provincially in the literature. An assessment of structural variability between occurrences is not available.

This community has similar dominants and moisture regimes (i.e. poorly drained, moist areas) to the Carex aquatilis type mentioned from the USA Great Plains by Schneider et al. (1997) and to the Carex rostrata-Carex aquatilis type described from the Manito Sandhills in Saskatchewan by Thorpe and Goodwin (1993). Associated species and coverages are not provided for comparison for the community mentioned by Schneider et al. (1997). However, associated species in Saskatchewan types include Typha latifolia, Calamagrostis inexpansa and Mentha arvensis at unspecified coverages. In Colorado, the Carex aquatilis - Carex utriculata community type is considered common and generally occurs in small to moderate-sized patches in very shallow, slow-moving to still water, or on saturated soils near low-order streams, lakes, and backwater areas of larger rivers (Bourgeron and Engelking 1994). This type is ranked G4 by The Nature Conservancy (Natureserve 2001).

\section{SCIRPUS PALUDOSIS PERMANENTLY FLOODED HERBACEOUS ALLIANCE}

Scirpus paludosus

Prairie bulrush

Preliminary Rank: S4

In the Central Parkland, this community is described by Fehr (1982) from one area near Wainwright, Alberta and from the Parkland and Grassland Regions of Alberta in saline marshes by Wallis (1990). It occurs as a wide band around saline sloughs. It is described by Wallis (1990) as a saline, emergent marsh dominated by prairie bulrush with water contributing roughly $20 \%$ cover (range 5-35\%). Associated species and soil types are not discussed. This community is considered common in the parkland region (C. Wallis pers comm.) as is the species Scirpus paludosus, but a formal assessment of its occurrence as a community is not available. Saline marshes are not uncommon in the Parkland or Grassland Regions, but would be the limiting factor for area extent of this community type. Natureserve (2001) describes the species Scirpus paludosus as SR for Alberta $(\mathrm{SR}=$ reported from) but lists 

no communities dominated by this species. This community was not found elsewhere in the literature.

\section{SCIRPUS SPP. SEMIPERMENANTLY FLOODED HERBACEOUS ALLIANCE}

Scirpus acutus

Great bulrush

Preliminary Rank: S5

In the Central Parkland, this community is described from two sites in Dillberry Provincial Park (Meijer and Karpuk 1999), one site in the Blackfoot Provincial Recreation Area (Griffiths et al. 1997), and generally from emergent and saline marshes in the Grassland and Parkland Regions of Alberta (Wallis 1990). This community occurs along lakeshores in poorly drained areas with Typic and Terric Humisolic soils. Moisture conditions tend to be subhydric with a hypereutrophic or eutrophic nutrient regime (Meijer and Karpuk 1999). Associated species include Cirsium arvense, Rumex occidentalis and Solidago canadensis.

Griffiths et al. (1997) describe a Scirpus acutus - Scirpus validus community occurring in narrow bands along the shores of lakes or ponds in the Blackfoot Recreation Area. Wallis (1990) describes this same community as occurring in moderately saline emergent marshes in the Parkland and Grassland regions of Alberta. Published descriptions of this community do not allow for structural comparisons or comparisons of species coverages between occurrences.

Elsewhere, this bulrush community is noted as among the most common plant associations of semi permanently flooded wetlands in parts of northeastern Montana (Thompson 1994) and at low elevations throughout Montana (Hansen et al. 1995, Heidel et al. 2000). Scirpus acutus is considered common in Alberta and the USA both as a plant species and a dominant community type (Moss 1983, Heidel et al. 2000, Hansen et al. 1995, Thompson 1994), but documented occurrences are not of sufficient detail to afford comparisons of coverage values and structural diversity.

Scirpus paludosus - Puccinellia nuttalliana - Hordeum jubatum - Distichlis stricta Prairie bulrush - Nuttall's salt meadow grass - Foxtail barley - Salt grass Preliminary Rank: SU

In the Central Parkland, this community type is described by Fehr (1982) from three sites near Rumsey, Alberta. This community type occupies subhydric saline depressions where water contributes on average $20 \%$ cover (Fehr 1982). It occurs in wide bands around saline sloughs where each of the dominant species occupy a particular location along a moisture gradient. From wettest to driest in this transitional zone the order of species occupancy 

is Scirpus paludosus, Puccinellia nuttalliana, Hordeum jubatum, and Distichlis stricta. Associated species and soil types are not discussed. Dodd and Coupland (1966) note that because each species in this community can dominate a transitional zone of moisture and salinity, each species could also be considered as its own community type. All dominant species are widespread in Alberta (Moss 1983) but the occurrence of this community type is not well documented provincially or elsewhere. As such, an assessment of structural variability between occurrences is not available.

Scirpus acutus - Liverworts

Great bulrush - Liverworts

Preliminary Rank: SU

In the Central Parkland, this community is described by Meijer and Karpuk (1999) from one site in Dillberry Lake Provincial Park. It occurs in a poorly drained lacustrine deposit with Rego Gleysolic soils, a subhydric moisture regime and hypereutrophic nutrient conditions. The species composition of the liverwort group was not defined. Associated species include Solidago canadensis, Rumex occidentalis, Cirsium arvense and Scirpus pungens. This community could be similar to the Scirpus acutus community described above, but further work is required to determine associated species of that community before appropriate comparisons can be made with this type. This community is not well documented in the literature so the abundance of this type is not clear and an assessment of structural variability between occurrences is not available.

\section{Scirpus pungens}

Three-square rush

Preliminary Rank: S4

This community is noted by Wallis (1990) as occurring generally in emergent and saline marshes of the Parkland and Grassland Regions of Alberta. It is described as a saline emergent marsh dominated by three-square rush (Wallis 1990). It occurs in depressional areas and around the perimeters of saline marshes in Alberta. Soil and nutrient conditions are not discussed. Little information is available for this community, but it is possible that it is similar to, or part of, the Scirpus pungens - Hordeum jubatum - Puccinellia nuttalliana community described below. Associated species and specific site conditions are not clear from the literature. The species Scirpus pungens is well documented across Alberta and Canada (Moss 1983, C. Wallis, pers comm.) but more work is required to assess the frequency of its occurrence as a community. As such, an assessment of structural variability between occurrences is not available.

Scirpus pungens - Hordeum jubatum - Puccinellia nuttalliana

Three square rush - Foxtail barley - Nuttall's salt meadow grass 

Preliminary Rank: SU

In the Central Parkland, this community is described by Meijer and Karpuk (1999) from three sites in Dillberry Lake Provincial Park. It is described as a shallow marsh with the three dominant species occurring at unspecified coverages. It occurs in poorly drained, saline, shallow marshes. This type is characterized by very rich (hypereutrophic) nutrient conditions, and Rego Gleysolic or Gleyed Rego gleysolic soils. Associated species include Ranunculus cymbalaria, Suaeda calceoliformis and Puccinellia nuttalliana. The three component species of this community are common in Alberta (Moss 1983) but the occurrence of these species together as a community type is not well documented. This community is not described elsewhere in the literature and, therefore, an assessment of structural variability between occurrences is not possible.

\section{Temperate or subpolar sedges or rushes on sandy substrate}

\section{CAREX SPP. RAPIDLY DRAINED HERBACEOUS ALLIANCE}

Carex siccata - Calamovilfa longifolia

Hay sedge - Sand grass

Preliminary Rank: S3

In the Central Parkland, this community is described from one site by Fehr (1984) near the Wainwright area of Alberta. This community occurs in active blowouts on south or south-west-facing slopes on undulating areas where there is little relief. Soils are Orthic Regosolols. It occurs on xeric to very xeric sites with rapid drainage. These sites are characterized as sandy, possessing little substrate. Associated species are not discussed. This community is an important colonizer of bare sand areas in the Central Parkland of Alberta. Because this community type is restricted to active blowouts, it has a limited range (Fehr 1984). This community type is not well documented in Alberta and an assessment of structural or species variability between occurrences is not possible.

Natureserve (2001) describes a Carex siccata Herbaceous Alliance, however, this alliance occurs in dry to moderately moist, open or thinly wooded, grassy slopes in the Rocky Mountains. Elevations range from $2400 \mathrm{~m}$ in Arizona to $3900 \mathrm{~m}$ in Colorado. These types are typically found near treeline on southoriented, stabilized, fine-talus slopes, and are as such not comparable to Central Parkland types that differ in substrate, local disturbance (i.e. active blowouts, blowing sand, etc.) and elevation.

(Herbaceous)

(Sedges and Rushes) 



\title{
Aquatic Rushes
}

Temperate or subpolar semipermanently flooded aquatic rushes

\section{TYPHA LATIFOLIA SEMIPERMANENTLY FLOODED HERBACEOUS ALLIANCE}

\section{Typha latifolia}

Common cattail

Preliminary Rank: S5

In the Central Parkland, this community type is described from two sites in Dillberry Lake Provincial Park by Meijer and Karpuk (1999), from one site near Lister Lake by Griffiths et al. (1996) and from one site in the Blackfoot Provincial Recreation Area by Griffiths et al. (1997). This community is dominated by Typha latifolia and can have significant coverages of floating duckweed (Lemna trisulca) indicative of areas containing standing, eutrophic water (Griffiths et al. 1995). This marsh community is found in level and depressional areas along the shorelines of water bodies, and is extensive in ditches and in riparian zones. It is found in areas where the water level is above the rooting zone for at least part of the growing season, slope and aspect are level, and nutrient levels are high. In the Central Parkland, this community occurs in very poorly drained areas with Rego Gleysol or Rego Humic Gleysolic soils. Formal assessments of structure and variability between occurrences are not available for this community.

We have observed this community around ponds, lakes, sloughs and flooded areas throughout the province. Beckingham and Archibald (1996) describe this community type from the Boreal Region of Alberta (cattail marsh type h1.1), and Beckingham et al. (1996) describe it from the Foothills Region of Alberta (cattail marsh type n1.1). It is also mentioned from throughout the Northern Great Plains of Canada and the USA by Heidel et al. (2000) in semipermanent wetlands, ponds and drainages where, under more alkaline conditions, Typha angustifolia can begin to dominate.

(Herbaceous)

\section{Graminiod}

\author{
Linear, parallel-veined leaves
}

\section{Temperate or subpolar grasslands}

AGROPYRON TRACHYCAULUM HERBACEOUS ALLIANCE

Agropyron trachycaulum - Hordeum jubatum - Elymus canadense

Slender wheat grass - Foxtail barley - Canada wild rye

Preliminary Rank: SU 

In the Central Parkland, this community is described by Bradley and Bradley (1977) from one site on the Neutral Hills near Provost, Alberta. It occurs on south-facing grassland slopes ( $10 \%$ grade) with little or no shrub cover. We have observed this community occurring on upper-slope positions between thickets of silverberry growing in lower-slope positions, and young, stunted aspen growing on the tops and north face of the Neutral Hills. This community is generally low-growing due to browsing pressure of deer and elk in the area, and patches of exposed soil accounting for $<5 \%$ cover are also characteristic of this community. Associated species are not discussed but Artemisia longifolia can be a common. This community is made up of species that are widespread in the Central Parkland (Moss 1983), however, a formal assessment of abundance or structural variability between occurrences is not available for this community. The Agropyron communities of Alberta are discussed in detail by Vujnovic and Bentz (2001), but this community type is not mentioned therein.

\title{
AGROSTIS SCABRA HERBACEOUS ALLIANCE
}

Agrostis scabra - Achillea millefolium - Antennaria parvifolia

Hair grass - Common yarrow - Small-leaved everlasting

Preliminary Rank: SU

In the Central Parkland, this community is described by Fehr (1982) from two sites near Rumsey, Alberta. Agrostis scabra is the dominant species with an average cover of $23 \%$. The two subdominant species Achillea millefolium and Antennaria parvifolia both have covers of $15 \%$. This community occurs in shallow, subxeric to submesic depressions on moraine plateau hilltops. Soils are moderately-well to imperfectly drained Dark Brown Chernozems with variable moisture regimes. The moisture regime between stands can vary considerably (but not specified exactly how). Common associates are Bouteloua gracilis ( $2.5 \%$ cover), Koeleria cristata $(2.5 \%$ cover) and Galium boreale $(2.5 \%$ cover). All dominant species that compose this community are widespread, but the occurrence of these species together as a community type is not well documented. The overall abundance of this community is unknown and a range of cover values between occurrences (albeit $n=2$ ) is not available.

\section{BOUTELOUA GRACILIS HERBACEOUS ALLIANCE}

\author{
Bouteloua gracilis - Artemisia frigida \\ Blue grama - Pasture sagewort \\ Preliminary Rank: S4S5
}

In the Central Parkland, this community is described by Fehr (1982) from six sites near Rumsey, Alberta. It is described as occupying xeric and subxeric sites on the upper and middle sections of well drained, south-facing slopes of 

20-35 degrees. Soils are Dark Brown Chernozems. Coverage of the dominant species, Bouteloua gracilis, is $35 \%$ and Artemisia frigida has a coverage of $17 \%$. Associated species at coverages $<12 \%$ include Koeleria cristata, Stipa curtiseta, Antennaria nitida, Heterotheca villosa, Comandra pallida, Haplopappus spinulosus, Lygodesmia juncea and Thermopsis rhombifolia. Although Bouteloua gracilis is a common grass species, BoutelouaArtemisia communities are not represented elsewhere in the literature. A.H. Weerstra (pers comm.) sampled several Bouteloua community types throughout the Central Parkland of Alberta and considers this a common community type in this subregion. This community is composed of provincially common species (Moss 1983) but their occurrence together as a community type has not been formally assessed, and a comparison of structural variability between occurrences is not possible.

\section{CALAMAGROSTIS SPP. HERBACEOUS ALLIANCE}

\section{Calamagrostis canadensis}

Marsh reed grass

Preliminary Rank: S5

In the Central Parkland, this community type is documented from the Blackfoot Recreation Area (Timoney and Robinson 1997) and from near Onoway, Alberta (Griffiths and Griffiths 1987b). This community is typically a patchy mosaic of Calamagrostis canadensis. It occurs on imperfectly to poorly drained sites bordering water bodies or in seasonally-inundated depressions. Plants commonly associated with marsh reed grass include Poa pratensis, Epilobium angustifolium, Carex spp., Salix spp., Pinus banksiana, Picea engelmannii, and Populus tremuloides. Although only formally documented in a few locations from the Central Parkland, we have observed this community type province-wide in similar site conditions. Information is not available for a comparison of structural variability between occurrences.

Calamagrostis canadensis can be found in moist woods, meadows, wetlands, clearings and lakeshores throughout Alberta (Johnson et al. 1995) where it often forms dominant communities. Marsh reed grass grows in pine, spruce, and mixed wood forests north of $35^{\circ}$ latitude from Newfoundland to Alaska (Lieffers and Macdonald 1993), and is the most common and widespread Calamagrostis species in North America (USDA 1988). In the United States, marsh reed grass is documented as a water loving plant commonly growing on imperfectly to moderately well-drained sites; soils are often peat-based, and have a pH as low as 3.5 (USDA 1988). Schneider et al. (1997) describe this community type as occurring in the grasslands of Montana.

Calamagrostis stricta - Juncus balticus - Potentilla anserina - Aster hesperius Narrow reed grass - Wire rush - Silverweed - Western willow aster Preliminary Rank: S4 

In the Central Parkland, this community is described by Griffiths et al. (1996) from one area near Lister Lake, Alberta. It is described as a moist, saline meadow and represents the transition between moist meadow and willow shrubbery. Species diversity averages $10-25$ species per $10 \times 10 \mathrm{~m}$ plot and can include Glaux maritima, Primula incana and Aster falcatus. Soils, site conditions and species coverages are not discussed. This community is considered common on shores in the Central Parkland but it is possible it has been converted to "improved" pasture in some areas, hence was given an S4 rank (G. Griffiths, pers comm.). This community is not documented elsewhere in the literature, so an assessment of structural variability between occurrences is not available.

\section{DISTICHLIS STRICTA HERBACEOUS ALLIANCE}

\section{Distichlis stricta}

Salt grass

Preliminary Rank: S4

In the Central Parkland, this community is documented from one site in the Rumsey area by Fehr (1982), and occurs generally as a hypersaline dry meadow in the Parkland and Grassland Regions of Alberta (Wallis 1990). This community occurs as a wide band of vegetation around saline sloughs, occupying areas which are less saline than areas occupied by Puccinellia nuttalliana, forming almost pure stands with a basal cover of $>20 \%$ (Wallis 1990). Glaux maritima can be found frequently in this community type. Distichlis stricta is ranked S4 in Alberta (ANHIC 2001). Its occurrence as a provincial community type is not well represented in the literature. As such, an assessment of structural variability between occurrences is not available.

Salt grass is distributed across western North America and is generally restricted to low-lying alkaline or saline areas. It is a dominant species on saline areas occurring on a variety of soil textures and moisture levels as far south as Oklahoma (Dodd and Coupland 1966) and can be found as far north as Wood Buffalo National Park (Schwartz and Wein 1997). In Colorado and Wyoming, salt grass covers an estimated 500,000 ha (Mueller et al. 1985). It occupies much less extensive areas in the warm desert region south of Utah, but it is prominent in the most saline parts of desert meadows (Dodd and Coupland 1966).

Natureserve (2001) describes this community in semi-arid and arid western North America, from southern Saskatchewan to Mexico. Stands are found in lowland habitats such as playas, swales and terraces along washes that are typically intermittently flooded. The flooding is usually the result of highly localized thunderstorms. This association may also occur in other flood regimes (temporarily, seasonally, and semipermanently). Soil texture ranges 

from clay loam to sandy clay. Vegetation cover is sparse to dense and is dominated by Distichlis stricta occurring in nearly pure stands. Minor cover of associated graminoids may include Muhlenbergia asperifolia, Hordeum jubatum, Agropyron smithii, Sporobolus airoides, Carex filifolia, Eleocharis palustris, Puccinellia nuttalliana, and Juncus balticus. Associated forbs, such as Iva axillaris, Helianthus spp., Aster spp. (from lower salinity sites), Salicornia rubra, Triglochin maritima, and Suaeda spp., may also be present. Shrubs are rare, but scattered Atriplex canescens and Sarcobatus vermiculatus may be present.

Distichlis stricta - Agropyron smithii

Salt Grass - Western wheat grass

Preliminary Rank: S4

This community type is noted by Wallis (1990) as a saline dry meadow type occurring generally within the Parkland and Grassland Regions of Alberta. This community is transitional between the highest, driest portion of the halophytic communities, and the semi-halophytic communities found further upslope. Soil types are not discussed. Common associates include Aster ericoides and Grindelia squarrosa. The inclusion of Agropyron smithii suggests drier site conditions and is thus differentiated from the Distichlis stricta community type. Distichlis stricta - Agropyron smithii is less abundant than the Distichlis stricta community type, but is still widespread in the Central Parkland Natural Subregion and Grassland Region of Alberta (C. Wallis, pers comm.). This community type is not well represented in the literature, and we found no instances where cover values were recorded allowing for a comparison of species variability between occurrences of this type.

\title{
ELYMUS CANADENSIS HERBACEOUS ALLIANCE
}

\author{
Elymus canadensis - Poa pratensis - Glycyrrhiza lepidota \\ Canada wild rye - Kentucky bluegrass - Wild licorice \\ Preliminary Rank: S4
}

In the Central Parkland, this community type is described by Griffiths et al. (1997) from one site in the Blackfoot Provincial Recreation Area. Coverages of the dominant species are not discussed, nor are soil types. This dry grassland community is found on south-facing, steep slopes (river valleys or steep hills) where shrubs are relatively sparse and, when present, consist mainly of Symphoricarpos occidentalis. Shrubs are overtopped by grasses and wild licorice. This community is not considered uncommon but it is found on steep south-facing slopes potentially limiting its overall distribution (G. Griffiths pers comm.). Because this community is only described from one site a comparison of species and structural variability between occurrences is not possible. 



\section{KOELERIA MACRANTHA HERBACEOUS ALLIANCE}

Koeleria macrantha - Agropyron smithii

June grass - Western wheat grass

Preliminary Rank: SU

In the Central Parkland, this community is described by Wroe (1971) from one area near Dry Island Buffalo Jump, and by Fehr (1982) from one area near Wainwright, Alberta. This grassland community type occupies xeric sites on level areas and lower slopes with Black and Brown Solonetz soils. Coverages of the dominant and associated species are not provided, and moisture and nutrient conditions are not discussed. Common associates include Selaginella densa, Carex stenophylla, Poa secunda, Grindelia squarrosa and Distichlis stricta. It is considered a minor community type in the Rumsey area (Fehr 1982) but is not well documented in the literature, so the provincial abundance and structural variability between occurrences are not clear.

A similar community type is noted from the northern and western Great Plains, Rocky Mountains, and the interior western United States (Natureserve 2001). This community type is described as a Agropyron smithii Herbaceous Vegetation with Koeleria macrantha achieving local dominance (at unspecified coverages). It can be found on level to gently sloping terrain, on alluvial fans, swales, river terraces, floodplains, valley floors and basins. The soils are clay, clay loam, and silt loam. Agropyron smithii can dominate the moderate to dense (40-100\% cover) herbaceous canopy that grows $0.5-1 \mathrm{~m}$ tall. Other graminoids that co-occur and may achieve local dominance are Eleocharis palustris, and Poa spp. Other associated species can include Artemisia ludoviciana, Eriogonum spp., Bouteloua gracilis, Nassella viridula, and Stipa comata. Shrubs and dwarf-shrubs are rare in this community. Natureserve (2001) refers the reader to Thilenius et al. (1995), Baker (1984a), and Baker and Kennedy (1985).

\section{STIPA SPP. HERBACEOUS ALLIANCE}

\section{Stipa comata - Koeleria macrantha - Agropyron smithii}

Needle and thread grass - June grass - Western wheat grass

Preliminary Rank: SU

In the Central Parkland, this community is described by Meijer and Karpuk (1999) from three sites in Dillberry Lake Provincial Park. A structural description of this community is not provided, but it can be found on stabilized dune areas with little sign of recent erosion and visible evidence of soil formation. It occurs on south to south-west facing slopes with Orthic Dark Brown soils, rapid drainage, a subxeric moisture regime, and 

submesotrophic nutrient conditions. Forbs and grasses that can be present include Solidago missouriensis, Thermopsis rhombifolia, Calamovilfa longifolia and Agropyron trachycaulum. The three dominant species are provincially common but their occurrence together as a community type is not clear. The provincial abundance of this type is unknown and it is not documented elsewhere in the literature.

Stipa comata - Koeleria macrantha - Agropyron trachycaulum - Agropyron smithii Carex obtusata

Needle and thread grass - June grass - Slender wheat grass - Western wheat grass Blunt sedge

Preliminary Rank: SU

In the Central Parkland, this community is described by Meijer and Karpuk (1999) from five sites in the north section of Dillberry Lake Provincial Park. It occurs on south slopes and flat, upland areas associated with hummocky, glaciofluvial landscape. It is found in xeric, rapidly drained areas with Orthic Dark Brown soils, and submesotrophic nutrient conditions. Coverages of dominants are not provided, but common associates include Artemisia frigida, Petalostemon purpureum and Calamovilfa longifolia. The presence of blunt sedge (Carex obtusata) sets this community apart from other communities found on eolian deposits throughout the grasslands (Meijer and Karpuk 1999), namely the Stipa comata - Koeleria macrantha - Agropyron smithii community described above. This community is not documented elsewhere in the literature and the provincial abundance of this community is not clear.

Stipa comata - Poa sandbergii - Carex obtusata

Needle and thread grass - Sandberg bluegrass - Blunt sedge

Preliminary Rank: SU

In the Central Parkland, this community is documented by Meijer and Karpuk (1999) from one site in Dillberry Lake Provincial Park. A description of dominant species coverages is not provided. This community is found in morainal depressions with imperfect drainage, subhygric moisture conditions and a mesotrophic nutrient regime. Soils are Gleyed Solonetzic Black Chernozems with a clay or clay-loam texture. Common associates include Achillea millefolium, Antennaria parviflora, Astragalus spp. and Anemone cylindrica. The presence of Grindelia squarrosa in this community indicates saline conditions. This community was not found elsewhere in the literature and the provincial abundance is not clear.

Stipa comata - Stipa viridula - Festuca hallii

Needle and thread grass - Green needle grass - Plains rough fescue Preliminary Rank: S3 

In the Central Parkland, this community is documented by Bradley and Bradley (1977) from one area near the Neutral Hills south of Provost, Alberta. This community is described as a common grassland community occurring on slopes with little to no grade and various aspects. The three species form a codominant, fairly even mixture of Stipa and Festuca. Soil and site conditions are not discussed. This community is ranked $\mathrm{S} 3$ because contains rough fescue (considered provincially threatened), and is a community type that has been reduced drastically in area by agricultural development (A.H. Weerstra pers comm.). It is not well represented in the literature, its provincial abundance is not known and an assessment of structural variability between occurrences is not available.

Stipa curtiseta - Artemisia frigida

Western porcupine grass - Pasture sagewort

Preliminary Rank: S4

In the Central Parkland, this community is described from three areas; one area near Rumsey by Fehr (1982), one area near Dry Island Buffalo Jump Provincial Park by Wroe (1971), and one area near Kinsella, Alberta by Anderson (1972). A. frigida can have a wide range of cover values (15-54\%) and a frequency of $80-100 \%$ between sites (Wroe 1971). Together the dominant species have roughly $70 \%$ cover. Anderson (1972) describes a significant (but unspecified) coverage of Agropyron trachycaulum in this community. This type occupies the area from the tops of the hills to the intermediate slope position and is confined to south and south west-facing, xeric and subxeric sites on the crests and upper slopes of hills. Soils are rapidly and well drained Orthic, Calcareous and Regosolic Dark Brown Chernozems. Other associated species include Selaginella densa, Festuca scabrella, Thermopsis rhombifolia, Koeleria cristata and Anemone patens at unspecified coverages. This community is considered common but it is restricted to south-facing slopes (Wroe 1971, Fehr 1982), possibly due to over-grazing on north-facing slopes.

Stipa curtiseta - Bouteloua gracilis

Western porcupine grass - Blue grama

Preliminary Rank: S5

This community is described by Coupland (1950) from 43 sites in the DarkBrown soil zone which includes the majority of the central and southern Central Parkland subregion of Alberta and Saskatchewan. This community occurs on deep glacial deposits and is also prominent on coarse textured soils in drier areas. It is the characteristic climax community occurring on medium-textured soils developed on undifferentiated glacial till deposits in the moister part of the brown soil zone and the drier part of the dark brown soil zone. In drier areas this community occurs in lower-slope positions and in moister areas occurs on upper to top-slope positions. Specific site 

conditions are not discussed but appear to be variable in moisture and soil texture. An assessment of species and structural variability between occurrences is not available. Associated species, including Artemisia frigida and Gutierrezia sarothrae, can be present but are scarce and low growing. Shrubs including Symphoricarpos occidentalis, Rosa spp. and Elaeagnus commutata are present in areas of increased moisture penetration but when present are not abundant (less than 1\%). The largest portion of the Mixed Prairie area in Canada is occupied by the Stipa - Bouteloua association (Coupland 1950).

Stipa viridula - Poa sandbergii - Carex obtusata

Green needle grass - Sandberg blue grass - Blunt sedge

Preliminary Rank: SU

In the Central Parkland, Meijer and Karpuk (1999) describe a single occurrence of this community in Dillberry Lake Provincial Park. A structural description with coverages of the dominant species is not provided, but this community is found in an area of imperfect drainage where the moisture regime is subxeric and nutrient conditions are mesotrophic. Soils are Gleyed Solonetzic Black Chernozems. Other species present include Grindelia squarrosa, Achillea millefolium, Antennaria parviflora, Bromus inermis and Koeleria macrantha. The presence of Grindelia squarrosa indicates potentially saline conditions. This community is not found elsewhere in the literature and an assessment of provincial abundance is not available.

\section{Temperate or subpolar grasslands on sandy substrate}

\section{CALAMOVILFA LONGIFOLIA SANDY HERBACEOUS ALLIANCE}

Calamovilfa longifolia - Artemisia frigida - Koeleria macrantha - Festuca saximontana - Festuca hallii / Selaginella densa

Sand grass - Pasture sagewort - June grass - Rocky mountain fescue - Plains rough fescue / Prairie Selaginella

Preliminary Rank: S4

In the Central Parkland, this community is described by Fehr (1984) from ten sites near Wainwright, Alberta. It is described as a grassland community where the herb-dwarf shrub cover ranges from $40-70 \%$ on xeric, rapidly drained, sand flats and outwash plains with Dark Brown Chernozemic soils (Fehr 1984). Moisture conditions are xeric to subxeric and nutrient conditions are not discussed. Associated species include Opuntia fragilis and Rhus radicans. This grassland community is found frequently within the Central Parkland upon undulating sand landscapes (H. Loonen pers. comm.). It is considered a common grassland community in the sandhills of the Central Parkland (Fehr 1984) but is restricted in range to sandy areas (A.H. Weerstra pers comm.). This community is not found elsewhere in the literature. 

Natureserve (2001) describes a Calamovilfa longifolia - Carex inops ssp. heliophila (Herbaceous Vegetation) prairie sandreed grassland associated with Koeleria macrantha, Schizachyrium scoparium, and Stipa comata occurring on sandy slopes in the Great Plains of the United States and Canada. This community has two similar dominants (Calamovilfa longifolia and Koeleria macrantha) and similar site conditions, but associated species and a Carex inops co-dominant differentiate this community from Central Parkland types. The Natureserve website refers the reader to Bourgeron and Engelking (1994), Driscoll et al. (1984), Hansen (1985), Hansen et al. (1984), Hansen and Hoffman (1988), Hansen and Whitman (1938), Hirsch (1985), and USFS (1992) for information on Calamovilfa types described from the USA, all of which appear to be different in composition to the Parkland type described above.

\section{MUHLENBERGIA ASPERIFOLIA SANDY HERBACEOUS ALLIANCE}

Muhlenbergia asperifolia - Scirpus nevadensis - Distichlis stricta

Scratch grass - Nevada bulrush - Salt Grass

Preliminary Rank: S2

This community is described by Wallis (1990) as a hypersaline dry meadow type occurring generally within the Grassland and Parkland Regions of Alberta. In this type Muhlenbergia asperifolia occasionally dominates to the exclusion of Scirpus nevadensis and Distichlis stricta but there is usually a mixed community of these three species (Wallis 1990). A comparison of species and structural variability between occurrences is not possible. Specific soil types and site conditions are not discussed, but this community occurs where sandy soils have been disturbed. Muhlenbergia asperifolia is currently ranked S2 on the Alberta Vascular Plant Tracking List (ANHIC 2001) and Scirpus nevadensis is not considered common in the province. Although not documented, the frequency of these two species occurring together as a community would most likely be very localized (Wallis 1990, C. Wallis pers comm.). This community is not described elsewhere in the literature.

\section{PUCCINELLIA NUTTALLIANA SANDY HERBACEOUS ALLIANCE}

Puccinellia nuttalliana - Distichlis stricta

Nuttall's salt meadow grass - Salt grass

Preliminary Rank: S4

This community is described by Wallis (1990) as a hypersaline dry meadow type occurring generally within the Grassland and Parkland Regions of Alberta. It is described as occurring on open, sandy sites ecotonal between bands of Puccinellia nuttalliana and Scirpus nevadensis with the dominant 

species occurring at unspecified coverages. Specific soil and site conditions are not discussed and an assessment of structural variability between occurrences is not available. Associated species include Hordeum jubatum and Agropyron smithii. This is considered a common community in Alberta (C. Wallis pers comm.) and continuous stands of Puccinellia nuttalliana are commonly found associated with Distichlis stricta in British Columbia (Parish et al. 1996). Distichlis stricta is ranked S4 in Alberta, so this is reflected in the community rank. This community is not found elsewhere in the literature.

\section{SPARTINA GRACILIS HERBACEOUS ALLIANCE}

Spartina gracilis - Agropyron smithii

Alkali cord grass - Western wheat grass

Preliminary Rank: S2S3

This community is described by Wallis (1990) as a saline dry meadow type occurring generally within the Grassland and Parkland Regions of Alberta. Specific site and soil conditions are not discussed, but this community occurs on open, sandy sites between driest portion of the (unspecified) halophytic communities and the (unspecified) semi-halophytic communities occurring further upslope (Wallis 1990). This community is not represented elsewhere in the literature. This type is not considered common and grows in narrow bands in very specific saline/sandy habitat types limiting its extent (C. Wallis, pers comm.). Information is not available to assess species or structural variability between occurrences.

\section{STIPA CURTISETA SANDY HERBACEOUS ALLIANCE}

Stipa curtiseta - Koeleria macrantha - Agropyron trachycaulum / Cladina mitis Western porcupine grass - June grass - Slender wheat grass / Yellow reindeer lichen Preliminary Rank: SU

In the Central Parkland, this community is described by Meijer and Karpuk (1999) from three sites in Dillberry Lake Provincial Park. Lichen cover averages $72 \%$, with grass cover inversely related to lichen cover, ranging from 6 to $25 \%$. Forb cover is limited. It is associated with shallow, south-facing slopes in sandy areas of dune fields. It is found on south to south-east aspects with rapid drainage and submesotrophic nutrient conditions. Moisture conditions are xeric and soils are Ortho Regisolic to Orthic Dark Brown Regisols. Associated species include Arctostaphylos uva-ursi, Juniperus horizontalis and Symphoricarpos occidentalis at unspecified coverages. This community is not found elsewhere in the literature, so provincial abundance of this community type is not known.

\section{Temperate or subpolar seasonally flooded grasslands}





\title{
HORDEUM JUBATUM SEASONALLY FLOODED HERBACEOUS ALLIANCE
}

\author{
Hordeum jubatum \\ Foxtail barley \\ Preliminary Rank: S4
}

In the Central Parkland of Alberta, this community type is described by Fehr (1982) from near Rumsey, and by Wallis (1990) as a saline dry meadow type occurring generally within the Parkland and Grassland Regions of Alberta. This community type occurs as a wide band of vegetation around saline sloughs. It characterizes sites on higher margins of the wetlands where more permanent cover has been destroyed by periodic flooding and desiccation (Wallis 1990). In Alberta, Hordeum jubatum forms almost pure stands with covers up to $40 \%$. This community is described elsewhere (see below) and is likely not uncommon. An assessment of structural variability between occurrences of this type in Alberta is not possible with current information. This community is ranked S4 to coincide with its global rank assigned by The Nature Conservancy (Natureserve 2001).

Natureserve (2001) describes a similar community type with similar site conditions reported from Montana, Utah, generally from the Great Plains of the United States, and within western Canada (ranked G4 by The Nature Conservancy). However, references for this community type in the literature are not strong (undergraduate projects, draft reports). The vegetation is dominated by short and medium-tall graminoids (unspecified species) with a total vegetation cover of nearly $100 \%$. Shrubs are usually absent from this community (Natureserve 2001). In Utah, stands are found in lowlands with moderately to strongly saline soils. The topography is flat and the soils are often flooded or saturated in the spring. In Montana, this community is a seasonally flooded subsaline wetland type, and a drawdown phase of seasonal and semipermanent brackish and subsaline marshes (Heidel et al. 2000, Thompson 1994).

\section{PUCCINELLIA NUTTALLIANA HERBACEOUS ALLIANCE}

\section{Puccinellia nuttalliana \\ Nuttall's salt meadow grass \\ Preliminary Rank: S3}

In the Central Parkland, this community is described by Fehr (1982) from one site in the Rumsey area, and as occurring generally as a saline emergent marsh or a hypersaline dry meadow within the Parkland and Grassland Regions of Alberta by Wallis (1990). This community is typified by almost pure stands of Puccinellia nuttalliana with a coverage of $<20 \%$. It can be found on fine, sandy loam to heavy clay textured saline meadow soils, and subhydric saline depressions, where it occurs in a wide band around saline sloughs (Fehr 1982, 

Wallis 1990). Specific site conditions are not discussed. Other species that can be present include Triglochin maritima, Salicornia europaea, Scirpus nevadensis, Distichlis stricta, Suaeda calceoliformis and Hordeum jubatum.

As a species, Puccinellia nuttalliana can be found throughout central and southern Alberta (Moss 1983), but it is not well represented in the Alberta literature as a community type. Although not formally considered rare in the province, this community type is ranked G3 by The Nature Conservancy (Natureserve 2001) because it has specific habitat needs; this community requires moist soils of intermediate salinity in seasonally wet meadows, and has been impacted by water diversion, livestock grazing, and land conversion in many places (Ungar 1974).

Elsewhere, similar communities of Puccinellia nuttalliana are found in the Great Plains and intermountain region, extending from Alberta and Saskatchewan to Nebraska, and west to Montana, Utah and California (Heidel et al. 2000). This community is characterized by the dominance of Puccinellia nuttalliana in the graminoid layer. Trace amounts of Distichlis stricta or Hordeum jubatum can be associated with this community. The forb layer is relatively sparse and is often composed of Salicornia rubra or Triglochin maritima. Topographic position and saline conditions of these communities are very similar to Central Parkland types.

\section{PHALARIS ARUNDINACEA HERBACEOUS ALLIANCE}

Phalaris arundinacea - Carex atherodes - Calamagrostis stricta

Narrow reed grass - Awned sedge - Reed canary grass

Preliminary Rank: S5

This community is described from one site near Sylvan Lake on the western edge of the Central Parkland by Griffiths and Griffiths (1987a). Quadrat coverages of Phalaris arundinacea and Carex atherodes were approximately $25-50 \%$, with Calamagrostis stricta at approximately 6-15\%. This community is considered "mature" and occurs along shorelines beyond the limits of willow growth where water depth does not exceed $20 \mathrm{~cm}$. Soils are Hydric Humisols and deadfall is present at trace amounts. Associated species include Carex aquatilis and, where water is deeper, Sagittaria cuneata and Eleocharis palustris all at levels of $<5 \%$. Adjacent communities further from the water include "willow shrubbery", Typha latifolia followed by a broad, monoculture zone of Scirpus validus. This community is considered a common community type around lakes and sloughs in Alberta (G. Griffiths pers comm.) but is not well represented in the literature. Because this type is only described from one site, an assessment of species and structural variability between occurrences is not possible.

Temperate or subpolar intermittently flooded grasslands 

CALAMAGROSTIS INEXPANSA INTERMITTENTLY FLOODED HERBACEOUS ALLIANCE

Calamagrostis inexpansa - Juncus balticus

Northern reed grass - Wire rush

Preliminary Rank: S5

In the Central Parkland, this community is described by Meijer and Karpuk (1999) from two sites in Dillberry Lake Provincial Park. Because this type is only described from two sites in the same area, an assessment of species and structural variability between occurrences is not possible. Coverages for dominant species are not provided. This community is associated with receding lakeshores Orthic Regosolic and Rego Gleysolic soils in poorly drained sites with mesic to hygric moisture regimes and permesotrophic nutrient conditions. Associated species include Populus balsamifera, Salix bebbiana, Salix candida, Solidago canadensis and Carex praegracilis. The Calamagrostis inexpansa-Juncus balticus community type is not described elsewhere in the literature.

\section{HORDEUM JUBATUM INTERMITTENTLY FLOODED HERBACEOUS ALLIANCE}

Hordeum jubatum - Puccinellia nuttalliana

Foxtail barley - Nuttall's salt meadow grass

Preliminary Rank: S4

In the Central Parkland, this community is described by Griffiths et al. (1996) from one site near Lister Lake, Alberta. It is a patchy grass community that occurs under beach ridges exposed for more than two years. Specific site and soil conditions are not discussed. Hordeum jubatum is dominant or codominant and can almost reaches monocultures in some areas. Hydrological regime differentiates this community from the $H$. jubatum community described earlier (i.e. this community is not seasonally flooded). Associated species can include Scirpus pungens, Eleocharis palustris, Juncus balticus, Rumex maritimus, Sonchus arvensis, Aster brachyactis, Ranunculus cymbalaria and Taraxacum officinale at unspecified coverages. This community is not threatened, but somewhat limited in extent as it is found only from oligohaline lakes with fluctuating water levels (e.g. Beaverhill Lake, G. Griffiths pers comm.). Because it is only described from one site, an assessment of species and structural diversity between occurrences is not possible.

(Herbaceous)

Composites

Oblong, spatulate-leaved 

Temperate or subpolar composite grasslands

ANTENNARIA PARVIFOLIA HERBACEOUS ALLIANCE

Antennaria parvifolia - Artemisia frigida - Koeleria macrantha

Small leaved everlasting - Pasture sagewort - June grass

Preliminary Rank: SU

In the Central Parkland, this community is described by Fehr (1984) from ten sites near Wainwright (David Lake), Alberta. Fehr (1984) estimated percent cover for the three main species at $35 \%, 20 \%$, and $20 \%$, respectively. Other species present can include Juncus balticus (15\%), Carex spp. (10\%) and Poa $s p p .(10 \%)$. The variability in species and structure between occurrences is not reported. This community can be found on hilltops and dry areas. Specific soil and site conditions are not discussed. The absence of important forage species (Agropyron trachycaulum, Bouteloua gracilis, etc.) is a reflection of the heavy grazing this community type receives. This community is not reported elsewhere in the literature and its provincial abundance is unknown.

(Herbaceous)

(Composites)

Twice-pinnate leaves

\section{Temperate or subpolar composite grasslands}

\section{ARTEMISIA FRIGIDA HERBACEOUS ALLIANCE}

Artemisia frigida / Koeleria macrantha - Carex obtusata

Pasture sagewort / June grass - Blunt sedge

Preliminary Rank: SU

In the Central Parkland, this community is described by Meijer and Karpuk (1999) from two sites in Dillberry Lake Provincial Park. Coverages of the dominant species are not provided, so an assessment of variability between occurrences is not possible. It is described as being closely associated with south-facing slopes of glaciofluvial origin. It is found on xeric to very xeric sites with very rapid drainage and Orthic and Rego Dark Brown Chernozemic soils. Associated species can include Symphoricarpos occidentalis, Heterotheca villosa, Thermopsis rhombifolia, and Agropyron trachycaulum at unspecified amounts. This community is not represented elsewhere in the literature and its provincial abundance is not known.

(Herbaceous)

(Composites) 



\title{
Leaves large, petioled
}

Temperate or subpolar permanently flooded composite wetlands POLYGONUM AMPHIBIUM PERMANENTLY FLOODED HERBACEOUS ALLIANCE

\author{
Polygonum amphibium \\ Water smartweed \\ Preliminary Rank: S4
}

This wetland vegetation type is not formally documented from the Central Parkland of Alberta, but is known to occur in shallow water along the edges of ponds and lakes, with floating-leaved aquatic forbs covering roughly $30 \%$ of the water's surface (Kunze 1994). Polygonum amphibium often forms dense, nearly monotypic stands. Lemna minor, Potamogeton natans, Sagittaria spp., Spirodela polyrhiza and Wolffia spp. are occasionally present. This community is currently on the Alberta Plant Community Tracking List (Allen 2001) and is ranked SU. Little information is available for Alberta communities. The species Polygonum amphibium is noted as widespread in Alberta (Moss 1983) and the occurrence of this species as a community type is not considered rare (C. Wallis pers comm.).

Johnson $(1939,1941)$ found this community in Colorado around montane lakes with significant sediment deposition. In Montana, Heidel et al. (2000) note this community from disturbed agricultural sites that are seasonally inundated and slightly brackish (ranked S? for Montana). It is also found around reservoirs, ponds and other wet areas in Montana.

\section{Shrubland}

\section{Deciduous}

\section{Broad-leaved}

\section{Temperate or subpolar cold-deciduous shrubland}

\section{ELAEAGNUS COMMUTATA SHRUBLAND ALLIANCE}

\section{Elaeagnus commutata \\ Silverberry \\ Preliminary Rank: S2}

In the Central Parkland, this community is described from three different sites; one site in Dillberry Lake Provincial Park by Meijer and Karpuk (1999), one site near Rumsey by Fehr (1982) and one site in Dry Island Buffalo Jump by Bradley and Bradley (1972). In this community Elaeagnus commutata forms a shrub layer of approximately $50 \%$ cover (Fehr 1982). This type occurs as low shrublands and shrubby meadows along the perimeter of saline lakes 

adjacent to marshes or graminoid meadows. It occupies the middle and lower positions of mesic to submesic slopes, and is found in areas that are moderately to well drained with northern or southern aspects often in proximity to alkaline water bodies. This shrubland community possesses xeric moisture conditions and submesotrophic nutrient conditions with Orthic Dark Brown soils. Common associates include Symphoricarpos occidentalis (potentially reaching co-dominance in some cases according to Fehr (1982)), Rosa acicularis, Carex spp., Calamovilfa longifolia and Agropyron trachycaulum at unspecified (but assumed trace) levels. Characteristic herbs can include Hackelia americana, Galium boreale and Rorippa islandica all at coverages $<5 \%$.

Fehr (1982) describes an Elaeagnus commutata - Symphoricarpos occidentalis community in the Rumsey area of Alberta. Meijer and Karpuk (1999) describe an Elaeagnus commutata community in Dillberry Lake Provincial Park. This shrubland community is typically well developed and dense with a poorly developed herb-dwarf shrub layer. In terms of abundance, Bradley and Bradley (1977) considered E. commutata to be more abundant as one goes south of the Rumsey area and this community is considered as common in the Central Parkland of Alberta ( $\mathrm{H}$. Loonen pers comm.). The species Elaeagnus commutata can be found throughout central and southern Alberta, but the occurrence of this species as a community type is not well documented. The Nature Conservancy (Natureserve 2001) ranks Elaeagnus commutata as G2, requiring an S2 rank for Alberta.

Elsewhere, similar communities of silverberry shrubland are reported in Montana east of the continental divide with shrub coverages around $10 \%$ and a Stipa comata understory of up to $70 \%$ (Heidel et al. 2000). Natureserve (2001) describes an Elaeagnus commutata shrubland, but it is unclear whether this is the same community found in Alberta because the site conditions and species coverages are not adequately described. Elaeagnus commutata Shrubland is considered a minor community type forming narrow stringers on stream terraces in northern Montana, east of the Continental Divide (Natureserve 2001).

Elaeagnus commutata / Symphoricarpos occidentalis - Rosa woodsii / Poa palustris Silverberry / Snowberry - Common wild rose / Fowl bluegrass Preliminary Rank: SU

In the Central Parkland, this community is described by Fehr (1984) from one site near Wainwright, Alberta. Unlike the Elaeagnus commutata cover type described above, this community has a tall shrub layer of Symphoricarpos occidentalis and a characteristic component of Rosa woodsii. This type can be found in subxeric and submesic locations where drainage is good (Fehr 1984). It has a well developed low shrub layer $(75-80 \%$ cover) and occurs on Dark Brown Chernozemic soils. Other species occurring at levels less than 

5\% include Achillea millefolium, Thermopsis rhombifolia, Disporum trachycarpum, Fragaria virginiana, Ribes oxyacanthoides and Galium boreale. This community is only documented once in the literature, preventing any assessment of structural variability between occurrences, and its provincial abundance is therefore not certain.

\section{POPULUS TREMULOIDES SHRUBLAND ALLIANCE}

Populus tremuloides - Amelanchier alnifolia - Prunus virginiana / Rosa spp. Trembling aspen - Saskatoon - Choke cherry / Rose spp.

Preliminary Rank: S5

In the Central Parkland, this community is described by Meijer and Karpuk (1999) from three sites in Dillberry Lake Provincial Park associated with steep, north aspects. This community is a young, shrub-level successional stage of regenerating aspen in areas where the canopy has opened from natural disturbance (e.g. windthrow, beaver, natural forest edge). Drainage is rapid, moisture regimes are submesic, and nutrient conditions are typically submesotrophic to mesotrophic. Soils tend to be Rego Dark Brown Chernozems, Orthic Regosols and Cumulic Regosols. Other species present can include Rubus idaeus, Ribes oxyacanthoides, Aralia nudicaulis, Smilacina stellata, and Schizachne purpurascens. We have observed this community in upland clearings and well-drained, open woods in the Boreal and Foothills Regions of Alberta. This community was not found elsewhere in the literature so an assessment of structural variability between occurrences is not possible.

\section{PRUNUS VIRGINIANA SHRUBLAND ALLIANCE}

Prunus virginiana - Amelanchier alnifolia / Agropyron trachycaulum - Poa pratensis Choke cherry - Saskatoon / Slender wheat grass - Kentucky blue grass Preliminary Rank: S5

In the Central Parkland, this community is described by Griffiths et al. (1997) from one site in the Blackfoot Provincial Recreation Area. It is described as "dryland shrubbery"; cleared areas without aspen saplings where the low shrubs grow mixed with tall grasses. Soil conditions are not discussed, but this type was located on a steep, south-facing slope. This community is considered common in the parklands of the prairie provinces, but becomes restricted to south-facing slopes in forested areas where it is described by Griffiths et al. (1997). This dryland shrubbery can be distinguished from aspen-dominated shrubland and beaver-cleared areas by the absence of aspen suckers. Looman (1983) classifies this vegetation in the alliance "Prunion melanocarpae", but does not discuss abundance or variation within occurrences. 



\section{ROSA ACCICULARIS SHRUBLAND ALLIANCE}

Rosa acicularis - (shrub) / Solidago spp.

Prickly rose

Preliminary Rank: SU

In the Central Parkland, this community is described by Meijer and Karpuk (1999) from one site in Dillberry Lake Provincial Park. A structural description is not provided for this community. It can be found on subxeric, west-facing slopes with rapid drainage, Rego Dark Brown soils, and submesotrophic nutrient conditions. Associated species can include Amelanchier alnifolia, Prunus virginiana, Solidago spp., Heterotheca villosa and Agropyron spp at unspecified (but assumed trace) amounts. This rosedominated community is not found elsewhere in the literature and its provincial abundance is not certain.

Rosa acicularis - Rubus idaeus / Lathyrus venosus

Prickly rose - Wild red raspberry / Purple pea vine

Preliminary Rank: S5

In the Central Parkland, this community is described by Timoney and Robinson (1998) from nine sites in the Blackfoot Provincial Recreation Area. This community forms when beavers, pathogens, or insect outbreaks remove large portions of the forest canopy allowing shrub layers to develop. Cover values for the dominant species are not provided. It is a beaver-dependent shrubland type typical of well drained slopes near beaver ponds. It is found in areas of submesic to subhygric moisture regimes, in Orthic Grey Luvisolic soils. Associated species include Symphoricarpos occidentalis, Amelanchier alnifolia, Prunus virginiana, Salix bebbiana, and Calamagrostis canadensis at unspecified (but assumed trace) amounts. It is differentiated from the Rosa acicularis - (shrub) / Solidago spp. community described above because this community occurs in moister site conditions, different soil types (i.e. not Rego Dark Brown) and it is characterized by the presence of Rubus idaeus as a dominant species. We have observed this community on similar site conditions associated with mature aspen forest openings in the Central and Dry Mixedwood subregions of Alberta. Although a formal assessment of its provincial abundance is not available, this community should not be considered a rare type.

\section{SALIX SPP. SHRUBLAND ALLIANCE}

Salix petiolaris / (low shrubs and herbs)

Basket willow

Preliminary Rank: S5 

In the Central Parkland, this community is described by Fehr (1982) from one site near Rumsey, and by Wroe (1971) from one site near Dry Island Buffalo Jump, Alberta. A description of the structure and cover of the dominant species is not provided. It occupies moist banks around sloughs, forms rings or clumps around mesic depressions and is generally restricted to moist areas with rolling topography. It occurs in mesic to hydric moisture regimes with moderately to poorly drained Rego and Orthic Humic Gleysolic soils. This community is surrounded to varying degrees by Populus tremuloides forest (community type not specified). Salix lutea and Populus balsamifera are sometimes present as trees. Associated shrubs and herbs can include Rosa woodsii, Amelanchier alnifolia, Symphoricarpos occidentalis, Poa palustris, Epilobium angustifolium, Beckmannia syzigachne, Calamagrostis spp., Carex rostrata and Carex atherodes at unspecified levels.

Fehr (1982) describes a Salix petiolaris / Rosa woodsii / Sonchus spp. community from near Rumsey, Alberta, and Wroe (1971) describes a Salix petiolaris / Rosa woodsii / Sonchus arvensis community from near Dry Island Buffalo Jump Provincial Park. Both types occur on identical site conditions with the same associated species and are considered the same community type in this report. This community is not documented elsewhere in the literature. Salix petiolaris is common in central Alberta (Moss 1983) and when present often forms communities as thickets or clumps in wet areas, but a formal assessment of abundance is not available for this community.

\section{SYMPHORICARPOS OCCIDENTALIS SHRUBLAND ALLIANCE}

Symphoricarpos occidentalis

Buckbrush

Preliminary Rank: S4

In the Central Parkland, this community is described from several locations; two sites in Dillberry Lake Provincial Park (Meijer and Karpuk 1999), one site near Kinsella, one site near Rumsey (Fehr 1982), and one site near Dry Island Buffalo Jump (Wroe 1971). In the Central Parkland, this community is a dense shrubland ranging in size from 0.004 to 0.30 ha (Wroe 1971) where total shrub cover averages $80 \%$ (range $75-95 \%$ ). A large quantity of dead stems of Symphoricarpos occidentalis can be an important component of this community. It occupies shallow depressions on the grassland, and in many instances positions of higher elevations adjacent to the aspen communities. This community can be found on north/east and south/west-facing slopes on rapidly drained sites with submesotrphic nutrient conditions, along the perimeters of naturally open woodlands or in association with fescue grasslands. It is associated with dry conditions, and Orthic and Rego Dark Brown Chernozemic soils. Associated species include Elaeagnus commutata, Rosa acicularis, Prunus virginiana, Artemisia frigida and Koeleria 

macrantha. Rosa woodsii and Ribes oxyacanthoides can also be present all at $<10 \%$ cover.

Anderson and Bailey (1980) mention a similar community found in Populus tremuloides parkland from east-central Alberta associated with Agropyron spp., Stipa spartea and Elaeagnus commutata. Fehr (1982) and Wroe (1971) both describe this community from the Rumsey area. All of these types possess the same site conditions and associated species and are all considered the same community type in this report. The Nature Conservancy (Natureserve 2001) has ranked this community type as G4, and it is therefore ranked S4 in Alberta.

Elsewhere, similar Symphoricarpos occidentalis communities are reported from Saskatchewan, Missouri, and Montana in mesic depressions, typically surrounded by upland grassland associations (Heidel et al. 2000). This community type has also been described for Montana, North Dakota (Hansen et al. 1984, Hansen et al. 1990) and is reported as common in the Saskatchewan parkland (Coupland et al. 1953). Natureserve (2001) describes a western snowberry shrubland from the western tallgrass and northern Great Plains of the United States and Canada where Symphoricarpos occidentalis is the predominant species in the shrub layer and at times forms almost monotypic stands. Associated species occurring at the fringe of this community include Rosa woodsii, Rhus aromatica and Prunus virginiana. The herbaceous layer is poorly represented where the shrubs are dense but can include Artemisia ludoviciana, Solidago spp., Poa pratensis and Achillea millefolium. This type is frequently observed in heavily grazed meadows and prairies. It is tolerant of both grazing and fire (Hansen and Hoffman 1988), and is under no threat from human activities (Natureserve 2001).

\section{Symphoricarpos occidentalis / Antennaria parvifolia - Festuca hallii}

Buckbrush / Small leaved everlasting - Plains rough fescue

Preliminary Rank: SU

In the Central Parkland, this community is described from one site in the Wainwright Ecological Reserve by Pearson Timberline (1993). The inclusion of Antennaria parvifolia and Festuca hallii as community dominants differentiates this community from the Symphoricarpos occidentalis community described above. A description of coverage or structure of the dominant species is not provided. This community is found on sandy, outwash plains with Dark Brown Chernozem and Humic Gleysolic (calcareous) soils. Slopes can range from $0-10 \%$ in all directions, sites are well to moderately-well drained, and nutrient conditions are submesic to mesic. Other shrub species can include Elaeagnus commutata and Rosa spp. Forbs and grasses can include Selaginella densa, Carex spp. and Stipa spartea. This community is not represented elsewhere in the literature and its provincial abundance is unknown. 

Temperate or subpolar permanently flooded cold-deciduous shrubland BETULA PUMILA PERMANENTLY FLOODED SHRUBLAND ALLIANCE

Betula pumila / Carex aquatilis

Dwarf birch / Water sedge

Preliminary Rank: S5

In the Central Parkland, this community is described by Meijer and Karpuk (1999) from one site in Dillberry Lake Provincial Park. A description of dominant-species structure or coverage is not provided. It is described as a classic fen possessing a floating mat of organic material greater than $140 \mathrm{~cm}$ in thickness. Soils are Hydric Humisols. Drainage is very poor, moisture conditions are hydric and nutrient conditions are eutrophic. Associated species include Salix serissima, Carex aquatilis and Drepanocladus spp. Floating fens are considered unusual in the Central Parkland (Meijer and Karpuk 1999) but we have observed this community in the Boreal Region of Alberta, and similar types are described elsewhere.

A Betula pumila - Salix spp. community type is described from southwestern Alberta by Archibald et al. (1996). This "dwarf birch / sedge / peat moss" community occurs in similar site conditions and can include Larix laricina, Carex spp. and Sphagnum spp. A Betula pumila - Salix spp. community type is described from the northern tallgrass prairie and adjacent prairie-forest border regions of the upper midwestern United States, where surface water $\mathrm{pH}$ is neutral to somewhat alkaline and has moderate nutrient levels (Natureserve 2001). It is typically found on relatively shallow peat. This community has a shrub layer with $25-70 \%$ cover, abundant herbaceous species, and sparse to abundant mosses. Associated species include Calamagrostis canadensis, Calamagrostis stricta, Carex aquatilis, Carex lasiocarpa, Eriophorum angustifolium, Euthamia graminifolia, Lobelia kalmii, Lycopus uniflorus, and Triadenum fraseri. Valid comparisons of this community type to the type found in the Central Parkland difficult without identifying the Salix to species.

\section{SALIX PYRIFOLIA PERMANENTLY FLOODED SHRUBLAND ALLIANCE}

Salix pyrifolia - Betula neoalaskana / Ledum groenlandicum - Calamagrostis canadensis / Sphagnum warnstorfii

Balsam Willow - Alaskan birch / Labrador tea - Marsh reed grass / Warnstorf's peat moss

Preliminary Rank: S5

In the Central Parkland, this community is described by Griffiths et al. (1997) from one site in the Blackfoot Provincial Recreation Area. This community is found in oligotrophic, perched morainal depressions and on bog margins 

sometimes intergrading with taller swamp vegetation. Associated species, specific site conditions and soil types are not discussed, however, the dominance of balsam willow would indicate relatively oligotrophic conditions. Griffiths et al. (1997) describe this community as a Balsam Willow Carr; the term "Carr" used for fens with extensive shrub coverage but with few or no trees. This community is considered common throughout the Boreal and Parkland Regions of Alberta (Griffiths et al. 1997) but is not discussed elsewhere in the literature.

Salix pyrifolia / Carex utriculata

Balsam willow / Greater beaked sedge

Preliminary Rank: SU

In the Central Parkland, this community is described by Griffiths and Griffiths (1987b) from one site near Onoway, Alberta. This balsam willow Carr occurs with a dense and diverse herb coverage dominated by Carex utriculata. Variation in water levels prevents willow colonization from supressing herb growth. Specific site and soil conditions are not discussed, but other herbaceous associates, depending on water depth variation, include Glyceria grandis, Polygonum amphibium and Lemna minor. This community is not well represented in the literature and its provincial abundance is not known.

\section{Temperate or subpolar semi-permanently flooded cold-deciduous shrubland}

\section{SALIX PETIOLARIS SEMI-PERMANENTLY FLOODED SHRUBLAND}

Salix petiolaris - Salix planifolia / Carex utriculata

Basket willow - Tea-leaved willow / Greater beaked sedge

Preliminary Rank: S5

In the Central Parkland, this community is described by Griffiths and Griffiths (1987b) from one site near Onoway, Alberta. This community occurs in flooded areas where Salix pyrifolia is rare or entirely lacking. Specific site and soil conditions are not discussed and an estimation of the coverage of dominant species is not provided. Vegetation around the periphery of this community can include Salix petiolaris, Carex aquatilis, Glyceria grandis, Scirpus microcarpus, Galium trifidum, Lysimachia thyrsiflora, Bidens cernua, Lemna minor and Calamagrostis canadensis at unspecified levels. This community is considered as common around lakes and sloughs in Alberta (G. Griffiths pers comm.) but it is not found elsewhere in the literature.

Salix petiolaris / Juncus balticus

Basket willow / Wire rush

Preliminary Rank: S5 

In the Central Parkland, this community is described by Griffiths et al. (1996) from one site near Lister Lake, Alberta. This community is described as willow shrubbery; a stable edaphic climax community on land with a water table too high for balsam poplar to reach maturity. Site and soil conditions are not discussed. Associated species include Juncus balticus, Calamagrostis stricta and Poa pratensis at unspecified levels. The moss Drepanocladus aduncus can sometimes be present. This community is considered common around lakes and sloughs in Alberta (G. Griffiths pers comm.) but it is not found elsewhere in the literature.

\section{Temperate or subpolar cold-deciduous shrubland on sandy substrate}

\section{POPULUS TREMULOIDES SANDY SHRUBLAND ALLIANCE}

Populus tremuloides / Juniperus horizontalis / Cladina mitis Trembling aspen / Creeping juniper / Yellow reindeer lichen Preliminary Rank: SU

In the Central Parkland, this community is described from three sites; one site near Wainwright (Fehr 1984) and three in Dillberry Lake Provincial Park (Renewable Resources Consulting Services 1974, Meijer and Karpuk 1999). Fehr (1984) noted a well-developed shrub layer (approximately $24 \%$ cover), aspen being the dominant species, averaging approximately $2 \mathrm{~m}$ in height. Juniperus horizontalis averages $20 \%$ cover with Cladina mitis averaging $33 \%$ cover (Fehr 1984). This type is found on inter-dune depressions, on the upper positions of shallow, south-facing slopes with rapid drainage. Soils are Orthic Dark Brown to Orthic Regisols with xeric moisture regimes and submesotrophic nutrient conditions. Other shrub species with lower abundances ( $<7 \%)$ can include Betula papyrifera, Rosa acicularis, Salix bebbiana, Gallium boreale, Artemisia campestris, Agropyron trachycaulum and Stipa curtiseta. The herb-dwarf shrub layer averages $40 \%$ cover with Juniperus horizontalis dominant, but also containing Selaginella densa and Calamovilfa longifolia. Bryoides form an extensive ground mat in these stands (30-60\% cover according to Fehr 1984) consisting of Cladina mitis (the dominant), Cetraria nivalis, Cladonia uncialis, Cladonia pyxidata and Cetraria ericetorum. This community is considered common on historically windblown and recently stabilized steep slopes and blowouts of the choppy sand hill terrain of the Central Parkland (H. Loonen, pers comm.), however, it is not well represented in the literature so its provincial abundance is not known.

\section{SYMPHORICARPOS OCCIDENTALIS SANDY SHRUBLAND ALLIANCE}

Symphoricarpos occidentalis - Rosa arkansana / Juniperus horizontalis

Buckbrush - Prairie rose / Creeping juniper

Preliminary Rank: SU 

In the Central Parkland, this community is described by Renewable Resources Consulting Services (1975) from one site in Dillberry Lake Provincial Park. This community type is described from the grassland areas as scattered patches of Symphoricarpos occidentalis and Rosa arkansana with vigorous mats of creeping juniper. Specific site and soil information is not discussed. This community is described only briefly in the literature so its overall abundance is not clear and there is no information on community structure or dominant species abundance.

\section{Sparse}

\section{Xeric sandy soil}

Dunes and blowouts

\section{Temperate or subpolar sparse graminoids on sand}

Calamovilfa longifolia - Sporobolus cryptandrus - Koeleria macrantha-Carex obtusata

Sand grass - Sand dropseed - June grass - Blunt sedge

Preliminary Rank: S3

In the Central Parkland, this community is described by Meijer and Karpuk (1999) from three sites in the southern half of Dillberry Lake Provincial Park. This community can be found on sand dunes or active blowouts. It is generally located on south to west-facing aspects with Regosolic soils and sparse vegetation cover. Conditions are typically xeric with rapid drainage and oligotrophic to submesotrophic nutrient conditions. Juniperus horizontalis and Heterotheca villosa can also be present. This community is not well represented in the literature. It is restricted to active blowouts and consequently has a limited range (Meijer and Karpuk 1999).

\section{Temperate or subpolar sparse cold-deciduous shrubs on sand}

Populus tremuloides / Juniperus horizontalis

Trembling aspen / Creeping juniper

Preliminary Rank: SU

This regenerating aspen community was described from one site in Dillberry Lake Provincial Park on a shallow, south-facing slope with rapid drainage (Meijer and Karpuk 1999). It is found on Orthic Dark Brown soils with subxeric moisture conditions and submesotrophic nutrient conditions. Trace grasses, forbs and lichens can include Solidago missouriensis, Calamovilfa longifolia, Carex obtusata and Cladina mitis. This community is not found elsewhere in the literature and its provincial abundance is unknown. 

Populus tremuloides - Prunus virginiana / Juniperus horizontalis / Selaginella densa Trembling aspen - Choke cherry / Creeping juniper / Prairie Selaginella Preliminary Rank: S3

This community type, described from one site in the Wainwright area, can be found on sand dunes with Regosolic soils, rapid drainage, and xeric to very xeric moisture regimes (Pearson Timberline 1993). Slopes can range from 0$50 \%$ on south or southwest aspects. Aspen growth is stunted to shrub height. Carex siccata, Calamovilfa longifolia and Elymus canadensis can also be present. This community is not found elsewhere in the literature. It has a limited range on south-facing sand dunes and is thus ranked S3. Because it is only documented from one site, and because the coverage and structure of the community is not described, an assessment of structural variability between occurrences is not possible.

\section{Temperate or subpolar sparse evergreen shrubs on sand}

Juniperus horizontalis / (Koeleria macrantha) / Cladina mitis

Creeping juniper / (June grass) / Yellow reindeer lichen

Preliminary Rank: S1S2

In the Central Parkland, this community is described by Fehr (1984) from one site near Wainwright, Alberta. Fehr (1984) estimated that Juniperus horizontalis forms roughly $16 \%$ cover, with Koeleria macrantha and Cladina mitis forming $1.8 \%$ and $27 \%$ cover, respectively. It is found in stable blowout areas of sand dunes. It occurs in xeric to very xeric areas with southern aspect, rapid drainage, sparse vegetative cover, and Orthic Regosolic soils. Other lichens present can be Cetraria ericetorum and Cetraria nivalis. The moss Tortula ruralis can also be present. Because it occurs on active blowouts in sand dune areas, this community is restricted in area. It is not found elsewhere in the literature and is currently on the ANHIC plant community tracking list with a rank of S1S2 (Allen 2001).

\section{Lake and slough edges \\ Saline wetlands}

\section{Saline wetland sparse herbaceous vegetation}

Salicornia europaea

Samphire

Preliminary Rank: S2

This community is described by Wallis (1990) as occurring generally within the Grassland and Parkland Regions of Alberta, characteristic of saline Gleyed Regosolic soils at the edge of the non-vegetated portion of hypersaline emergent marshes. It is typified by a band of pure $S$. europaea with less than 

$25 \%$ cover. Associated species are Hordeum jubatum, Triglochin maritima, Chenopodium rubrum and Suaeda calceoliformis. This community is not well represented in the literature for Alberta and is included on the Alberta Plant Community Tracking List with a rank of S2 (Allen 2001).

The Nature Conservancy has ranked this community G2. They describe it as being associated with highly alkali wetlands or semipermanent alkali lakes in the northern Great Plains and Great Basin of the United States and adjacent Canada (Natureserve 2001). It often borders intermittent open water or is found on the exposed mud of alkali flats. Salicornia europaea may make up to $100 \%$ of the vegetation within these areas. Other associated species can include Puccinellia nuttalliana, Distichlis spicata, Hordeum jubatum, Triglochin maritima, Chenopodium rubrum, and Suaeda calceoliformis. This type occurs over a broad geographic range and has been recorded from Nebraska, South Dakota, North Dakota, Minnesota, Montana, Colorado, and north into Saskatchewan (Dodd and Coupland 1966). However, it has very specific habitat needs occurring on the exposed mud of alkali flats and there may be less than 50 occurrences rangewide (Ungar 1974c).

Scirpus nevadensis

Nevada bulrush

Preliminary Rank: S3

This community is described by Wallis (1990) as occurring generally within the Grassland and Parkland Regions of Alberta on sandy saline shores of emergent marshes. The structure, percent cover and variability of this community are not discussed in the literature. Scirpus nevadensis is considered uncommon and usually occurs with very open growth in the emergent marshes of the Grassland and Parkland regions. It is restricted to saline shores and a few sand plain landscapes, however, in certain areas it may form extensive stands (Wallis 1990, C. Wallis pers comm.) and is found as far south as Texas (Moss 1983). The occurrence of this species as a community type is not well documented, but it is restricted in extent given its saline habitat requirements.

Scirpus nevadensis - (Triglochin maritima)

Nevada bulrush - (Common cattail)

Preliminary Rank: S2S3

This community is described by Wallis (1990) as occurring generally within the Grassland and Parkland Regions of Alberta on sandy saline shores of emergent marshes. The structure, percent cover and variability of this community are not discussed in the literature. Scirpus nevadensis is considered uncommon and usually occurs with very open growth in the emergent marshes of the Grassland and Parkland regions. This is a localized community type confined to a few sand plain landscapes in Alberta; the 

Triglochin component appears to be the rare feature (C. Wallis pers comm.) and the diagnostic component that differentiates it from the Scirpus nevadensis community described above. This community is included on the Alberta Plant Community Tracking List (Allen 2001) and is ranked S1S2 therein.

\section{Suaeda calceoliformis \\ Western sea blight \\ Preliminary Rank: S5}

This community is described by Wallis (1990) as occurring generally within the Grassland and Parkland Regions of Alberta as a hypersaline emergent marsh dominated by $C$. calceoliformis with a cover of $<25 \%$ at the edge of non-vegetated saline wetlands. Common associated species are Chenopodium rubrum, Chenopodium salinum, Puccinellia nuttalliana, Salicornia europaea, Triglochin maritima, and Scirpus pungens. On the upslope side the community grades into grasslands. This community is considered as common around sloughs and saline shores throughout the Grassland and Parkland regions (C. Wallis pers comm.). Because it is only documented once in the literature an assessment of variability between occurrences is not possible.

\section{Triglochin maritima}

Seaside arrow grass

Preliminary Rank: S2?

This community is described by Wallis (1990) as occurring generally within the Grassland and Parkland Regions of Alberta as a saline emergent marsh characteristic of very fine sand to sandy clay saline meadow soils. It is typified by a band of pure Triglochin maritima with a basal cover $<20 \%$. The most prevalent associated plants include Hordeum jubatum, Distichlis stricta, Ranunculus cymbalaria, Chenopodium rubrum and Suaeda calceoliformis. This community also occurs in active springs in Alberta but is very restricted in area extent (C. Wallis pers comm.). The plant species Triglochin maritima is common in saline depressions in Alberta (Moss 1983, Johnson et al. 1995), British Columbia (Parish et al. 1996) and Saskatchewan (Dodd and Coupland 1966) and the community type is described from north-central United States (e.g. Montana; Heidel et al. 2000). This community is currently on the ANHIC plant community tracking list (Allen 2001) and ranked S2?.

Elsewhere, this community corresponds to the $T$. maritimus community described from Montana by Heidel et al. (2000); a community present on finetextured soils of saline and subsaline lakes, seeps and associated inlets. However, a formal comparison of this community with Alberta Parkland types is difficult because cover estimates are not provided by Heidel et al. (2000). 



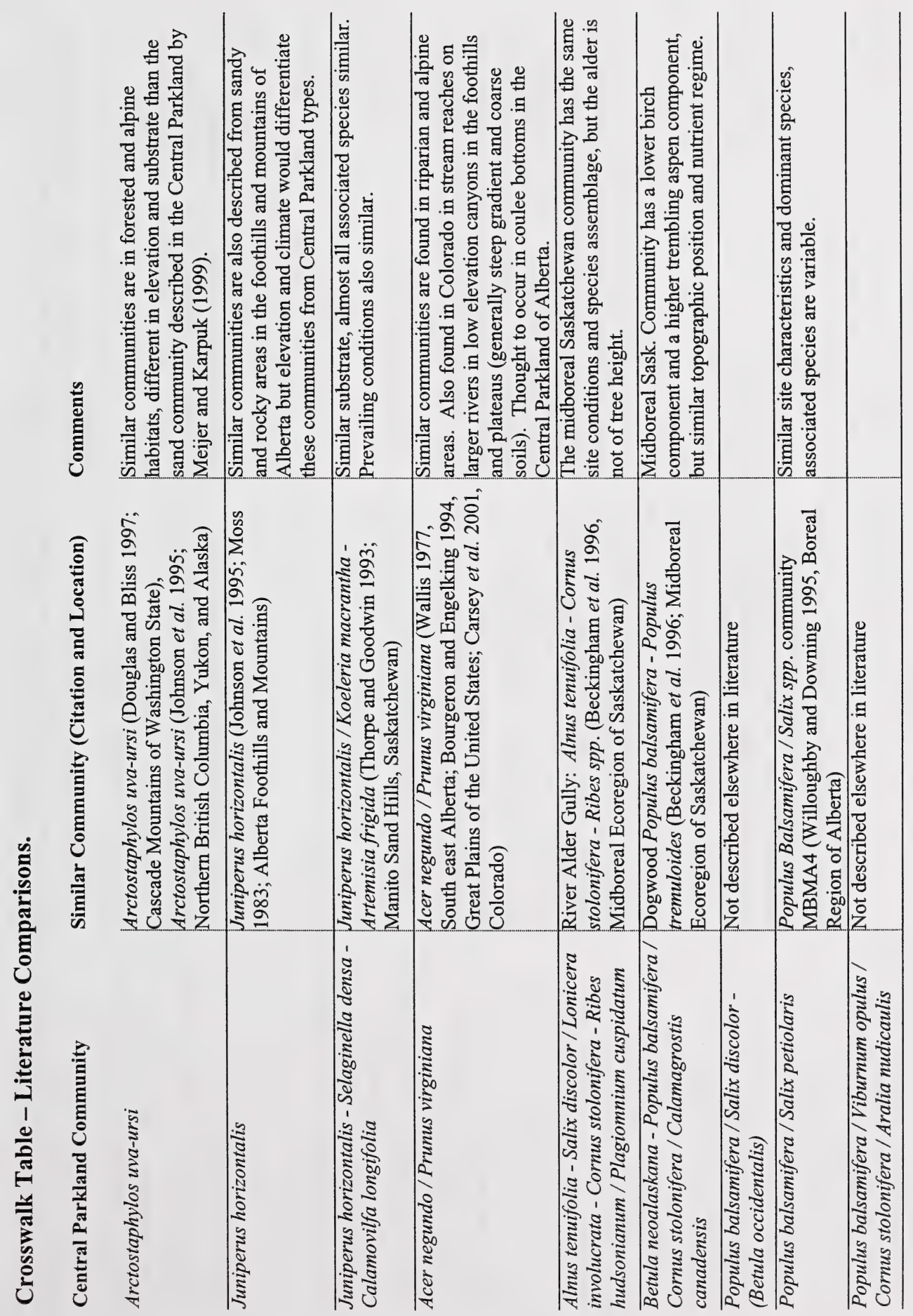





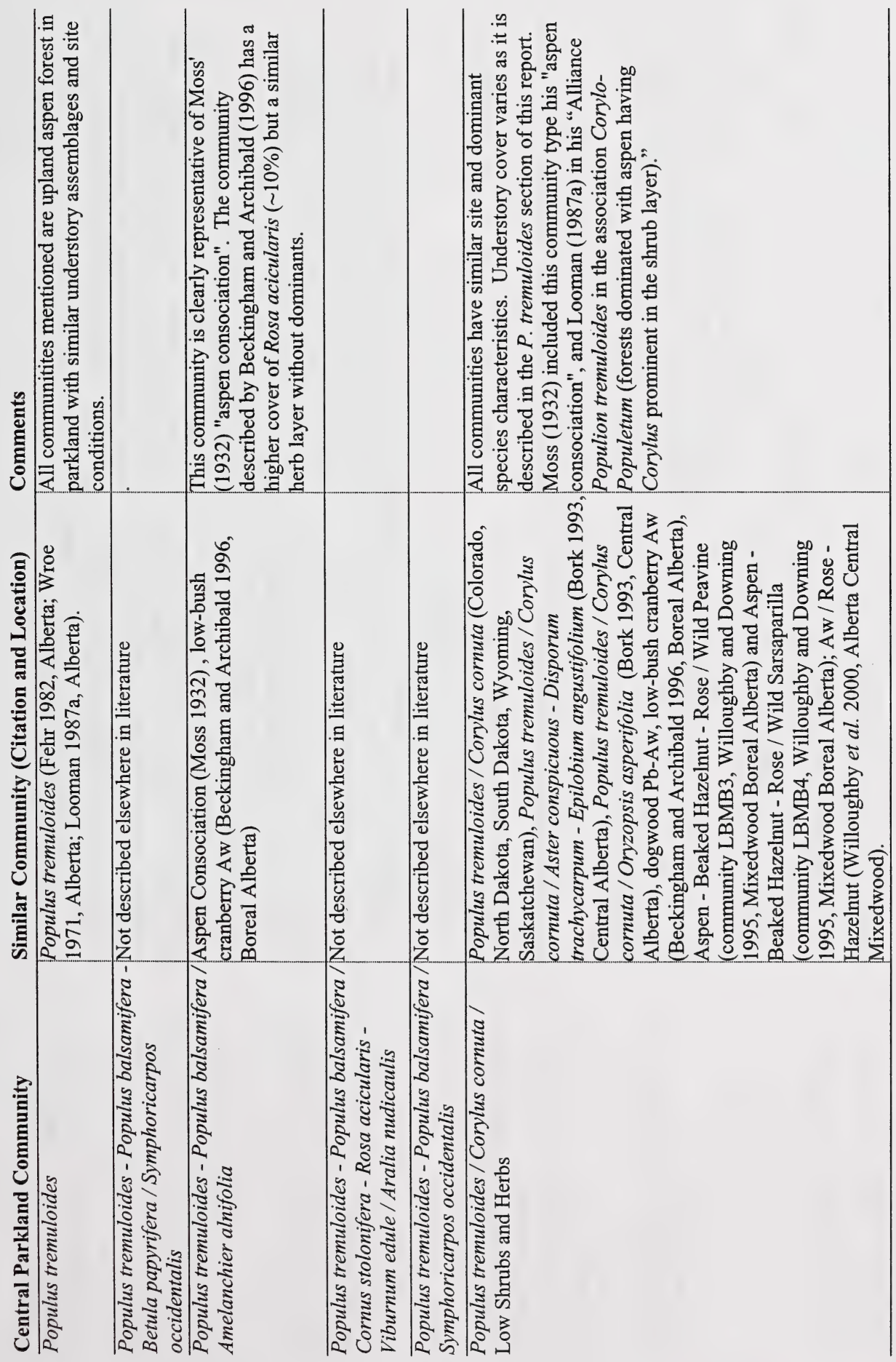





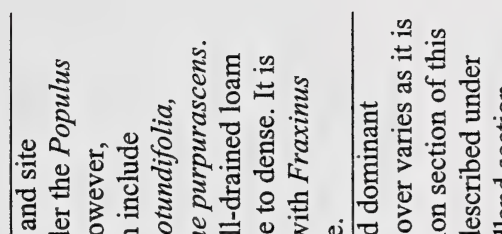

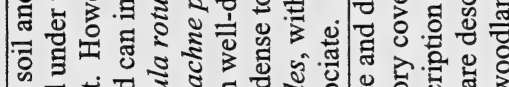

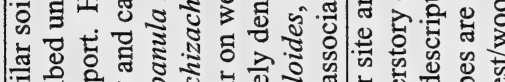

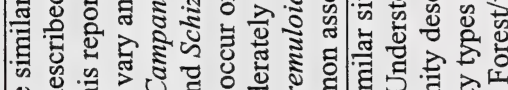
¿ व สู

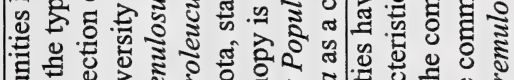
药 ป⿻

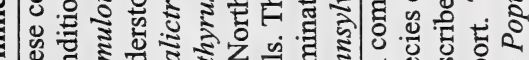

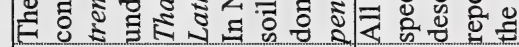

สิ गु)

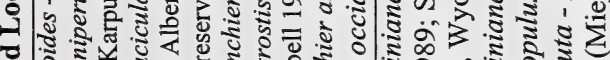
न .

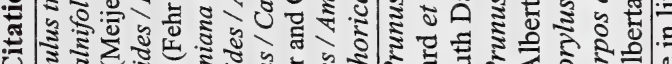
บ

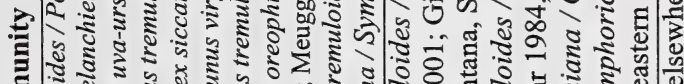
हี

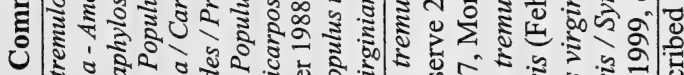

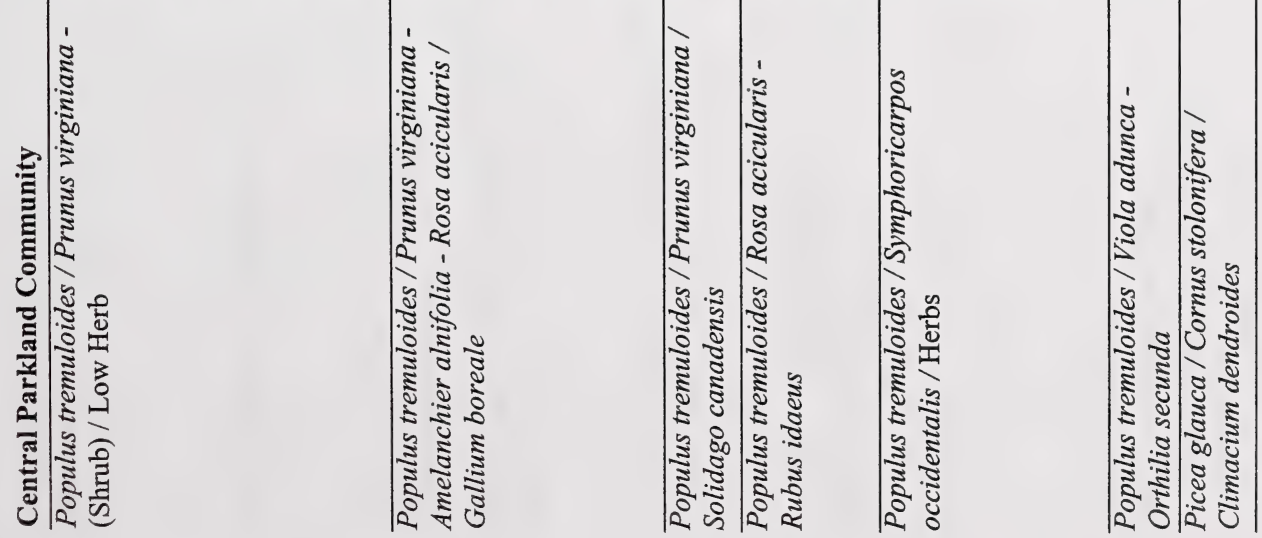





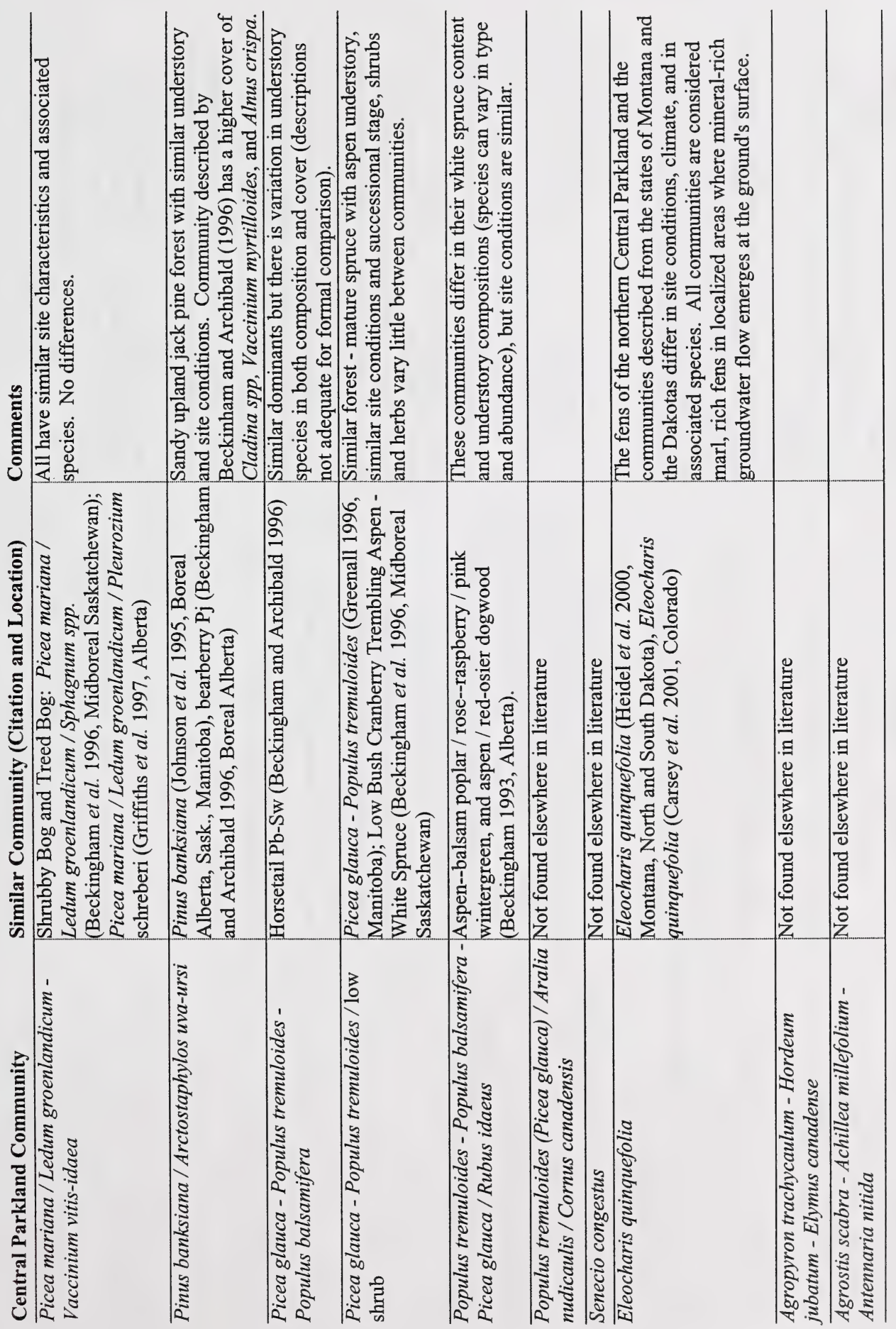





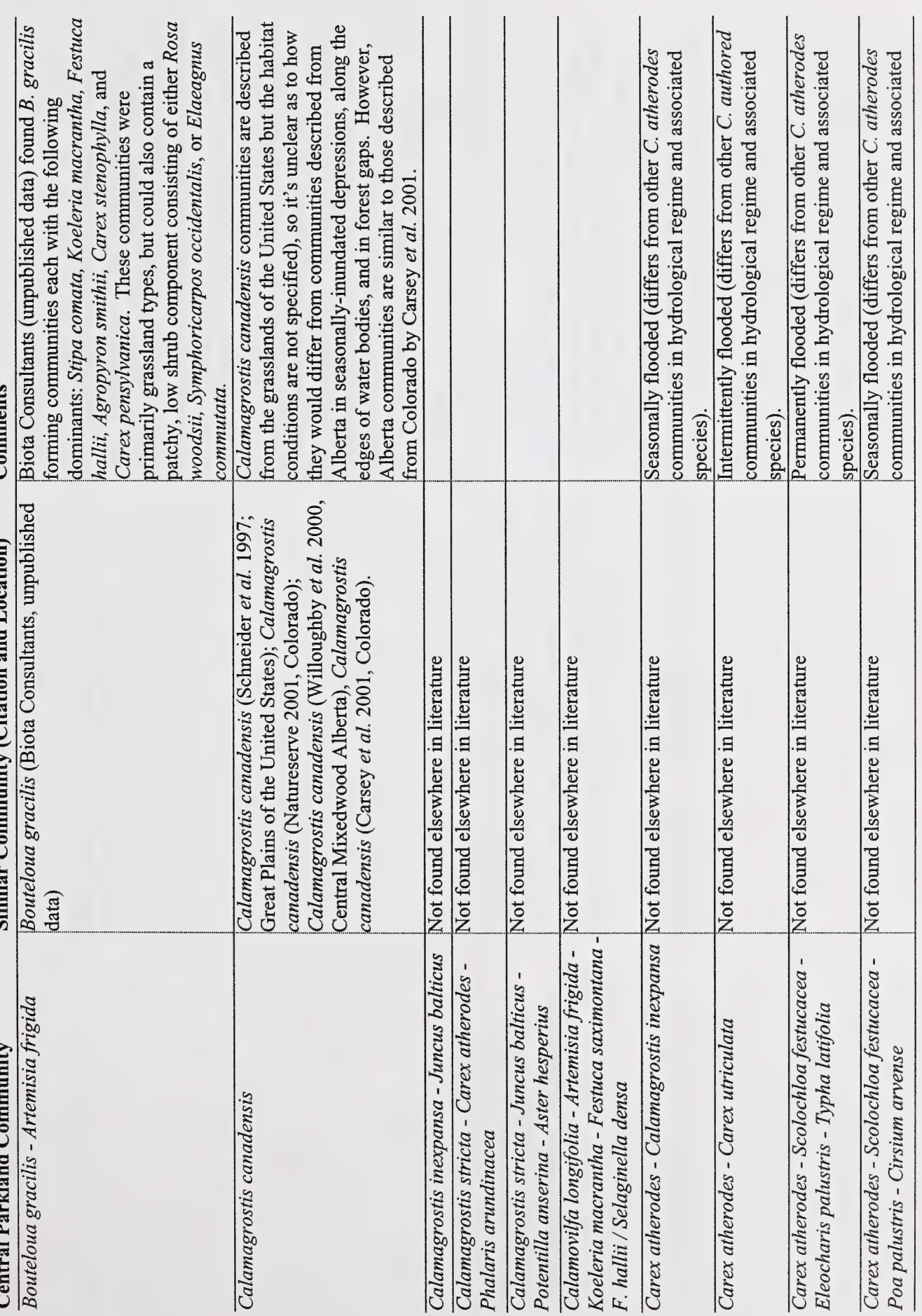





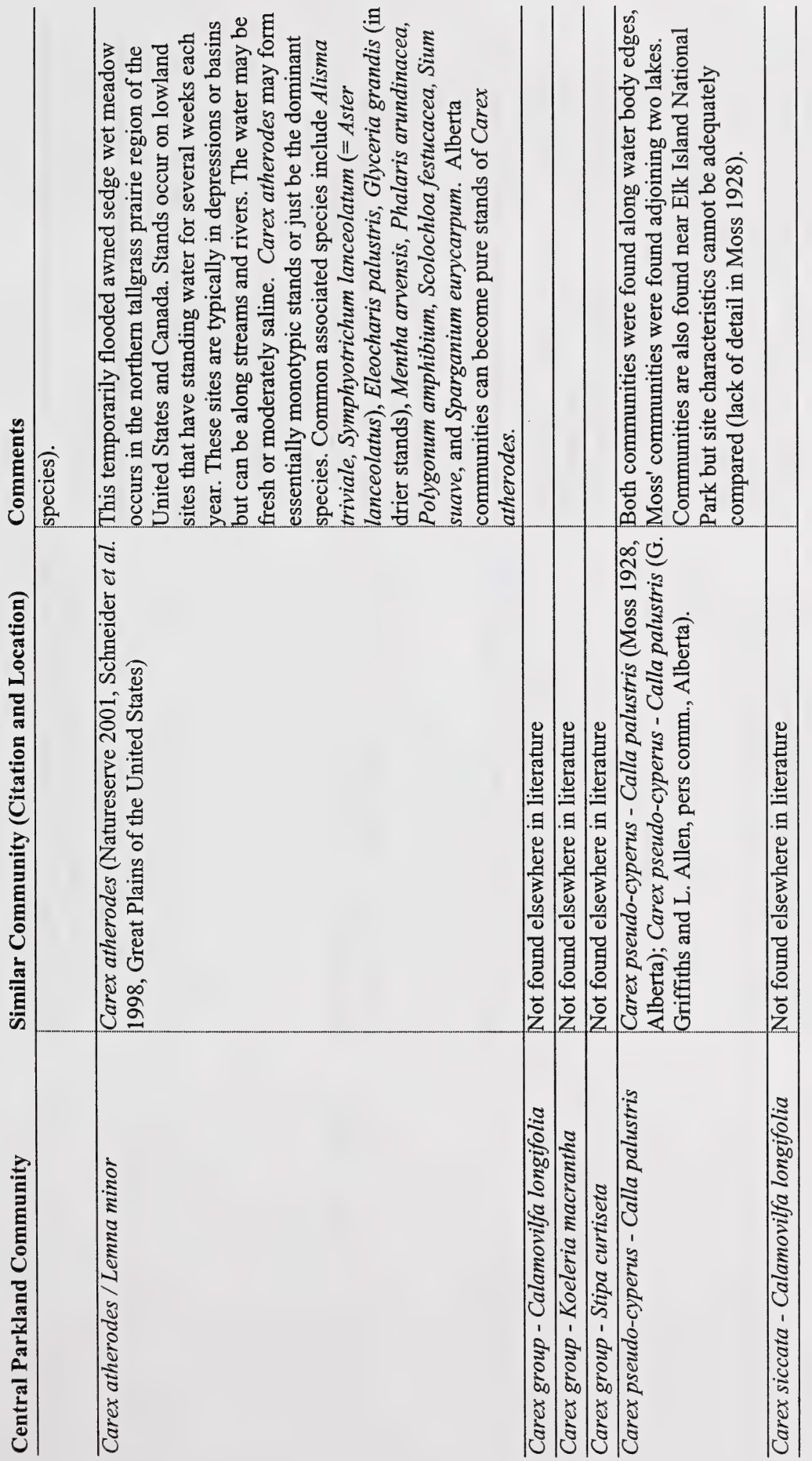




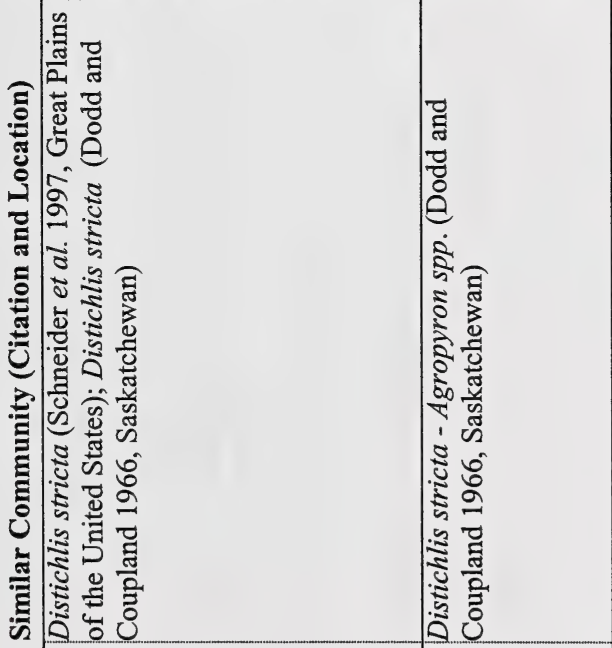

\section{要迹}

i.

2ิ

$\stackrel{8}{8}$

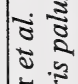

$\frac{1}{2}$

焉

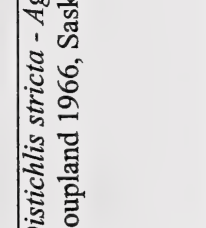

\section{商.}

荧芯

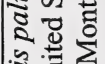

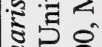

ฏ.

$\frac{\sqrt{x}}{\sqrt{2}}$

范

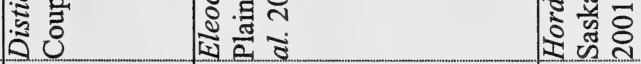





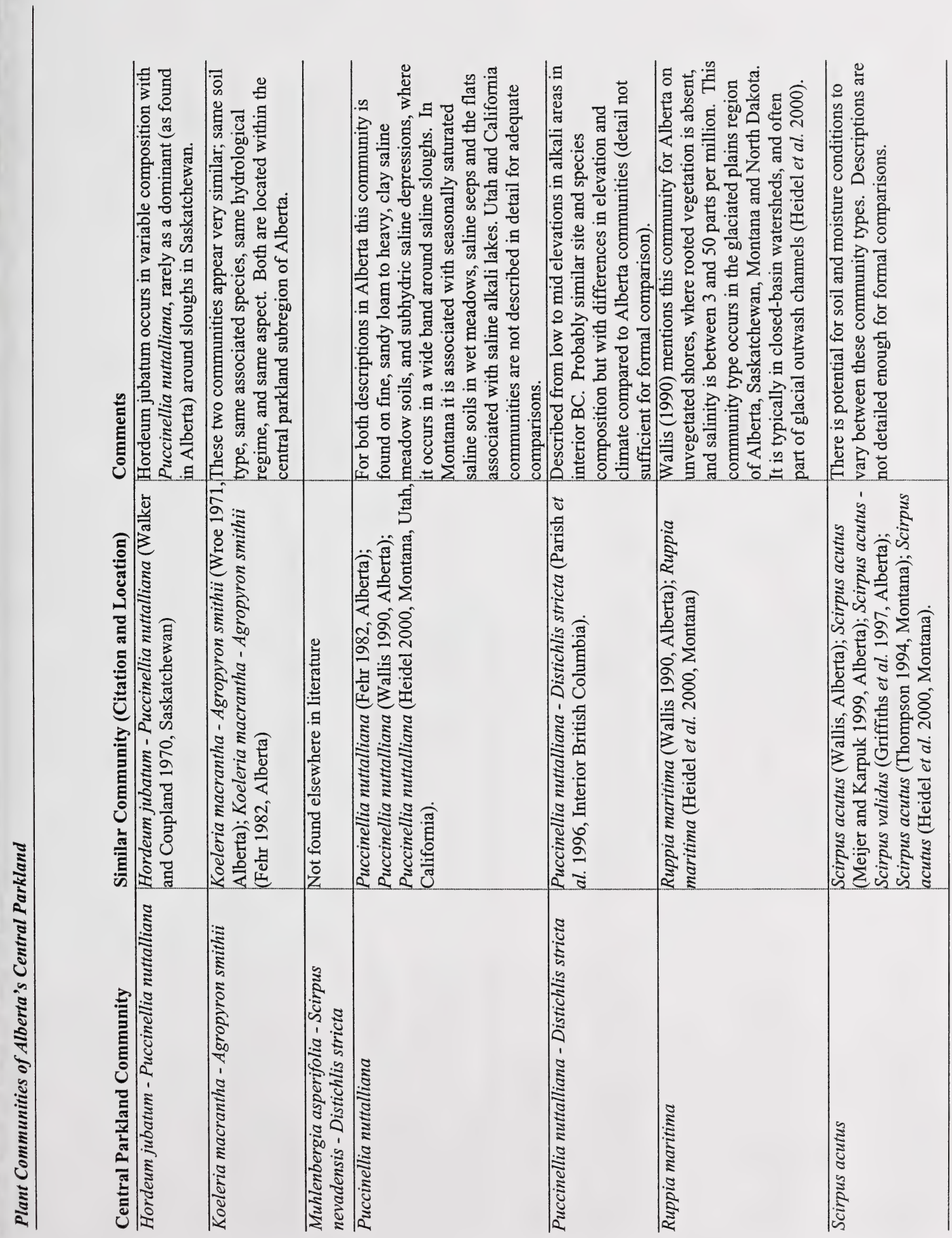





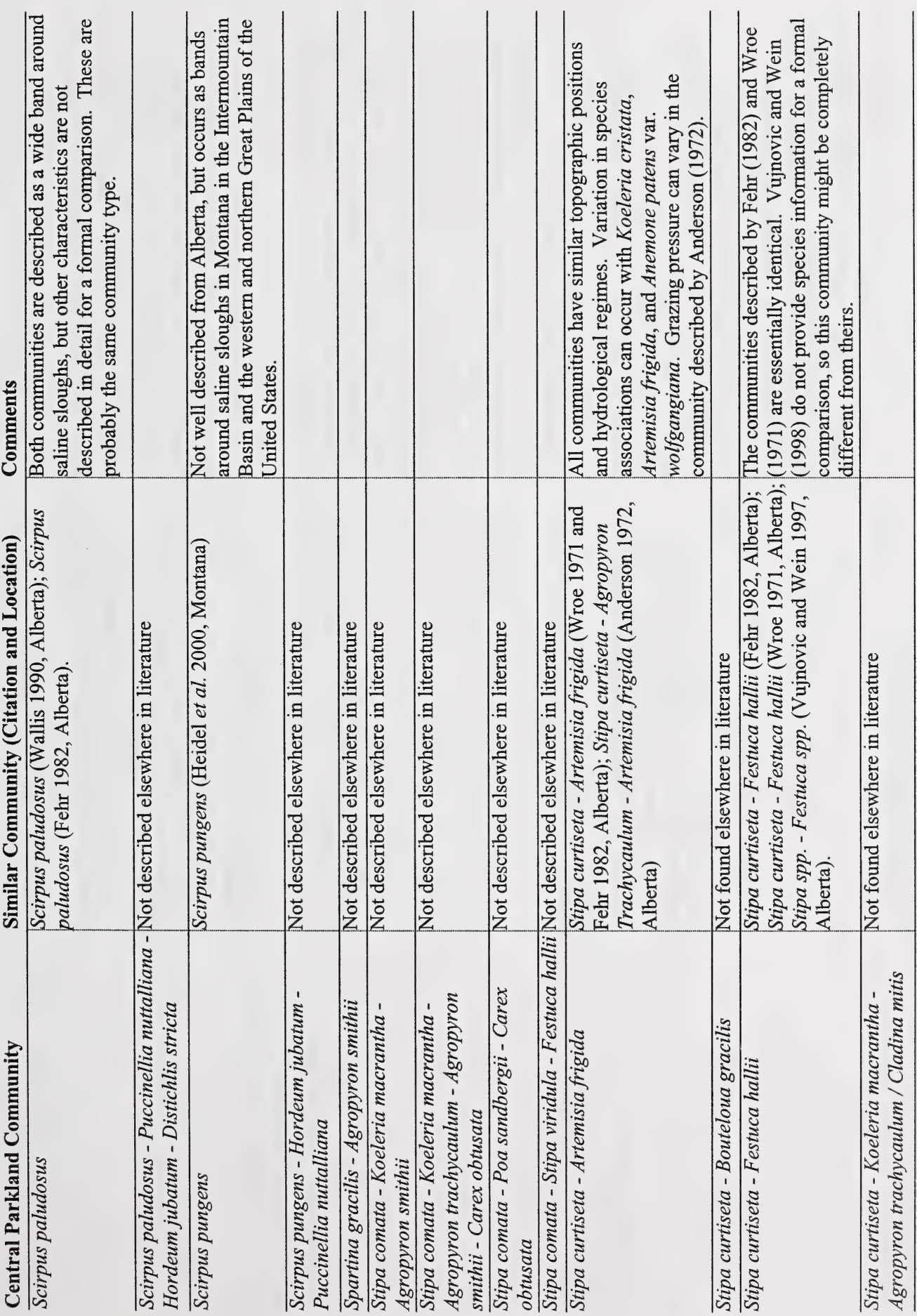





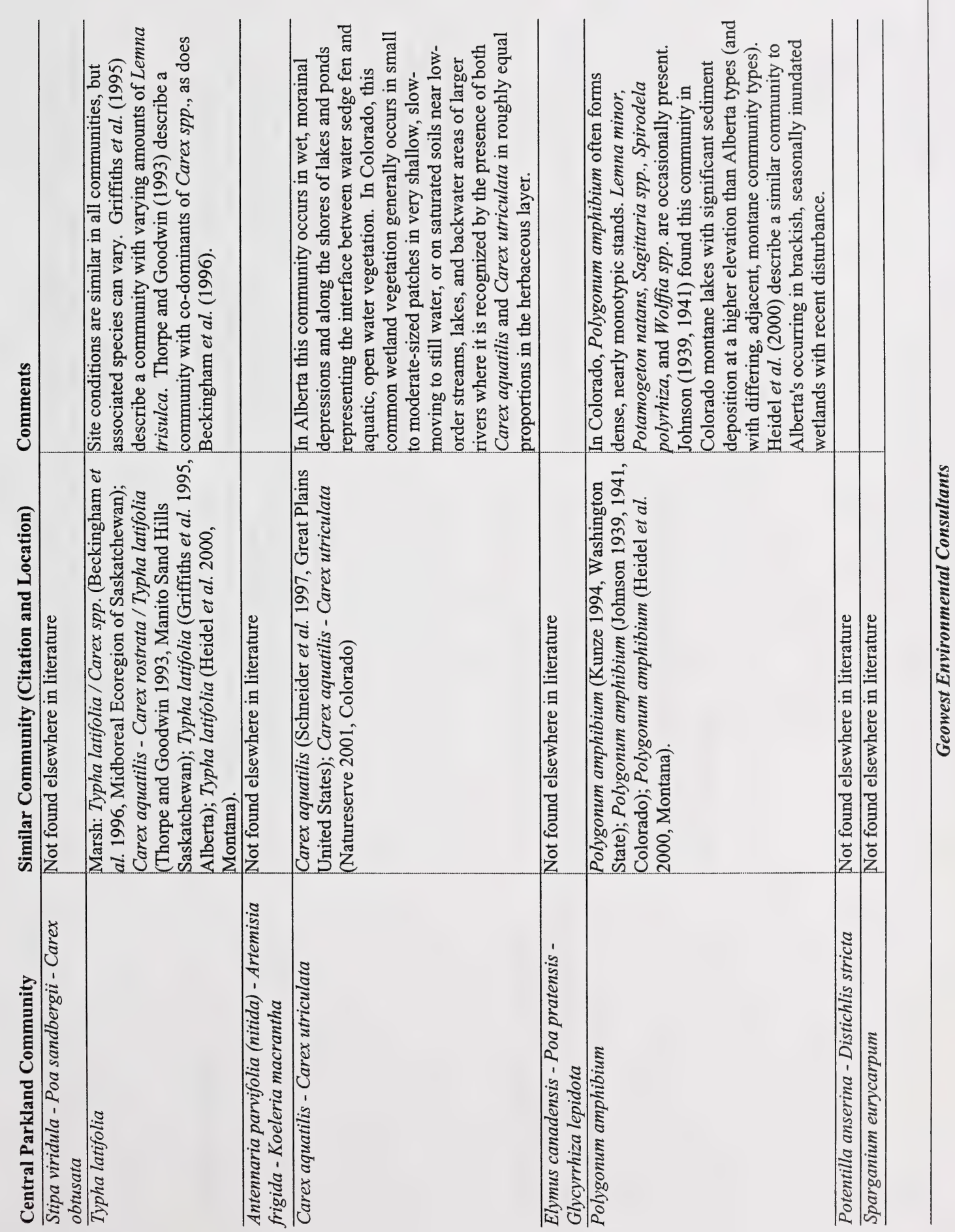





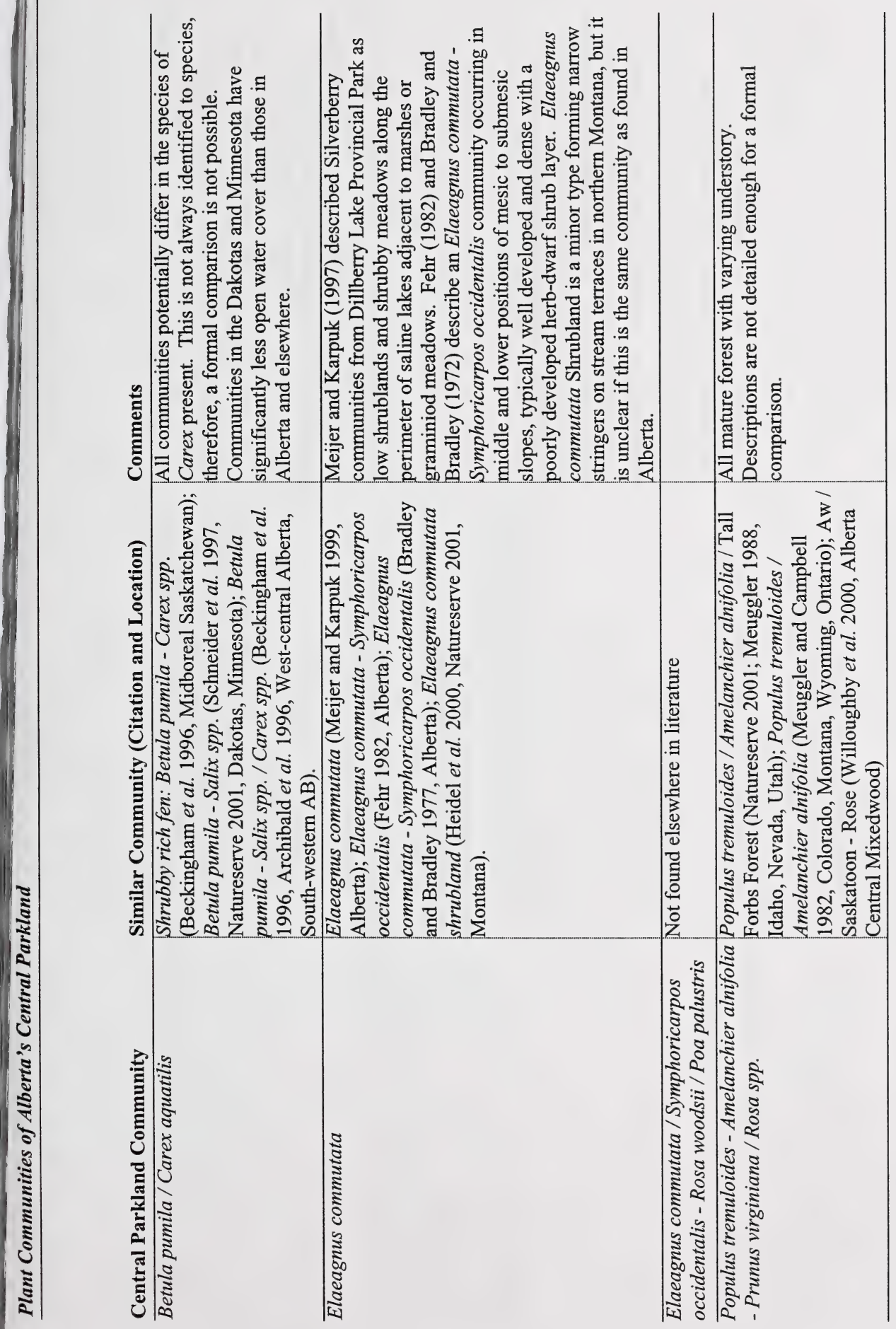





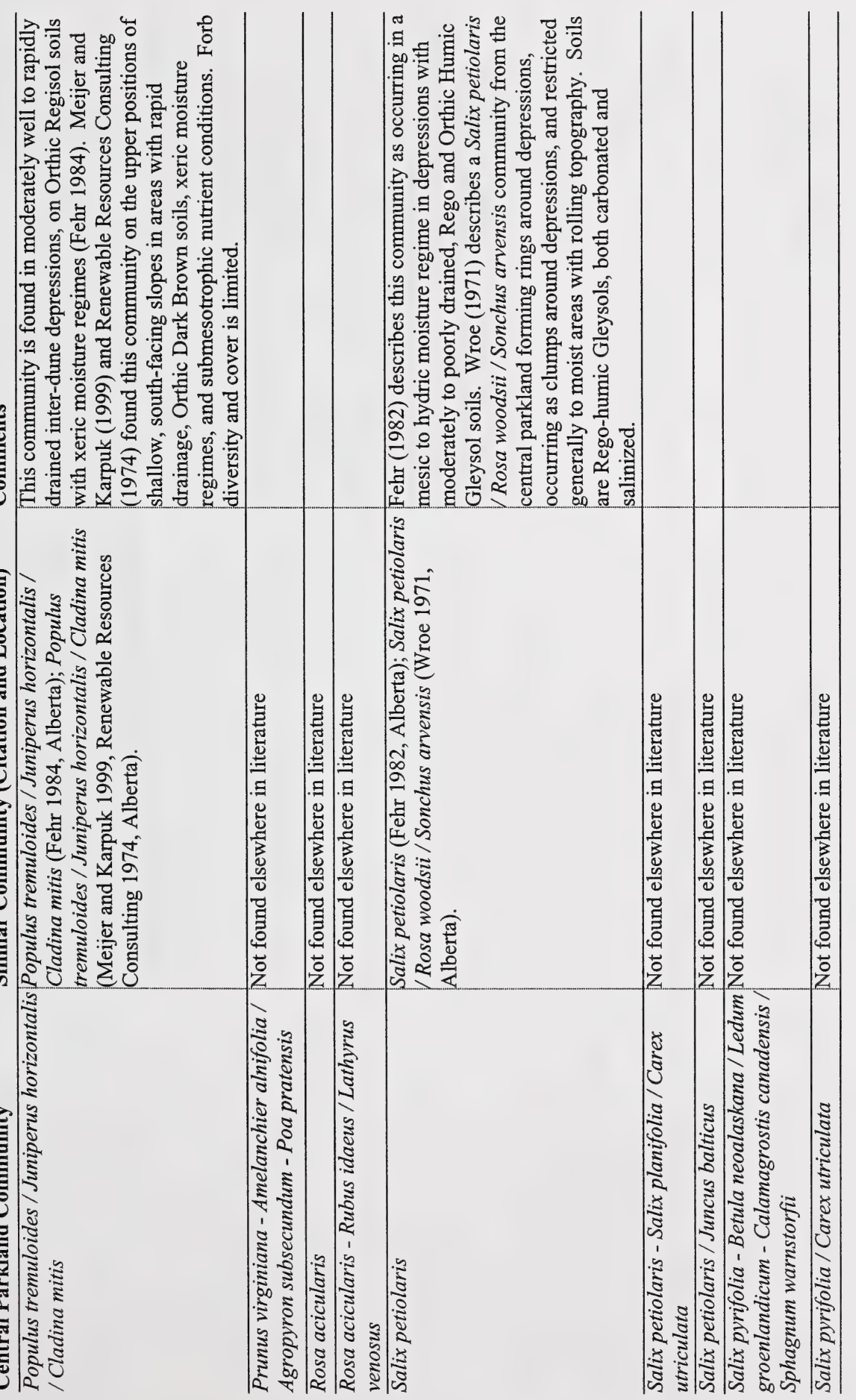





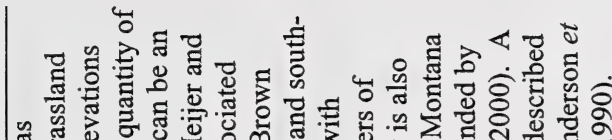

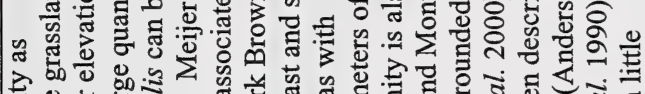

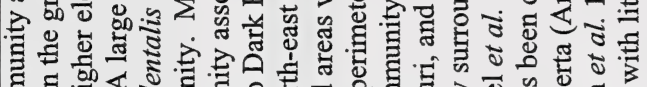

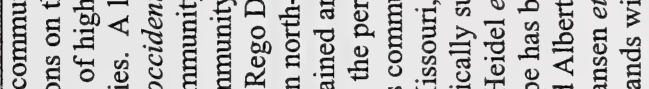
8. 等:

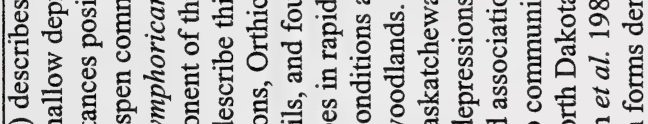

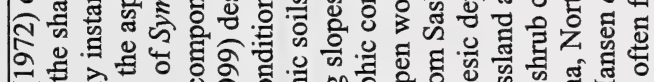

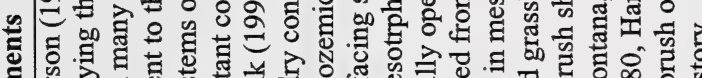

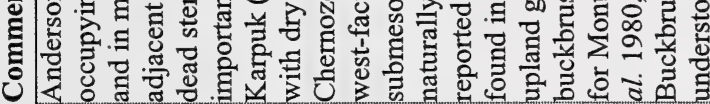
ชํำ

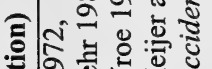
8.

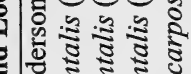
प्रक है है है

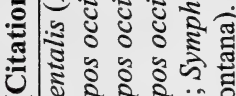

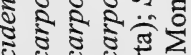

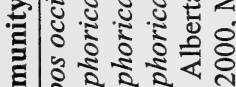

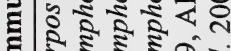
\%

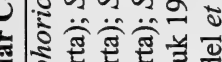
क है

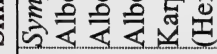





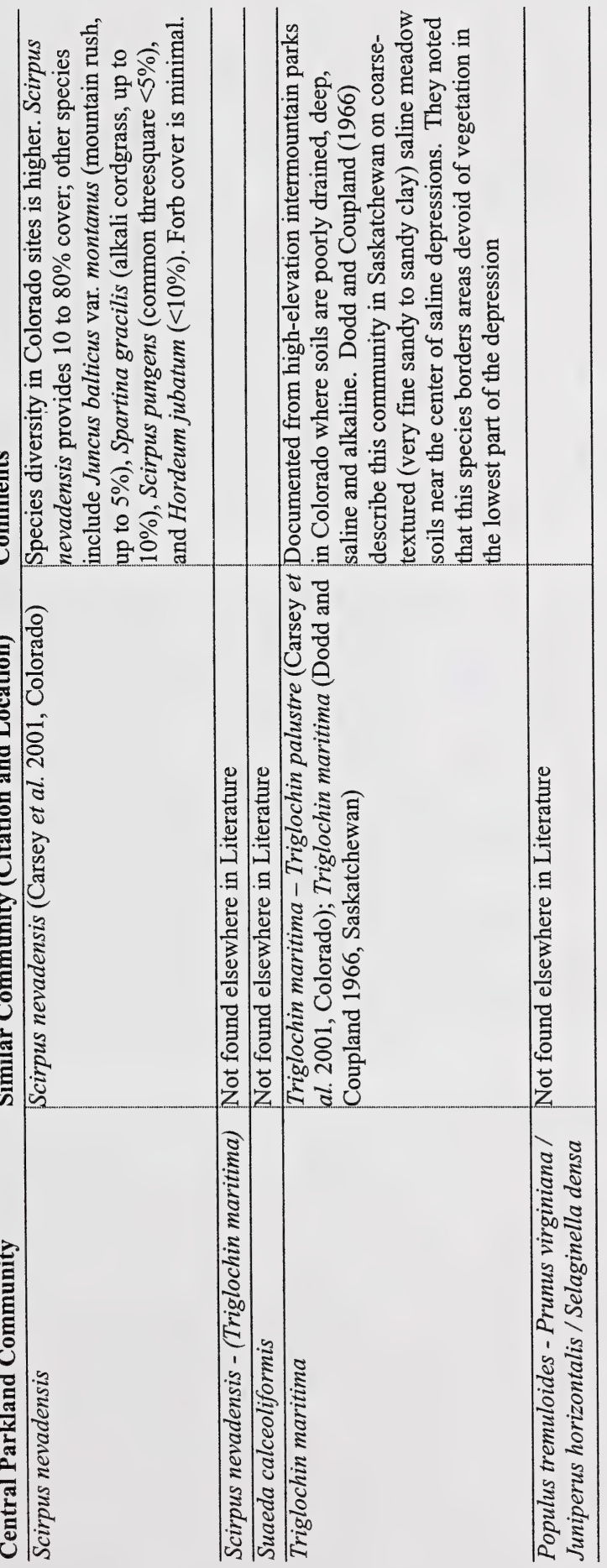





\section{Discussion}

The identification of community types in the Central Parkland Subregion of Alberta has been done primarily through qualitative, descriptive means, and with this type of information it is difficult to determine abundance or ecological effectiveness of described community types. In the literature, community descriptions vary from superficial to detailed, and in most instances there is not enough information to adequately describe community structure, let alone estimate a conservation rank (i.e. distribution and abundance). Several communities found in the Central Parkland Subregion can also be found in higher abundance in grassland, boreal or foothill regions. On a provincial scale, these would be considered without threat, but between natural regions the same community is most likely subject to different microclimates, animal assemblages (e.g. herbivory) and human use, hence serving two different functions on the landscape. It would be a difficult task to determine ecological differences between the same community type across natural regions, but it should be noted that some S5 communities described from the Central Parkland could be very different (through area, edge and species use effects), and serve very different ecological functions relative to similar community types found in other natural regions.

An estimation of patch size to augment measures of occurrence seems critical for an area as fragmented as the central parkland subregion of Alberta. Certainly an aspen forest relegated to marginal substrate or completely fragmented as a fencerow is not comparable to a similar forest type further north. With current information, a rating of S5 for an aspen community described from the Central Parkland Subregion says little about its value as habitat for plant and animal species endemic or specific to this subregion. We found only one source that gave quantitative values on patch size for forest patches in the Central Parkland. Given that the ranking guidelines are based primarily on the number of occurrences, an estimation of patch size, complete with some estimate of variance, seems critical for this process. There is a large body of information on area and edge effects for both plants and animals, something that should not be ignored when considering community "occurrences". These types of spatial data are readily available for other areas of the province and similar techniques should be used in the Central Parkland (e.g. simple GIS AVI polygon mapping).

Community description styles vary considerably between authors. This is to be expected considering the available information spans almost 70 years, and there has not been a standardized sampling method for either qualitative or empirical data collection.

Standardized methods for describing communities are now prevalent (see Grossman et al. 1998), and well-described communities from historical data sets should be revisited in the field to apply these standards. Communities can appear similar in superficial descriptions, but differ markedly in soil type, aspect, and moisture regime for example, information that is currently not readily available in most cases. We caution the reader against information gaps such as these when making conclusions regarding community similarities outlined throughout this report. 

The Central Parkland Natural Subregion of Alberta is the most impacted area of the province, and native plant communities exist only in remnants. In fact, upwards of $95 \%$ of the area is cultivated and converted for human agricultural, urban and industrial use. It would appear that a vegetation survey and digital mapping exercise locating native plant community remnants would not be a large undertaking across $5 \%$ of the region, even if these were evenly or randomly distributed. The amount of change on this landscape, the change in agricultural land boundaries, gas pipelines, highways and new urban developments makes the use and reliability of historical plant community descriptions tenuous. This report makes extensive use of historical community accounts, some dating back to the early 1900's. Our effort here represents a preliminary estimation of what is potentially still in the Central Parkland and, as it is based on existing literature, is most certainly not complete or necessarily representative of the current state of Central Parkland plant community diversity.

Not all formation classes are represented in this report. We found information on Forest/Woodland, Shrubland, Dwarf-shrubland, Herbaceous, and Sparse vegetation; we did not find information on nonvascular communities. Lichens and particularly mosses form important components of vascular-dominated communities in this region and undoubtedly form independent communities that would be classified into the nonvascular formation class; particularly in areas of the Central Parkland where exposed rock or glacial erradics are common (e.g. kame moraines). These community types should be considered in future surveys of this area.

\section{Personal Communications}

Lorna Allen, Biodiversity Biologist, Alberta Community Development, Parks and Protected Areas, Operations and Resource Management Branch, Government of Alberta, Edmonton Alberta.

Dr. Graham Griffiths, Biologist, Sherwood Park, Alberta.

Harry Loonen, Public Lands Specialist, Wainwright Public Lands Division, Sustainable Resource Development, Government of Alberta, Wainwright, Alberta.

Dr. Cliff Wallis, Biologist, Cottonwood Consultants, Calgary, Alberta.

Anne Holcroft Weerstra, Biologist, Biota Consultants, Cochrane, Alberta.

\section{Literature Cited}

Acharya, S.N., C.B. Chu, and R.Hermesh. 1989. Effects of population, environment and their interaction on Saskatoon berry (Amelanchier alnifolia Nutt.) seed germination. Can. J. Bot. 62:858-864.

Acton, D.F. G.A. Padbury and C.T. Stushnoff. 1998 The Ecoregions of Saskatchewan. Regina: Canadian Plains Research Center. 

Agee, J.K. 1993. Fire ecology of Pacific Northwest forests. Island Press. Washington, D.C. 493 pp.

Alberta Environmental Protection. 1994b. Alberta protected areas system analysis (1994). Report 3: Revised by P. Achuff, December 7, 1994, Edmonton, Alberta.

Alberta Environmental Protection. 1997. The parkland natural region of Alberta. One of a series of reports prepared for the Special Places 1000 Provincial Coordinating Committee. Alberta Environmental Protection, Natural Resource Service, Recreation and Protected Areas Division, Natural Heritage Planning and Evaluation Branch, Edmonton, Alberta.

Allen, L. 2000. Alberta Natural Heritage Information Center Preliminary Plant Community Tracking List, Alberta Community Development, Edmonton, Alberta.

Anderson, M.L. 1972. The effect of fire on grasslands in the Alberta Aspen Parkland. Master of Science Thesis. Dept. of Plant Science, University of Alberta, Edmonton, Alberta.

Anderson, H.G. and A.W. Bailey 1980. Effects of annual burning on grassland in the aspen parkland of east-central Alberta. Canadian Journal of Botany. 58: 985-996.

ANHIC, 2001. Alberta Natural Heritage Information Center Vascular Plant Tracking List, Updated March 19, 2001. Alberta Sustainable Resource Development, Public Lands Division, Edmonton, Alberta. Available on-line at http://www.cd.gov.ab.ca/preserving/parks/anhic/vastrak.asp

Baker, W. L. 1984a. A preliminary classification of the natural vegetation of Colorado. Great Basin Naturalist 44(4):647-676.

Baker, W. L., and S. C. Kennedy. 1985. Presettlement vegetation of part of northwestern Moffat County, Colorado, described from remnants. Great Basin Naturalist 45(4):747-777.

Beckingham, J. 1993. Ecosystem associations of northern Alberta. Alberta Forest Service, Timber Management Branch, Edmonton, AB.

Beckingham, J.D., D.G. Nielsen, and V.A. Futoransky. 1996. Field guide to ecosites of the mid-boreal ecoregions of Saskatchewan. Canadian Forest Service, Northwest Region, Northern Forestry Center, Edmonton, Alberta.

Bird, R.D. 1961. Ecology of the aspen parkland of western Canada in relation to land use. Canada Agriculture Publication 1066 (II), I, X, 155p. 

Bourgeron, P. S., and L. D. Engelking, editors. 1994. A preliminary vegetation classification of the western United States. Unpublished report. The Nature Conservancy, Western Heritage Task Force, Boulder, CO. 175 pp. plus appendix.

Bradley, Lynn and Cheryl Bradley. 1977. Aspen Groveland Resource Assessment: Neutral Hills Area. Parks Planning and Design Branch, Alberta Recreation, Parks and Wildlife, Edmonton, Alberta.

Budd, A.C. 1987. Budd's flora of the Canadian prairie provinces. Research Branch Agriculture Canada. Publ. 1662. Ottawa, ON.

Carsey, K., D. Cooper, K. Decker, and G. Kittel. 2001. Comprehensive statewide wetlands classification and characterization; Wetland plant associations of Colorado. Prepared for Colorado Department of Natural Resources, Colorado Natural Heritage Program, College of Natural Resources, Fort Collins, CO.

Coupland, R.T. and T.C. Brayshaw 1953. The fescue grassland in Saskatchewan. Ecology. 34(2): 386-405.

Crack, S., and B.J. Danielson. 1974. An Ecological Study of Beauvais Lake Provincial Park. Alberta Dep't of Lands and Forests.

Dodd, J.D. and R.T. Coupland. 1966. Vegetation of saline areas in Saskatchewan. Ecology. 47:958-967.

Douglas, G. W., and L. C. Bliss. (1977). Alpine and high subalpine plant communities of the North Cascades Range, Washington and British Columbia. Ecological Monographs 47:113-150

Driscoll, R. S., D. L. Merkel, D. L. Radloff, D. E. Snyder, and J. S. Hagihara. 1984. An ecological land classification framework for the United States. USDA Forest Service. Miscellaneous Publication No. 1439. Washington, DC. 56 pp.

Fehr, Alan W. 1982. The Candidate Rumsey Ecological Reserve: A Biophysical Inventory. Alberta Energy and Natural Resources, Public Lands Division, Edmonton, Alberta.

Fehr, Alan W. 1984. Wainwright Study Area: A Biophysical Inventory. Alberta Energy and Natural Resources, Public Lands Division, Edmonton, Alberta.

Gersib, R. A., and G. Steinauer. 1991. A biological inventory and general assessment of eastern Nebraska saline wetlands in Lancaster and southern Saunders counties. Transactions of the Nebraska Academy of Sciences, Volume VIII:37-44. 


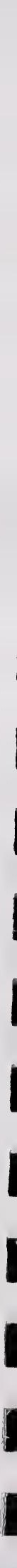


Girard, M. M., H. Goetz, and A. J. Bjugstad. 1989. Native woodland habitat types of southwestern North Dakota. USDA Forest Service, Rocky Mountain Forest and Range Experiment Station. Research Paper RM-281. Fort Collins, CO. 36 pp.

Greenall, J. A. 1996. Manitoba's terrestrial plant communities. Manitoba Conservation Data Center MS Report 96-02.

Griffiths, D.E., and G.C.D. Griffiths. 1987a. Biophysical survey of Sylvan Lake Natural Area, Alberta. Public Lands Division, Alberta Forestry, Lands and Wildlife, Edmonton, Alberta.

Griffiths, D.E., and G.C.D. Griffiths. 1987b. Biophysical survey of Bilby Natural Area. Alberta Forestry, Lands and Wildlife Information Center, Edmonton, Alberta.

Griffiths, C.D., D.E. Griffiths, and W.S. Taylor. 1996. Biophysical and significant areas inventory of the Lister Lake study area (1995). Report prepared for Resource Data Division, Alberta Environmental Protection, Edmonton, Alberta.

Griffiths, G.C.D., D.E. Griffiths, and R. Priddle. 1997. Floristic and rare plant survey of the Blackfoot Provincial Recreation Area (1996). Natural resource service/Parks, Parkland Region, Alberta Environmental Protection, Rimbey, Alberta.

Grossman, D.H., K.L. Goodin, and C.L. Reuss. 1994. Rare plant communities of the conterminous United States, an initial survey. The Nature Conservancy, Arlington, VA. 619p.

Grossman, D.H., D. Faber-Langendoen, A.S. Weakley, M. Anderson, P. Bourgeron, R. Crawford, K. Goodin, S. Landaal, K. Metzler, K. Patterson, M. Pyne, M. Reid, and L. Sneddon. 1998. International classification of ecological communities: terrestrial vegetation of the United States. Volume I. The National Vegetation Classification System: development, status, and applications. The Nature Conservancy, Arlington, Virginia, USA.

Hansen, P, K. Boggs, R. Pfister, and J. Joy. 1990. Classification and management of riparian and wetland sites in central and eastern Montana. Missoula, MT: University of Montana, School of Forestry, Montana Forest and Conservation Experiment Station, Montana Riparian Association. 279 p.

Hansen, P. L. 1985. An ecological study of the vegetation of the Grand River/Cedar River, Sioux, and Ashland districts of the Custer National Forest. Unpublished dissertation. South Dakota State University. 257 pp.

Hansen, P. L., and G. R. Hoffman. 1988. The vegetation of the Grand River/Cedar River, Sioux, and Ashland districts of the Custer National Forest: A habitat type classification. USDA Forest Service, Rocky Mountain Forest and Range Experiment Station. General Technical Report RM-157. Fort Collins, CO. 68 pp. 

Hansen, P. L., G. R. Hoffman, and A. J. Bjugstad. 1984. The vegetation of Theodore Roosevelt National Park, North Dakota: A habitat type classification. USDA Forest Service, Rocky Mountain Forest and Range Experiment Station. General Technical Report RM-113. Fort Collins, CO. 35 pp.

Hansen, P. L., R.D. Pfister, K. Boggs, J. Cook, J. Joy, and D.K Hinckley. 1995. Classification and management of Montana's riparian sites. Montana Forest and Conservation Experiment Station, School of Forestry, Misc. Pub. No. 43. University of Montana, Missoula. 646 pp.

Hansen, P.L. and G.R. Hoffman. 1988. The vegetation of the Grand River/Cedar River, Sioux, and Ashland Districts of the Custer National Forest: a habitat type classification. Gen. Tech. Rep. RM-157. Fort Collins, CO: U.S. Department of Agriculture, Forest Service, Rocky Mountain Forest and Range Experiment Station. 68 p.

Hansen, P.L., G.R. Hoffman, and A.J. Bjugstad. 1984. The vegetation of Theodore Roosevelt National Park, North Dakota: a habitat type classification. Gen. Tech. Rep. RM-113. Fort Collins, CO: U.S. Department of Agriculture, Forest Service, Rocky Mountain Forest and Range Experiment Station. 35 p.

Hanson, H. C., and W. Whitman. 1938. Characteristics of major grassland types in western North Dakota. Ecological Monographs 8:58-114.

Hardy and Associates 1986. Ecological land classification of Elk Island National Park. Hardy and Associates (1978) Ltd. Calgary, Alberta.

Heidel, B., S. V. Cooper, and C. Jean. 2000. Plant species of special concern and plant associations of Sheridan County, Montana. Report to the U.S. Fish and Wildlife Service. Montana Natural Heritage Program, Helena. 22 pp. plus appendices.

Hilton, J.E. 1970. Forage production and utilization in the aspen parkland of Alberta following aerial application of 2,4-D and 2,4,5-T. MSc Thesis, Department of Plant Science, University of Alberta, Edmonton, Alberta.

Hirsch, K. J. 1985. Habitat type classification of grasslands and shrublands of southwestern North Dakota. Ph.D. thesis. North Dakota State University, Fargo.

Hoffman, G. R., and R. R. Alexander. 1987. Forest vegetation of the Black Hills National Forest of South Dakota and Wyoming: A habitat type classification. USDA Forest Service, Rocky Mountain Forest and Range Experiment Station. Research Paper RM-276. Fort Collins, CO. 48 pp. 

IISD. 1994. Sustainability of Canada's agri-food system - a prairie perspective. Published by the International Institute for Sustainable Development (IISD) for the Faculty of Agriculture and Food Studies, University of Manitoba.

Johnson, K. R. 1939. Plant ecology of northwestern Colorado lakes and surrounding areas. Unpublished dissertation. University of Colorado, Boulder. 138 pp.

Johnson, K. R. 1941. Vegetation of some mountain lakes and shores in northwestern Colorado. Ecology 22:306-316.

Johnston, B.C. 1987. Plant associations of Region Two: Potential plant communities of Wyoming, South Dakota, Nebraska, Colorado, and Kansas. R2-ECOL-87-2. USDA Forest Service, Rocky Mountain Region. Lakewood, CO. 429 pp.

Johnson, D., L. Kershaw, A. MacKinnon, and J. Pojar. 1995. Plants of the western boreal forest and aspen parkland. Lone Pine Publishing, Edmonton, Alberta.

Kunze, L. M. 1994. Preliminary classification of native, low elevation, freshwater wetland vegetation in western Washington. Washington State Department of Natural Resources, Natural Heritage Program. 120 pp.

Lieffers, V. J. and S. E. Macdonald. 1993. Ecology of and control strategies for Calamagrostis canadensis in boreal forest sites. Can. J. For. Res. 23:2070-2077.

Little, E.L., Jr. 1979. Checklist of United States trees (native and naturalized). Agric. Handb. 541. Washington, DC: U.S. Department of Agriculture, Forest Service. $375 \mathrm{p}$.

Looman, J. 1983. The vegetation of the Canadian provinces IV. The woody vegetation, Part 1. Phytocoenlogia 11:297-330.

Looman, J. 1987a. The vegetation of the Canadian provinces IV. The Woody vegetation, Part 3, Deciduous woods and forests. Phytocoenlogia 15 (1):51-84

Looman, J. 1987b. The vegetation of the Canadian provinces IV. The Woody vegetation, Part 4, Coniferous forests. Phytocoenlogia 15 (3): 289-327.

Lynch, D. 1955. Ecology of the aspen groveland in Glacier County, Montana. Ecological Monographs 25:321-344.

Marschner, F.J. 1974. The original vegetation of Minnesota. A map compiled in 1930 by F. J. Marschner from U.S. General Land Office Survey Notes and published in 1974 under the direction of M.L. Heinselman of the USDA Forest Service. St. Paul, MN: Cartography Laboratory of the Department of Geography, University of Minnesota. 1 map $(1: 500,000)$ and accompanying text. 

Meijer, M. and E. Karpuk. 1999. Dillberry Lake Provincial Park Biophysical Inventory. Resource Data Division, Alberta Environment, Edmonton.

Metcalf, F. P. 1931. Wild duck foods of North Dakota lakes. USDA Tech. Bull. 221. 72 pp.

Miller, John Gage. 1978. An ecological study of creeping juniper (Juniperus horizontalis Moench.) in Montana. Bozeman, MT: Montana State University. 154 p. Thesis.

Mueggler, W. F. 1988. Aspen community types of the Intermountain Region. USDA Forest Service General Technical Report INT-250. Intermountain Research Station, Ogden, UT. $135 \mathrm{pp}$.

Mueggler, W. F., and R. B. Campbell, Jr. 1982. Aspen community types on the Caribou and Targhee national forests in southeastern Idaho. USDA Forest Service, Intermountain Forest and Range Experiment Station. Research Paper INT-294. Ogden, UT. 32 pp.

Moss, E.H. 1928. The vegetation of Alberta II. The swamp, moor and bog forest vegetation of central Alberta. Journal of Ecology 16:19-70.

Moss, E.H., 1932. The vegetation of Alberta. IV. The poplar association and related vegetation of central Alberta. Journal of Ecology 20: 380-415.

Moss, E.H. and J.A. Campbell. 1948. The Fescue Grassland of Alberta. Can. J. of Research. Vol. 25, Sec. C.

Moss, E.H., 1952. Grassland of the Peace River Region, Western Canada. Canadian Journal of Botany Vol. 30: 98-124.

Moss, E.H., 1953. Marsh and bog vegetation in Northwestern Alberta. Canadian Journal of Botany 31:448-470.

Moss, E. H. 1955. The vegetation of Alberta. Botanical Review. 21(9): 493-567.

Moss, E.H. 1983. Flora of Alberta, Second Edition, Revised by J.G. Packer. University of Toronto Press, Toronto.

Mueller, D., R. Bowman, and W. McGinnies. 1985. Effects of tillage and manure on emergence and establishment of Russian Wildrye in a Saltgrass meadow. Journal of Range Management 38:497-500.

NatureServe Explorer: An online encyclopedia of life [web application]. 2001. Version 1.6 . Arlington, Virginia, USA: NatureServe. Available:

http://www.natureserve.org/explorer. 

Pearson Timberline Forestry Consultants 1993. Wainwright dunes ecological reserve vegetation change/disturbance assessment. Prepared for Alberta Environmental Protection, Resource Information Division, Edmonton, Alberta.

Parish, R., R. Coupe, and D. Lloyd (eds.). 1996. Plants of southern interior British Columbia. Lone Pine Publishing, Vancouver, BC.

Pojar, J. 1982. Boreal and Subalpine Grasslands of Northern BC. In Nicholson, McLean \& Baker, ed., Grassland Ecology and Classification Symposium Proceedings June 1982. BC Ministry of Forests. Victoria, British Columbia:249-261.

Polster, D.F., and L.E. Watson. 1979. Vegetation classification and evaluation - Elk Island National Park. Techman Ltd. For Parks Canada. 134p.

Redmann, R.E. \& A.G. Schwarz. 1986. Dry grassland plant communities in Wood Buffalo National Park, Alberta. The Canadian Field Naturalist Vol. 100: 526-532

Remphrey, W. R.; Steeves, T. A.; Neal, B. R. 1983. The morphology and growth of Arctostaphylos uva-ursi (bearberry): an architectural analysis. Canadian Journal of Botany. 61: 2430-2450.

Renewable Resources Consulting Ltd.. 1975. Dillberry Lake - resource inventory and analysis. Prepared for Alberta Provincial Parks, Deptartment of Lands \& Forests, Edmonton, Alberta.

Rintoul, J. 1984. Silver Valley: Biophysical Resource Analysis. Alberta Forestry, Lands and Wildlife, Edmonton, Alberta.

Schneider, R.E., D. Faber-Langendoen, R.C.Crawford, A.S.Weakley. 1997. The Status of Biodiversity in the Great Plains: Great Plains Vegetation Classification. The Nature Conservancy, Great Plains Program. Minneapolis, MN. 75 pp.

Schwarz, A. and R. Wein. 1997. Threatened dry grasslands in the continental Boreal forests of Wood Buffalo National Park. Canadian Journal of Botany 75:13631370.

Severson, Kieth E.; Garrett, E. Chester. 1974. Growth characteristics of bearberry in the Black Hills. Res. Note. RM-254. Fort Collins, CO: U.S. Department of Agriculture, Forest Service, Rocky Mountain Forest and Range Experiment Station. 3 p.

Smith, W.W., and N. Kondla. 1972. An ecological survey of Dry Island Buffalo Jump Provincial Park. Provincial Parks Planning, Department of Lands and Forests, Government of Alberta (Alberta Environment), Edmonton, Alberta. 

Stacey, E.C. 1927. Ecological Studies on the Native Grasses of the Grande Prairie Beaverlodge District. A thesis submitted to the Committee on Graduate Studies of the University of Alberta, Edmonton, Alberta.

Steeves, T.A., M.W. Steeves, and A.R. Olson. 1991. Flower development in Amelanchier alnifolia (Maloideae). Canadian Journal of Botany 69:844-857.

Strong, W.L. 1999. Botanical, Vegetation and Ecological Resource Survey of the proposed Coal Valley II Mine Extension and Subregional Ecosection Classification. Luscar Ltd - Coal Valley Mine, Edson Alberta.

Thilenius, J. F., G. R. Brown, and A. L. Medina. 1995. Vegetation on semi-arid rangelands, Cheyenne River Basin, Wyoming. USDA Forest Service. General Technical Report RM-GTR-263. Rocky Mountain Forest and Range Experiment Station, Fort Collins, CO. 60 pp.

Thompson, W. 1994. Relationship of the national wetlands inventory to an ecological site classification of wetlands in northeast Montana. Masters Thesis. University of Montana, Missoula. $60 \mathrm{pp}$.

Thorpe, J. and R. Godwin. 1993. Vegetation Survey of the Manito Sand Hills. Applied Plant Ecology Section, Saskatchewan Research Council, Publication No. E25501-E-93.

Timoney, K., and A. Robinson. 1998. Floristic, rare plant, and vegetation survey of the blackfoot provincial recreation area uplands (1997-1998). Treeline Ecological Research Report prepared for; Operations, Natural Resources Service Parkland Region, Alberta Environmental Protection, Rimbey, Alberta.

Ungar, I. A. 1974c. Halophyte communities of Park County, Colorado. Bulletin of the Torrey Botanical Club 101:145-152.

United States Department of Agriculture. reprinted 1988. Range plant handbook. Dover ed. Mineola, N.Y.

USFS [U.S. Forest Service]. 1992. Draft habitat types of the Little Missouri National Grasslands. Medora and McKenzie ranger districts, Custer National Forest. Dickinson, ND.

Vujnovic, K. and J. Bentz. 2001. Preliminary classification of native wheat grass (Agropyron spp.) community types in Alberta. Alberta Environment Report for the Alberta Natural Heritage Information Center, Prepared by Geowest Environmental Consultants Ltd., Edmonton, Alberta. 

Vujnovic, K., and R.W. Wein. 1997. An inventory of remnant prairie grasslands within the central parkland natural sub-region of Alberta. Report prepared for Park Services, Alberta Environmental Protection, Edmonton, Alberta.

Wallis, C. 1977. Red Deer River Resource Evaluation - 1977. Alberta Recreation, Parks and Wildlife, Edmonton, Alberta.

Wallis, C. 1990. Reconnaissance survey of saline wetlands and springs in the GrasslandParkland region of Eastern Alberta. World Wildlife Fund, Prairie for Tomorrow, Edmonton, Alberta, Canada.

Weerstra, B.G. and A.C. Holcroft Weerstra. 1998. Preliminary classification of plains rough fescue (Festuca hallii) community types within the central parkland subregion of Alberta. Alberta Natural Heritage Information Center, Alberta Environment, Edmonton, Alberta.

Western Rangeland Consultants Inc. 1999. Mitigation Measures and Further Recommendations for Rare Native Grasslands on the Cochrane Property and Three other adjacent to Highway 43, near Grande Prairie. Alberta Transportation and Utilities, Edmonton, Alberta.

Wheeler, G.W. 1976. Some grassland and shrubland communities in the parklands of Central Alberta. A thesis submitted to the faculty of graduate studies. Department of Plant Science, U of Alberta

Wilkinson, K. 1981. Remnant and Early Settlement Prairies and Solonetzic Soils in the Peace River District. Master's Thesis, Dept. of Biology, University of Calgary.

Willoughby, M. 2000. Guide to range plant community types and carrying capacity for the dry and central mixedwood subregions of Alberta : third approximation. Alberta Environment, Forest Management Division; Alberta Agriculture Food and Rural Development, Public Lands Division, Edmonton, Alberta.

Willoughby, M., and D. Downing. 1995. Deciduous plant communities and carrying capacity for the boreal ecoprovince of Alberta. Alberta Environmental Protection, Edmonton, Alberta.

Wroe., R.A. 1971. Synecology of a Festuca Scabrella Torr. Grassland. Masters Thesis, Department of Plant Science, University of Alberta, Edmonton, Alberta. 

Bibliothèque nationale du Canada |||||||||||||||||||||||||||||||||||||||||||||||||||||||||||||||||||||||||||||||||||||||||||||||||||||||||||||||||||||||||||||| 33286525476574 